Pedagogy and Psychology, VI (70), Issue: 170, 2018

SCIENCE AND EDUCATIQN A NEW RIMIENSIQN

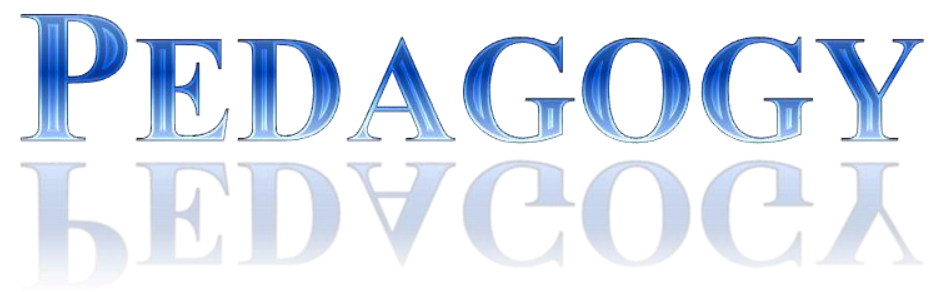

\title{
AND
}
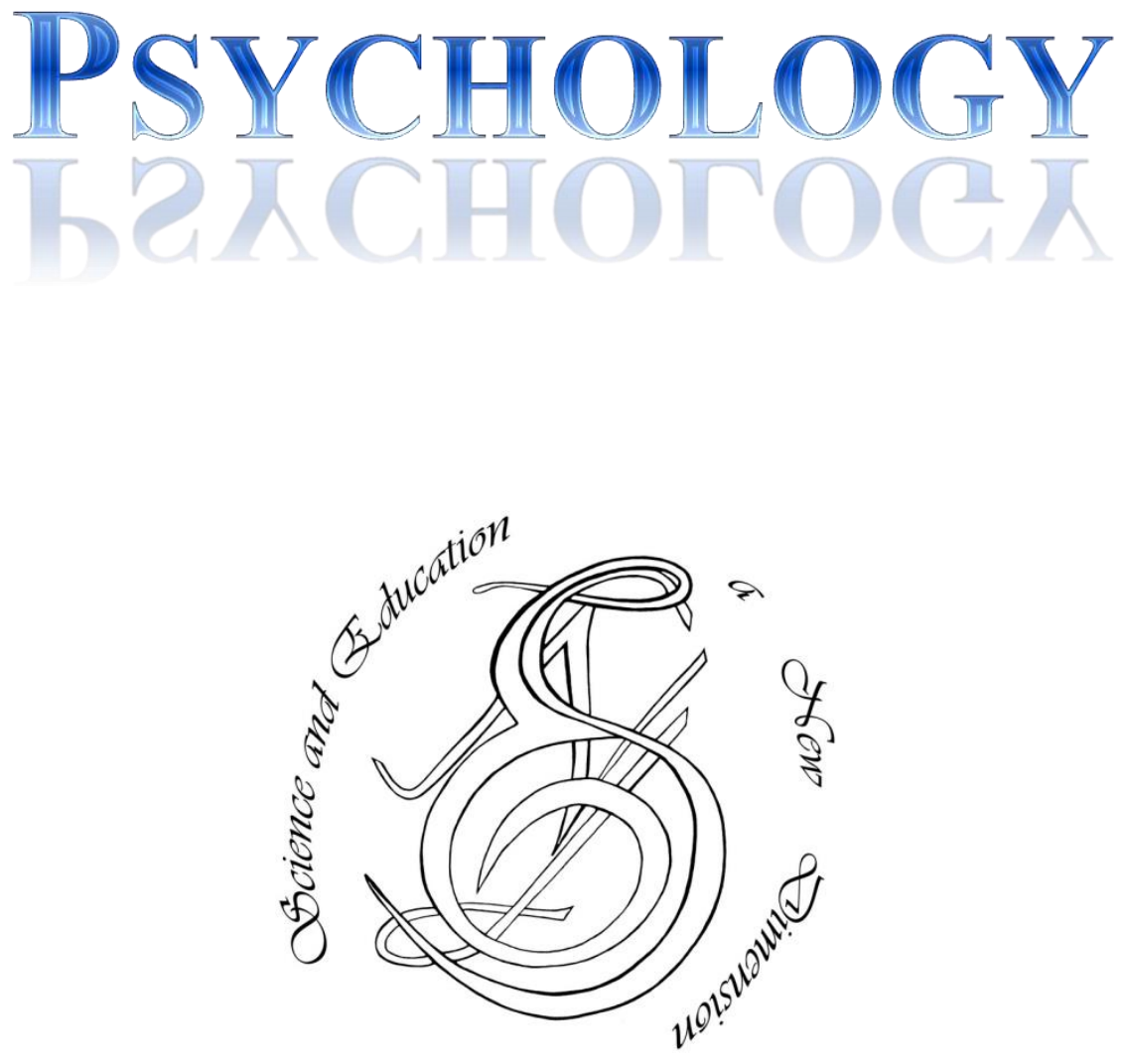
p-ISSN 2308-5258

V(70), Issue 170, 2018

SCIENCE AND EDUCATION A NEW DIMENSION

HTTPS:/DOI.ORG/10.31174/SEND-PP2018-170VI70

\section{Pedagogy and Psychology}

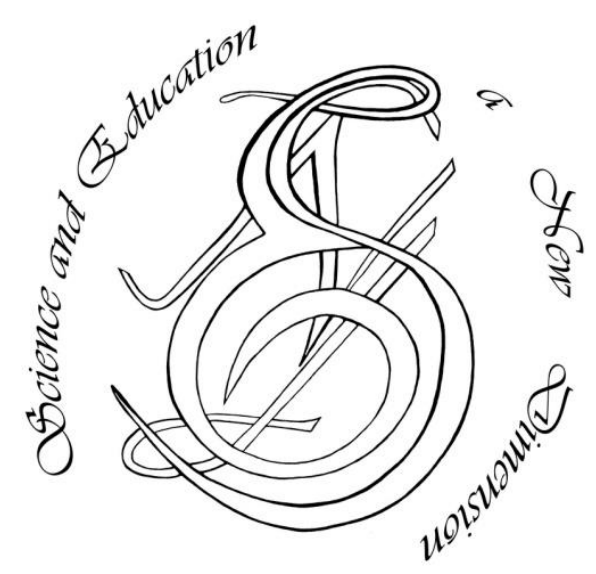




\section{Editorial board \\ Editor-in-chief: Dr. Xénia Vámos \\ Honorary Senior Editor: \\ Jenö Barkáts, Dr. habil. Nina Tarasenkova, Dr. habil.}

Andriy Myachykov, $\mathrm{PhD}$ in Psychology, Senior Lecturer, Department of Psychology, Faculty of Health and Life Sciences, Northumbria University, Northumberland Building, Newcastle upon Tyne, United Kingdom

Edvard Ayvazyan, Doctor of Science in Pedagogy, National Institute of Education, Yerevan, Armenia

Ferenc Ihász, PhD in Sport Science, Apáczai Csere János Faculty of the Universityof West Hungary

Ireneusz Pyrzyk, Doctor of Science in Pedagogy, Dean of Faculty of Pedagogical Sciences, University of Humanities and Economics in Włocławek, Poland

Irina Malova, Doctor of Science in Pedagogy, Head of Department of methodology of teaching mathematics andinformation technology, Bryansk State University named after Academician IG Petrovskii, Russia

Irina S. Shevchenko, Doctor of Science in Philology, Department of ESP and Translation, V.N. Karazin Kharkiv National University, Ukraine partment of Psychology, Faculty of Health and Life Sciences, Northumbria University, Northumberland Building, Newcastle upon Tyne, United Kingdom

Kosta Garow, $\mathrm{PhD}$ in Pedagogy, associated professor, Plovdiv University „Paisii Hilendarski”, Bulgaria

László Kótis, PhD in Physics, Research Centre for Natural Sciences, Hungary, Budapest

Larysa Klymanska, Doctor of Political Sciences, associated professor, Head of the Department of Sociology and Social Work, Lviv Polytechnic National University, Ukraine

Liudmyla Sokurianska, Doctor of Science in Sociology, Prof. habil., Head of Department of Sociology, V.N. Karazin Kharkiv National University

Marian Wloshinski, Doctor of Science in Pedagogy, Faculty of Pedagogical Sciences, University of Humanities and Economics in Włocławek, Poland

Melinda Nagy, PhD in Biology, associated professor, Department of Biology, J. Selye University in Komarno, Slovakia

Alexander Perekhrest, Doctor of Science in History, Prof. habil., Bohdan Khmelnitsky National University of Cherkasy, Ukraine

Nikolai N. Boldyrev, Doctor of Science in Philology, Professor and ViceRector in Science, G.R. Derzhavin State University in Tambov, Russia

Oleksii Marchenko, Doctor of Science in Philosophy, Head of the Department of Philosophy and Religious Studies, Bohdan Khmelnitsky National University of Cherkasy, Ukraine

Olga Sannikova, Doctor of Science in Psychology, professor, Head of the department of general and differential psychology, South Ukrainian National Pedagogical University named after K.D. Ushynsky, Odesa, Ukraine

Managing editor:

Barkáts N.
Oleg Melnikov, Doctor of Science in Pedagogy, Belarusian State University, Belarus

Perekhrest Alexander, Doctor of Science in History, Prof. habil., Bohdan Khmelnitsky National University in Cherkasy, Ukraine

Riskeldy Turgunbayev, CSc in Physics and Mathematics, associated professor, head of the Department of Mathematical Analysis, Dean of the Faculty of Physics and Mathematics of the Tashkent State edagogical University, Uzbekistan

Roza Uteeva, Doctor of Science in Pedagogy, Head of the Department of Algebra and Geometry, Togliatti StateUniversity, Russia

Seda K. Gasparyan, Doctor of Science in Philology, Department of English Philology, Professor and Chair, Yerevan State University, Armenia

Sokuriaynska Liudmyla, Doctor of sociological science. Prof. Head of Department of Sociology. V.N. Karazin Kharkiv National University, Ukraine

Svitlana A. Zhabotynska, Doctor of Science in Philology, Department of English Philolgy of Bohdan Khmelnitsky National, University of Cherkasy, Ukraine

Tatyana Prokhorova, Doctor of Science in Pedagogy, Professor of Psychology, Department chair of pedagogics andsubject technologies, Astrakhan state university, Russia

Tetiana Hranchak, Doctor of Science Social Communication, Head of department of political analysis of the Vernadsky National Library of Ukraine

Valentina Orlova, Doctor of Science in Economics, Ivano-Frankivsk National Technical University of Oil and Gas, Ukraine

Vasil Milloushev, Doctor of Science in Pedagogy, professor of Departament of Mathematics and Informatics, Plovdiv University „Paisii Hilendarski", Plovdiv, Bulgaria

Veselin Kostov Vasilev, Doctor of Psychology, Professor and Head of the department of Psychology Plovdiv University „Paisii Hilendarski”, Bulgaria

Vladimir I. Karasik, Doctor of Science in Philology, Department of English Philology, Professor and Chair, Volgograd State Pedagogical University, Russia

Volodimir Lizogub, Doctor of Science in Biology, Head of the department of anatomy and physiology of humans andanimals, Bohdan Khmelnitsky National University of Cherkasy, Ukraine

Zinaida A. Kharitonchik, Doctor of Science in Philology, Department of General Linguistics, Minsk State LinguisticUniversity, Belarus

Zoltán Poór, CSc in Language Pedagogy, Head of Institute of Pedagogy, Apáczai Csere János Faculty of the Universityof West Hungary 


\section{Statement:}

By submitting a manuscript to this journal, each author explicitly confirms that the manuscript meets the highest ethical standards for authors and co-authors. Each author acknowledges that fabrication of data is an egregious departure from the expected norms of scientific conduct, as is the selective reporting of data with the intent to mislead or deceive, as well as the theft of data or research results from others. By acknowledging these facts, each author takes personal responsibility for the accuracy, credibility and authenticity of research results described in their manuscripts. All the articles are published in author's edition.

THE JOURNAL IS LISTED AND INDEXED IN:

INDEX COPERNICUS: ICV 2014: 70.95; ICV 2015: 80.87; ICV 2016: 73.35

GOOGLE SCHOLAR

CROSSREF (DOI prefix:10.31174)

ULRICHS WEB GLOBAL SERIALS DIRECTORY

UNION OF INTERNATIONAL ASSOCIATIONS YEARBOOK

SCRIBD

ACADEMIA.EDU 


\section{CONTENT}

PEDAGOGY.

Training of future workers of the social sphere for implementation of social and pedagogical support of the minors exonerated with probation: result of experimental introduction of pedagogical conditions V. V. Angolenko.

Характеристика рівнів готовності майбутніх вихователів до формування доброзичливості у дітей старшого дошкільного віку

О. М. Доманюк.

Розвиток полікультурної компетентності студентів-іноземців у процесі навчання української мови

I. А. Дирда

Essential characteristics of national values in philosophical and psychological and pedagogical literature O. Z. Glushko.

Розвиток загальноєвропейського багатомовного комунікативного суспільства як соціокультурний чинник модернізації професійної підготовки фахівців з романо-германської філології

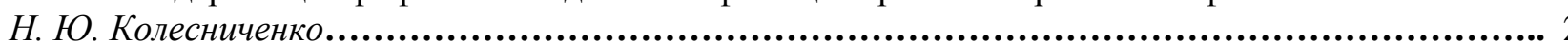

Забезпечення якості вищої освіти в Україні: виклики сьогодення

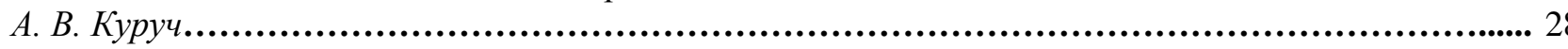

Критичне осмислення визначення компетентності в правових актах України про освіту

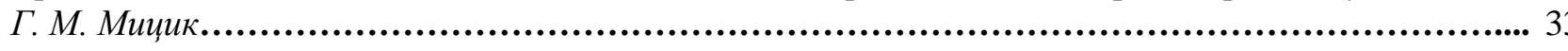

Redefining the system of higher education in Ukraine within the context of the internationalization process: practical rationale

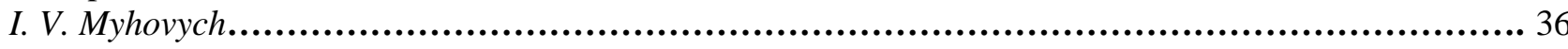

Критеріально-рівневе оцінювання розвитку музично-творчих здібностей дітей 6-7 років у позашкільних навчальних закладах

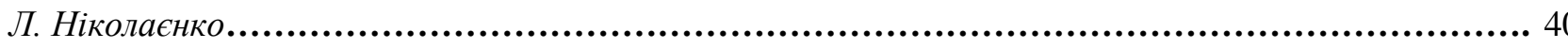

Готовність до інноваційної педагогічної діяльності як запорука формування у майбутніх вихователів закладів дошкільної освіти культури самовираження

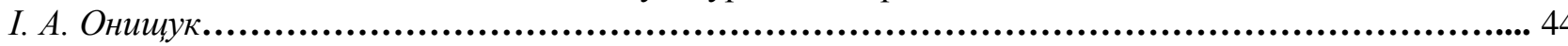

Деякі аспекти вивчення особистісного фактору екології людини

І. Л. Плаксієнко, П. В. Писаренко, М. С. Самойлік, Л. А. Колєснікова.

Advantages of using CLIL methodology in the process of future English language teachers' study in contemporary higher educational establishments of Ukraine

I. V. Shevchenko, O. M. Kordyuk.

The analysis of institutional organization of science of education management as a factor of development of education research methodology

T. V. Sych.

Особенности обучения географии старшеклассников на профильном уровне в современной украинской школе

И. В. Удовиченко.

Methodological complexity in the study of consciousness

K. Zobenko.

Формування екологічної культури майбутніх учителів природничих спеціальностей

В. В. Гончарук. 
PSYCHOLOGY

Дослідження психологічних детермінант альтруїзму волонтерів-медиків К. О. Талалаєв, Н. В. Кривиова, І. В. Бринза........................................................... 70 


\title{
PEDAGOGY
}

\section{Training of future workers of the social sphere for implementation of social and pedagogical support of the minors exonerated with probation: result of experimental introduction of pedagogical conditions}

\author{
V. V. Angolenko \\ Graduate student of the State higher educational institution "Donbass State Pedagogical University" (Sloviansk) \\ Paper received 06.06.18; Accepted for publication 14.06.18.
}

\author{
https://doi.org/10.31174/SEND-PP2018-170VI70-01
}

\begin{abstract}
In article questions of training of future workers of the social sphere for implementation of social and pedagogical support of the minors exonerated with probation have been considered: result of experimental introduction of pedagogical conditions; results of experimental introduction of pedagogical conditions of training of future workers of the social sphere for implementation of social and pedagogical support of the minors exonerated with probation have been proved.
\end{abstract}

Keywords: training of workers of the social sphere, minor offenders, penal system, probation service, pedagogical conditions.

Problem statement. Today in the conditions of intensification of the social conflicts in Ukraine social work is understood first of all as the practice-oriented branch of knowledge aimed at rendering the social help and support of people which belong to group of "social risk". At the same time, inevitably there is the whole complex of the problems connected with need of changes in training of future workers of the social sphere connected, in particular, with reforming of penal system and changes in standard and regulatory framework of the state.

Analysis of the last researches and publications. The Ukrainian scientists I. Bogatyrev, M. Evtukh, E. Karaman, V. Krivusha, T. Kushnareva, V. Sinev, D. Yagunov, I. Yakovets and others in their works have mentioned psychology and pedagogical aspects of work with various categories of offenders including juvenile that are convicted to the punishments which aren't connected with imprisonment, they have paid certain attention to training of future workers of the social sphere; I. Zvereva, A. Kapskaya, L. Mishchik, S. Harchenko have proved professional appointment of the modern social worker; V. Danilchenko, L. Kovchin, N. Lavrichenko, L. Sushchenko, L. Horuzhaya, I. Tsybulina have defined an originality of various directions of social and pedagogical activity of the expert of the social sphere in particular, human rights; T. Alekseenko, I. Bogdanova, S. Boltivets, Yu. Lysenko, O. Rasskazova, I. Trubavina, Yu. Chernetskaya and others have disclosed specifics of activity of the social teacher in various institutions. At the same time, the analysis of scientific works has shown that the questions connected with training of future workers of the social sphere for implementation of social and pedagogical support of the minors exonerated with probation are remained inadequately treated.

Therefore the purpose of the article is the justification of results of experimental introduction of pedagogical conditions of training of future workers of the social sphere for implementation of social and pedagogical support of the minors exonerated with probation.

Statement of basic materials. Training of future workers of the social sphere for professional activity, in particular to implementation of social and pedagogical support of the minors exonerated with probation demands from the expert of social work: knowledge of a technique of interaction and ability to make a psychological contact with minor offenders and their families taking into account gender features of the clients; to be guided by legal and regulatory base of respect for the rights of minors with illegal behavior; to rely on modern approaches of social work in the organization of implementation of social and pedagogical support of the minors exonerated with probation and so forth.

This all show a clear need for revision of the existing training programs in the direction 231 Social work and disciplines which teaching is directed to formation of knowledge and abilities of future worker of the social sphere for implementation of social and pedagogical support of the minors exonerated with probation. Therefore we have carried out the theoratical and methodological analysis of studying of experience of training of future workers of the social sphere for implementation of the professional functions, in particular for implementation of social and pedagogical support of the minors exonerated with probation and the analysis of educational programs of training of bachelors of social work in the municipal institution "Kharkiv Humanitarian and Pedagogical Academy" of the Kharkiv regional council, the Luhansk national university of Taras Shevchenko (Starobelsk), Umansky state pedagogical university of Pavel Tychina and Sumy state pedagogical university of A.S. Makarenko.

The analysis which has been carried out by us revealed that programs of subject matters provide superficial and almost deprived by a contextual component acquaintance with information allowing to create the necessary level of knowledge of future workers of the social sphere within a cycle of professionally focused disciplines. We have seen the solution of this problem in development and introduction in educational process of pedagogical conditions of training of workers of the social sphere for implementation of social and pedagogical support of the minors exonerated with probation, namely: integration of subject matters, for the direction of their educational potential on formation and development of complete system of knowledge and skills necessary for future worker of the social sphere at implementation of social and pedagogical 
support of the minors exonerated with probation; activization of practical training of future workers of the social sphere on the basis of social partnership with the Center of gender culture, Northeast interregional directorate concerning execution of criminal penalties and a probation of the Ministry of Justice; use in educational process of future workers of the social sphere for implementation of social and pedagogical support of the minors exonerated with probation of contextual technologies of training (risk assessment of commission of repeated offense, directing of a case, case methods, etc.).

Notice that, whereas the process of training of future workers of the social sphere for implementation of social and pedagogical support of the minors exonerated with probation happens in national educational standard and it is complete and system that has made impossible the local introduction of each of the pedagogical conditions proved by us, their realization during the experiment has happened in a complex and gradually.

At the first organizational stage it has been carried out training of all agents of pedagogical process for realization of pedagogical conditions, development and enrichment of substantial and methodical providing, forecasting of achievements. At this stage the result of realization of the specified conditions has been the filling of contents of the integrated working programs with subjects for formation and development of complete system of knowledge, skills necessary for future worker of the social sphere in the course of resocialization of minor offenders and introduction of elective courses "Bases of social work in a probation service" and "Social work in the conditions of penal system".

In particular, in contents of the training program "Introduction to specialty" has been itemized the subject "Minor Offenders as Objects of Social Work" which provides consideration of the following questions: regulatory framework of social work with minor offenders; interrelation of social work and penitentiary pedagogics, prevention of illegal behavior of minors taking into account gender features.

Contents of the training program "General, age and pedagogical psychology" has been complemented with the subject "Psychological Features of Minors with Deviant Behaviour" that has to take up the following questions: analysis of the reasons of deviant behavior of minors; deviant behavior, norm and pathology, sexual deviations of teenagers.

So, in contents of the training program of "The concept of social education in the history of a pedagogical thought" has been complemented with the subject "Social Education of Children with Illegal Behaviour" that has opened a question: adverse conditions of socialization of children as social and pedagogical problem; methods of social work with minor offenders.

In contents of the training program of "A basis of social and pedagogical diagnostics" has been itemized the subject "Social and Pedagogical Diagnostics in Probation Service for Convicts with Different Types of Punishment" that has opened a question: means of establishment of the level of development of social knowledge and skills of minor offenders.

The training program "Psychology and pedagogical bases of interpersonal communication" has been added to the subject "Social and Pedagogical Means of Formation of Communicative Interaction with Minor Offenders" that has opened a question: forms, methods and technics of communicative interaction of the expert of social work with minor offenders.

The training program of "A basis of a social and pedagogical training" is complemented with the subject "Use of Innovative Methods in the course of Resocialization of the Exonerated Minors" that has opened questions, namely: application a forum theater, a case management, a flash mob in the course of social and pedagogical support and resocialization of minor offenders.

Content of a subject matter "Bases of social and legal protection of the childhood. A technique of legal education and prevention of offenses" has been added to such Subject "Legal and Regulatory Framework of the Rights of the Child Who Is in the Conflict with the Law" and such questions have been opened: legal and regulatory framework of social work with children with illegal behavior; participation of law enforcement agencies, educational and fostering institutions, human rights and public organizations in resocialization of minor offenders; the latest forms and methods of preventive maintenance with the children who are in the conflict with the law.

Correction of content of a subject matter "Models and technologies of social work in the countries of the world" has been carried out due to expansion of questions of the subject "International Experience of Social Work with Minor Offenders", namely: mediative practices in work with minor offenders; recovery practices in work with the exonerated minors; programs of a probation concerning minors.

The content of a subject matter "A technique of gender education" has been complemented with the subject "Gender Sensitive Approach in Work with Minor Offenders", by means of questions: essence of a concept gendersensitive approach; use of resocialization technics taking into account gender-sensitive approach.

Introduction of elective courses "Bases of social work in probation service" and "Social work in the conditions of penal system" was intended to develop in students interest to social works in probation service; to acquaint with essence of the common theoretical problems and content of social work in probation service; to create conceptualization about the international and domestic experience of formation and development of social work in penal system; to study modern approaches to justification of activities of workers of the social sphere in penal system, in particular with application gender-sensitive approach; to acquaint students with methods and technologies of social work in the course of restorative justice and mediation, a probation and alternative forms of punishment. Each of subjects of elective courses have reflected certain tasks in formation of knowledge of future workers of the social sphere, in particular for implementation of social and pedagogical support of the minors exonerated with probation.

It should be noted that carrying out of lectures of elective courses "Bases of social work in probation service" and "Social work in the conditions of penal system" has happened with application of contextual methods and technologies of training that has contributed to the development of creative thinking in students, to formation of 
abilities to define own position and to use the acquired psychological and pedagogical and social and pedagogical knowledge in various educational and professional conditions.

Considerable potential in formation of the positive relation to interaction with minor offenders has involvement of students to volunteer activity. Therefore a special complex out-of-class form of work was "The gender open university: training of workers of social and legal spheres - "School of volunteering" [1], realized together with social partners: Center of gender culture, Northeast interregional directorate concerning execution of criminal penalties and a probation of the Ministry of Justice and teachers of department of social work and social pedagogics of municipal institution "Kharkiv Humanitarian and Pedagogical Academy" of the Kharkiv regional council.

The purpose of the project was to prepare and increase the level of gender competence, culture and ensuring gender education in future volunteers of a probation. We will notice that during the lectures "The gender open university: training of workers of social and legal spheres - "School of volunteering" the integration of pedagogical knowledge of the specified problematics has happened; moderators have applied contextual methods and forms of education that has allowed future workers of the social sphere to take active part during training and to approach real professional actions and the most important that they have seen possibilities of social partnership in effect.

With students of control and experimental group researches for the purpose of establishment of level of training of future workers of the social sphere for implementation of social and pedagogical support of the minors exonerated with probation have been conducted by three criteria:

- the cognitive component characterizes the theoretical knowledge gained in the course of mastering a profession from fundamental concepts in modern theories and concepts of social work. The cognitive component assumes students' acquirement of knowledge on the phenomena of deviant behavior, social disadaptation and also knowledge of the reasons, signs, characteristics, offenses; knowledge of norms and deviations in physical, mental, social, intellectual development of the minor offender and so forth.

Besides, the cognitive component of professional competence of the expert contains knowledge of conditions, directions, methods of the social and pedagogical help to the minor offenders exonerated with probation; knowledge and abilities to analyze relationship of the teenager and the environment, to define the nature of influence of this environment; knowledge of acts in the field of social protection of the minors exonerated with probation and understanding of need of constant control of the legislation which changes; mastering by students studying in direction "Social Work" of the system of the scientific and practical and special knowledge necessary for business communication without a conflict with workers and clients of social work; understanding of a role of professional training in practical activities, on the one hand, for achievement of the high level of professionalism, and on the other hand - for the solution of specific social problems of clients with which future worker of the social sphere works [2];

- the motivational component acts in the form of set of subjective indicators of activity. These include requirements, motives, interests, directives, valuable orientations, orientation of the personality, ideals, etc. The motivational and valuable component includes presence in future worker of the social sphere of steady interest in obtaining additional knowledge, abilities and practical experience of social and pedagogical support of the minor offenders exonerated with probation. This component provides formation by student of directives for interaction with the minor offenders exonerated with probation and their parents; stability of valuable orientations of the personality, orientation in professional activity to professional ethical requirements and so forth. Nevertheless, professional training needs to be directed in such a way as to convert natural needs for achievement of success into professional motivation for solution of social problems of minors. The components stated above are an important component of estimate of professional competence of future workers of the social sphere.

- the pragmatist and practical component is characterized by formation by future experts of the social and pedagogical abilities necessary for work with minor offenders. Future worker of the social sphere must be able to develop and to effectively apply the social technologies considering features of a modern combination of gender equality and specifics of sociocultural development of the minor for ensuring his social health.

Notice that in control group students have studied on the basis of traditional technologies of training, and in experimental group the described pedagogical conditions mentioned above have been introduced. After carrying out an experiment it has been realized control pedagogical diagnostics with use of the same methods of a research again, and during the ascertaining experiment. Efficiency of application of reasonable pedagogical conditions of training of future workers of the social sphere for implementation of social and pedagogical support of the minors exonerated with probation has been checked by means of similar indicators and criteria (tab. 1)

Table 1 Results of the comparative analysis

\begin{tabular}{|c|c|c|c|c|c|c|}
\hline \multirow{2}{*}{ Levels } & \multicolumn{7}{|c|}{ Criteria } \\
\cline { 2 - 7 } & motivational & \multicolumn{2}{c|}{ cognitive } & pragmatist and practical \\
\cline { 2 - 7 } & Before & After & Before & After & Before & After \\
\hline \multicolumn{7}{|c|}{ Control Group } \\
\hline critical & 54.3 & 42.2 & 37.7 & 29.5 & 43.9 & 33.4 \\
\hline reproductive & 38.7 & 43.9 & 42.6 & 46.1 & 48.3 & 52.7 \\
\hline productive & 7 & 13,9 & 19.7 & 24.4 & 7.8 & 13.9 \\
\hline \multicolumn{7}{|c|}{ Experimental Group } \\
\hline critical & 46 & 24 & 40 & 24 & 44 & 22 \\
\hline reproductive & 45 & 54 & 41 & 46 & 42 & 55 \\
\hline productive & 9 & 22 & 19 & 30 & 14 & 23 \\
\hline
\end{tabular}


Note that average data of levels of training of future workers of the social sphere for implementation of social and pedagogical support of the minors exonerated with probation in experimental group an increase in productive level has been increased by $11 \%$; reproductive level of training of future workers of the social sphere - by $8.7 \%$, critical level has been reduced by $20 \%$.

Analyzing results of control group we will notice that the productive level of training of future workers of the social sphere for implementation of social and pedagogical support of the minors exonerated with probation has been increased by $5.9 \%$, reproductive level of training by $4.4 \%$ while an indicator of critical level of training of future workers of the social sphere has been lowered by $10.3 \%$.

Conclusions and prospects of further scientific research in this direction. Ways of realization of the specified pedagogical conditions are shown in article and the efficiency of their introduction in teaching and educational process has been confirmed that has allowed to provide training of future workers of the social sphere for implementation of social and pedagogical support of the minors exonerated with probation and statistically significantly to increase its level in experimental group in comparison with control group. Techniques of training of future workers of the social sphere for work with minor offenders are the direction of further researches.

\section{REFERENCES}

1. Angolenko V.V., Beloliptseva E.V., Groshova E.V., Dyomina Yu.V., Isaeva T.A., Lysenko Yu.O., Rasskazova O.I., Preobrazhenskiy V.M., Tkachenko M.E., Chernetskaya Yu.I., Tsybulina I.V. Gender-sensitive approach in work with vulnerable segments of the population in the social and legal sphere: educational and methodical grant. / Made by Angolenko V.V., Beloliptseva E.V., Groshova O.V., Dyomina Yu.V., Isaeva T.A., Lysenko Yu.O., Rasskazova O.I.,
Preobrazhenskaya V.M., Tkachenko M.E., Chernetskaya Yu.I., Tsybulina I.V.; under the general edition of T.V. Otroshko. - K.: KSPA, 2017. -78 p.

2. Zimnyaya I.A. Competency-based approach: what its place in the system of approaches to education problems / I.A. Zimnyaya//the Higher education today. - 2006. - No. 8. - P. 20 26.

Подготовка будущих работников социальной сферы к осуществлению социально-педагогического сопровождения несовершеннолетних, освобожденных от отбывания наказания с испытанием: результат экспериментального внедрения педагогических условий

\section{В. В. Анголенко}

Аннотация. В статье рассмотрены вопросы подготовки будущих работников социальной сферы к осуществлению социально-педагогического сопровождения несовершеннолетних, освобожденных от отбывания наказания с испытанием: результат экспериментального внедрения педагогических условий; обосновании результаты экспериментального внедрения педагогических условий подготовки будущих работников социальной сферы к осуществлению социально-педагогического сопровождения несовершеннолетних, освобожденных от отбывания наказания с испытанием.

Ключевые слова: подготовка работников социальной сферы, несовершеннолетние правонарушители, пенитенциарная система, служба пробации, педагогические условия. 


\title{
Характеристика рівнів готовності майбутніх вихователів до формування доброзичливості у дітей старшого дошкільного віку
}

\author{
О. М. Доманюк \\ Кременецька обласна гуманітарно-педагогічна академія ім. Тараса Шевченка, м.Кременець, Україна \\ Corresponding author. E-mail: domanukoksana@gmail.com
}

Paper received 04.06.18; Accepted for publication 12.06.18.

\section{https://doi.org/10.31174/SEND-PP2018-170VI70-02}

\begin{abstract}
Анотація. У статті обгрунтовується актуальність проблеми готовності майбутніх вихователів закладів дошкільної освіти до формування доброзичливості у дітей старшого дошкільного віку. Представлені результати констатувального етапу дослідження рівнів готовності майбутніх вихователів до формування доброзичливості у дітей 5-7 років. Схарактеризовано рівні готовності за кожним із ії компонентів - когнітивним, особистісно-мотиваційним та діяльнісним, а також наводяться загальні показники.
\end{abstract}

Ключові слова: готовність майбутніх вихователів, рівні готовності, формування доброзичливості, діти старшого дошкільного віку.

На сучасному етапі розвитку суспільства перед освітніми закладами ставиться вимога виховувати соціально активну особистість із гуманістичними орієнтирами. Гуманізація освітнього процесу передбачає рівноправну, доброзичливу взаємодію всіх учасників процесу, побудову взаємин між педагогом і дітьми на основі доброти, довіри, поваги, толерантності. Адже лише гуманний вихователь спроможний виховати гуманну особистість (Л. Артемова, Г. Бєлєнька, Н. Гавриш, Л. Лохвицька, Т. Поніманська та інші). Таким чином, виникає необхідність удосконалення підготовки майбутніх вихователів закладів дошкільної освіти до створення сприятливих умов для формування особистісної зрілості дитини, іiі базових якостей, з-поміж яких виокремлюють доброзичливість [2; 3; 4].

Підготовку студентів до педагогічної діяльності фахівці пов'язують із іiї кінцевим результатом - формуванням готовності до певного виду педагогічної діяльності. Наукові праці у галузі теорії педагогічної освіти (І. Бех, Н. Кузьміна, В. Сластьонін, С. Шиянов та ін.) дозволяють диференціювати поняття «підготовка» як процес, а «готовність» - як результат цього процесу [1].

У дослідженні підготовки студентів до гуманістичного виховання дітей старшого дошкільного віку Т. Поніманська розглядає професійну підготовку як педагогічний процес, спрямований на розвиток готовності студента до майбутньої професійної діяльності; готовність до професійної діяльності - як мету і результат підготовки, що дозволяє здійснювати професійну діяльність ефективно [4].

3 метою виявлення рівнів готовності майбутніх вихователів до формування доброзичливості у дітей старшого дошкільного віку ми провели дослідження, в якому взяли участь 180 студентів 1-5 курсів денної та заочної форми навчання Кременецької обласної гуманітарно-педагогічної академії ім. Тараса Шевченка та Кременецького педагогічного коледжу.

Для констатувального зрізу ми використали комплекс діагностичних методик, до якого ввійшли:

- авторське діагностичне опитування «Розуміння сутності категорії «доброзичливість»»;

- орієнтаційна анкета Б. Басса [5];

- тест-опитувальник А. Мехрабіана для вимірювання мотивації досягнення [5];

- діагностика типових способів поведінки в конфлі- ктних ситуаціях (на основі тесту Томаса);

- адаптований тест «Самооцінка професійнопедагогічної мотивації» (А. Циплюк);

- методика «Ціннісні орієнтації особистості» В. Шапар [5] та ін.

Встановлено, що за когнітивним компонентом готовності майбутніх вихователів до формування доброзичливості у дітей 5-7 років, критерієм якого ми визначили знання про зміст доброзичливості у дітей старшого дошкільного віку, елементарний рівень констатовано у 8, 9\% (16 осіб). Студенти цього рівня не володіють понятійно-термінологічним змістом категорії «доброзичливість»; не завжди ідентифікують і диференціюють доброзичливість, не можуть назвати основних ознак та способів іiі прояву у дітей старшого дошкільного віку; у них не сформовані уявлення про доброзичливість як інтегративну якість особистості; відсутні теоретико-методологічні знання 3 дошкільної педагогіки, дитячої психології та методик дошкільної освіти.

Несталий рівень констатовано у $25 \%$ (45 осіб). У студентів цього рівня - поверхневі знання про понятійно-термінологічний зміст категорії «доброзичливість»; не сформовані уявлення про доброзичливість як інтегративну якість особистості; вони допускають неточності у ідентифікації і диференціації доброзичливості, на власний розсуд називають способи іiі прояву, зазначають декілька основних ознак доброзичливості у дітей 5-7 років; поверхневі теоретико-методологічні знання 3 дошкільної педагогіки, дитячої психології та методик дошкільної освіти.

Суперечливий рівень готовності до формування доброзичливості у дітей старшого дошкільного віку констатовано у 46, 7\% опитаних (84 особи). Їм притаманні відносно повні, чіткі знання про понятійнотермінологічний зміст категорії «доброзичливість»; студенти мають глибокі уявлення про доброзичливість як інтегративну якість особистості, але не обгрунтовують свою думку; вони вірно ідентифікують та диференціюють доброзичливість, способи ії прояву; знають та називають значну кількість основних ознак доброзичливості у старших дошкільників; у них достатні, відтворюючі теоретико-методологічні знання з педагогіки, психології та методик дошкільної освіти, вміння адаптувати їх під свої потреби.

Оптимальний рівень констатовано у 19, 4\% (35 осіб). Студенти, умовно віднесені до зазначеного рівня, 
розуміють і можуть чітко та правильно пояснити понятійно-термінологічний зміст категорії «доброзичливість»; вони вірно ідентифікують і диференціюють доброзичливість, способи іiі прояву, обгрунтовують свою думку; знають та називають багато основних ознак доброзичливості у дітей старшого дошкільного віку; мають глибокі та усвідомлені уявлення про доброзичливість як інтегративну якість особистості; володіють високим рівнем теоретико-методологічних знань 3 педагогіки, психології та методик дошкільної освіти, вміють адаптувати їх під свої потреби.

За особистісно-мотиваційним компонентом у $17,8 \%$ студентів (32 особи) встановлено елементарний рівень особистісної спрямованості на формування доброзичливості у дітей старшого дошкільного віку. При цьому в майбутніх вихователів низька професійнопедагогічна мотивація, відсутнє прагнення стати доброзичливим педагогом; вони не надають значущості формуванню доброзичливості у дітей 5-7 років; спостерігається негативне ставлення до дитини, як до суб'єкта доброзичливої взаємодії, відсутня зорієнтованість на емпатійно-особистісну взаємодією з вихованцями; відсутні ціннісні орієнтації та професійні здібності, які сприяють вихованню доброзичливості у старших дошкільників; студенти, віднесені до елементарного рівня, не вміють здійснювати самоспостереження й самоаналіз власної ролі у формуванні доброзичливості у старших дошкільників, у них не сформовані потреби у професійному вдосконаленні.

У $31,1 \%$ (56 осіб) досліджуваних констатовано несталий рівень готовності до формування доброзичливості у дітей старшого дошкільного віку: у них задовільний рівень професійно-педагогічної мотивації, ситуативне прагнення стати доброзичливим педагогом; зрідка проявляються потреби у професійному вдосконаленні; спостерігається байдуже ставлення до дитини, як до суб'єкта доброзичливої взаємодії, рідко проявляється зорієнтованість на емпатійно-особистісну взаємодією 3 ними; констатовано зародкове становлення ціннісних орієнтацій та професійних здібностей, що сприяють вихованню доброзичливості у старших дошкільників (емпатія, толерантність, уміння будувати педагогічне спілкування); вони надають незначної актуальності проблемі формування доброзичливості у дошкільників; студенти зазначеного рівня не можуть здійснювати самоспостереження й адекватний самоаналіз власної ролі у формуванні доброзичливості у старших дошкільників, хоча вважають педагога прикладом для наслідування.

У $36,7 \%$ студентів (66 осіб) переважає суперечливий рівень готовності до формування доброзичливості. У них достатня професійно-педагогічна мотивація, присутнє прагнення стати доброзичливим педагогом; спостерігається емоційно позитивне ставлення до дітей, зорієнтованість на емпатійно-особистісну взаємодію 3 ними; сформовані ситуативні потреби у професійному вдосконаленні; проявляються ціннісні орієнтації та професійні здібності, які сприяють вихованню доброзичливості у старших дошкільників (гуманність, емпатія, толерантність, шанобливість, уміння організувати педагогічне спілкування); вони надають значущості формуванню доброзичливості у дітей старшого дошкільного віку; самоспостереження й самоаналіз власної ролі у формуванні доброзичливості у старших дошкільників здійснюють не завжди, допускають неточності.

Оптимальний рівень готовності до формування доброзичливості у старших дошкільників за особистісно-мотиваційним компонентом виявлено у 14,4\% майбутніх вихователів (26 осіб). У цих студентів сформована професійно-педагогічна мотивація, яскраво виражене прагнення стати доброзичливим педагогом; у них розвинуті потреби у професійному вдосконаленні; завжди емоційно позитивне ставлення до дітей, зорієнтованість на емпатійно-особистісну взаємодією з ними; розвинуті стійкі ціннісні орієнтації та високий рівень професійних здібностей, які сприяють вихованню доброзичливості у дітей 5-7 років (гуманність, душевність, емпатія, толерантність, шанобливість, уміння організувати педагогічне спілкування); вони розуміють та обгрунтовують значущість формуванню доброзичливості у старших дошкільників; систематично і грунтовно проводять самоспостереження й самоаналіз власної ролі у формуванні доброзичливості у старших дошкільників.

За діяльнісним компонентом, критерієм якого ми визначили володіння методикою формування доброзичливості у дітей старшого дошкільного віку, елементарний рівень готовності майбутніх вихователів до формування доброзичливості у старших дошкільників констатовано у 12,2\% опитаних (22 особи). У цих студентів спостерігаються зародкові професійні уміння і навички доброзичливої взаємодії з дітьми, низька здатність до організації доброзичливих взаємин; відсутнє володіння методикою формування доброзичливості на засадах особистісно-орієнтованого підходу; вони не можуть грунтовно проектувати роботу 3 формування доброзичливості у дітей старшого дошкільного віку, застосовують 1-2 форми роботи; зрідка можуть знаходити оптимальні рішення педагогічного впливу на дитину, що стимулюють вияв доброзичливості.

У 43,3\% (78 осіб) констатовано несталий рівень готовності до формування доброзичливості у старших дошкільників. У них виявлено часткову сформованість професійних умінь і навичок доброзичливої взаємодії $з$ дітьми, ситуативну здатність до організації доброзичливих взаємин; недостатнє володіння методикою формування доброзичливості на засадах особистісноорієнтованого підходу; слабо сформовані вміння проектувати роботу з формування доброзичливості у дітей старшого дошкільного віку, вони застосовують 3-4 однотипні форми роботи; в деяких ситуаціях можуть знаходити оптимальні рішення педагогічного впливу на дитину, що стимулюють вияв доброзичливості.

Суперечливий рівень виявлено у $30 \%$ (54 особи) студентів: у них достатній рівень професійних умінь і навичок доброзичливої взаємодії з дітьми, здатності до організації доброзичливих взаємин; нечітке володіння методикою формування доброзичливості на засадах особистісно-орієнтованого підходу; майбутні педагоги вдало проектують роботу щодо формування доброзичливості у дітей старшого дошкільного віку, застосовують різні форми роботи; у більшості випадків уміють знаходити оптимальні рішення педагогічного впливу на дитину, що стимулюють вияв доброзичливості.

У $14,4 \%$ (26 осіб) констатовано оптимальний рівень готовності. У цих студентів сформовані професійні уміння і навички доброзичливої взаємодії з діть- 
ми, висока здатність до організації доброзичливих взаємин; високий рівень володіння методикою формування доброзичливості на засадах особистісноорієнтованого підходу; вони творчо та креативно проектують роботу щодо формування доброзичливості у дітей старшого дошкільного віку, застосовують різноманітні (новітні) форми роботи; завжди вміють знаходити оптимальні рішення педагогічного впливу на дитину, що стимулюють вияв доброзичливості.

Узагальнення отриманих результатів дозволяє говорити про те, що у 26\% майбутніх вихователів (26 осіб) констатовано елементарний рівень готовності до формування доброзичливості у дітей старшого дошкільного віку: у них, здебільшого, відсутні знання про зміст доброзичливості, не сформована особистісна спрямованість та володіння методикою іiї формування у дітей 5-7 років. У $30 \%$ опитаних (54 особи) виявлено несталий рівень готовності: студентам притаманні поверхневі знання про зміст доброзичливості, ситуативна спрямованість та часткове володіння методикою іiі формування. Суперечливий рівень готовності констатовано у $38,9 \%$ реципієнтів (70 осіб): це - студенти 3 відносно повними, чіткими знаннями про зміст добро- зичливості у дітей старшого дошкільного віку, зі сформованою особистісною спрямованістю та достатнім рівнем володіння методикою формування зазначеної якості. У 16,7\% (30 осіб) майбутніх вихователів констатовано оптимальний рівень готовності - їм притаманні глибокі та усвідомлені знання про зміст доброзичливості у дітей 5-7 років, чітка особистісна спрямованість та майстерне володіння методикою іï формування у старших дошкільників.

Таким чином, проведений констатувальний етап дослідження підтвердив значущість проблеми формування доброзичливості у дітей старшого дошкільного віку та дозволив схарактеризувати рівні готовності майбутніх вихователів до формування зазначеної якості у старших дошкільників (оптимальний, суперечливий, несталий, елементарний). Результати експерименту зумовлюють необхідність пошуку нових підходів у змісті та методах професійної підготовки майбутніх вихователів.

Перспективу подальшої роботи ми вбачаємо в розробці та експериментальній перевірці методики підготовки майбутніх вихователів до формування доброзичливості у дітей старшого дошкільного віку.

\section{ЛIТЕРАТУРА}

1. Бех І. Д. Виховання особистості. - К. : Либідь, 2008., 848 с.

2. Белєнька Г. В. Підготовка вихователя до розвитку особистості дитини в дошкільному віці : монографія. - К. : Видво НПУ імені М. П. Драгоманова, 2009., 310 с.

3. Гавриш Н. Доброму всюди добре, або як допомогти дітям зростати доброзичливими // Вихователь-методист дошкільного закладу, 2017. №8, С.40-45.

4. Поніманська Т. І. Підготовка педагога до виховання дітей старшого дошкільного віку в світлі гуманістичної парадигми // Науковий вісник Донбасу, 2013., № 4.

5. Фетискин Н. П., Козлов В. В., Мануйлов Г. М. Социальнопсихологическая диагностика развития личности и малых групп. - М., Изд-во Института Психотерапии, 2002., 490 с.

\section{REFERENCES}

1. Bekh I. D. Education of the person. - K. : Lybid, 2008.,848 s.

2. Bielienka H. V. Preparation of the educator for the development of the child's personality in preschool age: monograph. $-\mathrm{K}$. : Vyd-vo NPU imeni M. P. Drahomanova, 2009., 310 s.

3. Havrysh N. Good everywhere good, or how to help children grow benevolent // Vykhovatel-metodyst doshkilnoho zakladu, 2017., №8, S.40-45.

4. Ponimanska T. I. Preparation of a teacher for the upbringing of children of the senior preschool age in the light of a humanistic paradigm // Naukovyi visnyk Donbasu, 2013., № 4.

5. Fetyskyn N. P., Kozlov V. V., Manuilov H. M. Socialpsychological diagnostics of personality development and small groups. - M., Yzd-vo Ynstytuta Psykhoterapyy, 2002., $490 \mathrm{~s}$.

Characteristics of the future educators' readiness for the formation of benevolence in senior preschool-aged children

O. M. Domaniuk

Abstract. The article substantiates the problem urgency of future preschool establishments educators' readiness for the formation of benevolence in senior preschool-aged children. The results of the preliminary stage study of the future educators' readiness for the benevolence formation in children 5-7 years of age are presented. Levels of readiness are characterized according to each of its components as cognitive, personal-motivational and activity-oriented, and general indicators are given.

Keywords: readiness of future educators, levels of readiness, formation of benevolence, children of the senior preschool age.

Характеристика уровней готовности будущих воспитателей к формированию доброжелательности у детей старшего дошкольного возраста

О. М. Доманюк

Аннотация. В статье обосновывается актуальность проблемы готовности будущих воспитателей дошкольных учреждений к формированию доброжелательности у детей старшего дошкольного возраста. Представлены результаты констатирующего этапа исследования уровней готовности будущих воспитателей к формированию доброжелательности у детей 5-7 лет. Дана характеристика уровней готовности за каждым компонентом - когнитивным, личностно-мотивационным и деятельностным, а также приводятся общие показатели.

Ключевые слова: готовность будущих воспитателей, уровни готовности, формирования доброжелательности, дети старшего дошкольного возраста. 


\title{
Розвиток полікультурної компетентності студентів-іноземців у процесі навчання української мови
}

\author{
I. А. Дирда \\ Кафедра української мови, Криворізький державний педагогічний університет \\ Paper received 30.05.18; Accepted for publication 07.06.18.
}

\section{https://doi.org/10.31174/SEND-PP2018-170VI70-03} Анотація. У статті з’ясовано сутність поняття «полікультурна компетентність»; наголошено на особливостях навчання іно-
земних студентів в Україні; проаналізовано навчальні плани, програми і підручники з української мови для іноземців; за-
пропоновано методику розвитку полікультурної компетентності іноземних студентів у процесі вивчення української мови;
презентовано авторський посібник «Полікультурна освіта студентів-іноземців» та визначено його роль у розвитку полікуль-
турної компетентності іноземних студентів.

Ключові слова: полікультурна компетентність, навчання іноземних студентів, мовна підготовка, розвиток полікультурної компетентності.

Вступ. Мова країни, у якій перебувають та навчаються іноземці, $\epsilon$ не тільки навчальним предметом, а й освітньою дисципліною, засобом усебічного розвитку упродовж життя та провідником майбутніх фахівців у їхному становленні як професійних особистостей. Для іноземців, що навчаються в українських закладах вищої освіти (ЗВО), українська мова є мовою соціокультурного оточення, викладається задля формування умінь міжкультурної комунікації. Підготовка іноземних фахівців в Україні - це одна 3 ефективних форм культурного і наукового співробітництва, що сприяє зміцненню авторитету України на міжнародній арені, є джерелом додаткового фінансування освіти.

Короткий огляд публікацій за темою. Суттевий внесок в аналіз проблеми вивчення української мови як іноземної зроблено такими науковцями, як Н. Бабич, 3. Бакум, Л. Барановська, О. Біляєв, І. Бім, С. Караман, О. Копусь, М. Пентилюк, Б. Сокіл, О. Тростинська, Н. Ушакова, С. Яворська. У процесі навчання української мови іноземні студенти набувають досвіду міжкультурної комунікації, результатом якого $є$ розвиток полікультурної компетентності. Зарубіжні та українські дослідники (Дж. Беннет, Н. Богатих, I. Васютенкова, Л. Воротняк, Л. Гончаренко, О. Джуринський, В. Кузьменко, Л. Перетяга, Т. Поштарьова, І. Соколова, Б. Татохов, О. Щеглова) зробили різні акценти щодо змісту поняття «полікультурна компетентність» залежно від цілей та сфери його застосування. Для створення авторської методики було проаналізовано чинні програми української мови для іноземних студентів: програма «Українська мова» (укладачі О. Черемська, Г. Гайдамака), «Українська мова як іноземна у кредитно-модульному навчанні» (укладачі В. Чумак, О. Чумак), «Українська мова (для іноземних студентів)» (укладач Н. Чабан), робоча навчальна програма 3 дисципліни «Українська мова» для студентів I курсу (іноземних громадян) усіх спеціальностей усіх напрямів підготовки (ДВНЗ «Криворізький національний університет») (укладач Н. Кравцова).

Мета. Реалізувати авторську методику розвитку полікультурної компетентності студентів-іноземців у навчальному посібнику.

Результати та їх обговорення. Останні роки спостерігається тенденція до збільшення кількість інозе- мних студентів, які бажають отримати вищу освіту в Україні. Більшість іноземних студентів мають низький рівень інформованості про політичну, економічну та соціальну системи нашої країни; про норми, звичаї, традиції та культуру народу; про систему вищої освіти. Для значної частини іноземців уперше постає проблема інтернаціоналізації, необхідності комунікації 3 носіями різних культур.

Узагальнюючи думки науковців (І. Зозуля, Л. Рибаченко, Б. Сокіл), варто виокремити чинники, що зумовлюють навчання іноземних студентів:

- політичний (навчання іноземних громадян сприяє зростанню і зміцненню міжнародного престижу України за кордоном, створенню атмосфери довіри і взаємопорозуміння);

- економічний (зростання ролі випускників українських 3ВО, особливо тих, хто працює в сфері бізнесу і може просувати українські товари та послуги на ринках своїх країн);

- психологічний (психологічне адаптування студентів-іноземців до незвичних умов життя, спілкування, нової культури, традицій).

Головним чинником створення методичного та інформаційного забезпечення мовної підготовки іноземних студентів українських закладах вищої освіти $є$ розроблення «Сдиної типової навчальної програми 3 української мови для іноземних студентів» ( Л. Дзюбенко, С. Філіпчук, Т. Шевчук, В. Дубинський, Л. Новицька, С. Чезганов), яка опирається на навчальний план МОН України (наказ № 260 від 04.04.2006 р.). Програма складається 3 трьох розділів. I розділ визначає мету, завдання, етапи, зміст, методи і форми навчання, форми контролю, орієнтовану тематику текстових матеріалів. У II розділі йдеться про основний етап навчання (I-II курси). Кількість годин для вивчення української мови складає 652 (490 аудиторні та 162 самостійні). У III розділі Програми подано опис завершального етапу навчання (III курс та перший семестр IV курсу). Серед базових положень програми формування у студентів-іноземців навичок та умінь для спілкування в суспільно-політичній та соціально-культурній сферах у руслі міжкультурної комунікації та розвиток загальнолюдських цінностей $є$ ключовими.

Відповідно до Єдиної типової навчальної програми та наказу МОН України № 260, на основі такої про- 
грами на мовних кафедр вищих навчальних закладах розроблено робочі навчальні програми з урахуванням специфіки профілю навчання та контингенту студентів. Означений нормативний документ втратив чинність від 18.08.2016 наказом МОН України № 997 «Про визнання таким, що втратив чинність, наказу Міністерства освіти і науки України від 04.04.2006 № 260 «Про вивчення української (російської) мови іноземними студентами і аспірантами», обсяг годин, необхідних студентам-іноземцям для навчання та/або побутового спілкування відповідно до освітніх програм встановлюється та забезпечується керівниками вищих навчальних закладів. Отже, відповідальність за регулювання навчальних програм та обсяг годин повністю покладається на навчальний заклад, унаслідок чого ми можемо спостерігати невідповідність годин у 3BO.

Іноземні студенти - це соціалізовані зрілі особистості, сформовані під впливом того середовища, у якому вони виховувалися. Зазвичай вони мають певну життєву позицію, цільові настанови та систему цінностей. Тому одним із завдань сучасної освіти в умовах світової глобалізації стає створення умов для того, щоб іноземні студенти набували досвіду міжкультурного спілкування, у процесі якого відбувається формування полікультурної компетентності.

Сутність полікультурної компетентності полягає в усвідомленні людиною культурного різноманіття світу, доброзичливе, відкрите й неупереджене ставлення до будь-якої культури та іiі носіїв. Полікультурна компетентність охоплює перспективу міжкультурних контактів, свідоме знання власної культури, певні системи поглядів на створення культурних контрастів, здатність аналізувати взаємодію, прогнозувати непорозуміння, уміти долати стереотипи [5].

Задля розвитку полікультурної компетентності ми розробили авторську методику, яку розміщено в посібнику «Полікультурна освіта студентів-іноземців».

Мета створеної методики: навчати розуміти особливості різних національностей та взаємодіяти з представниками інших культур; активізувати знання про власну культуру та навчати культурного самоаналізу; навчати студента толерантного ставлення до будьякої культури та іiі носіїв, показати причинонаслідкові зв'язки помилкових суджень і традицій, звичаїв тієї чи тієї країни; домогтися усвідомлення особливостей міжкультурного спілкування, прогнозувати непорозуміння.

Посібник складається 312 тематичних блоків: «Світова культура», «Виховання толерантності», «Глобальні проблеми людства», «Національна символіка», «Мій дім - моя фортеця», «Традиційна сім'я: традиції та сучасність», «Мистецтво та література», «Освіта та виховання», «Мовленнєвий етикет», «Соціальні інститути» тощо.

Вибір тем блоків зумовлено національністю студентів, напрямом їх навчання та рівнем знань української мови (В1 - В2). Задля розвитку полікультурної компетентності студентів ураховано історію кожного народу, особливості різних культур, традицій, звичаїв, поведінки, способу мислення їх представників.

В основу створеної методики покладено комунікативний підхід, який спрямований саме на практику спілкування. Упровадження комунікативного підходу передбачає максимальне заглиблення студента в українськомовний процес, що досягається завдяки зведенню послуговування рідною мовою до мінімуму. Так, на основному етапі навчання української мови студенти виокремлюють значення нових слів через його пояснення, визначення.

Робота над кожним тематичним блоком передбачає певні етапи.

На прикладі однієї з тем розглянемо процес розвитку полікультурної компетентності студентівіноземців. У посібнику студентам представлено тему «Глобальні проблеми людства».

На етапі прелімінарних вправ студентам запропоновано проглянути малюнки (рис. 1.) за темою та дати відповіді на такі запитання.

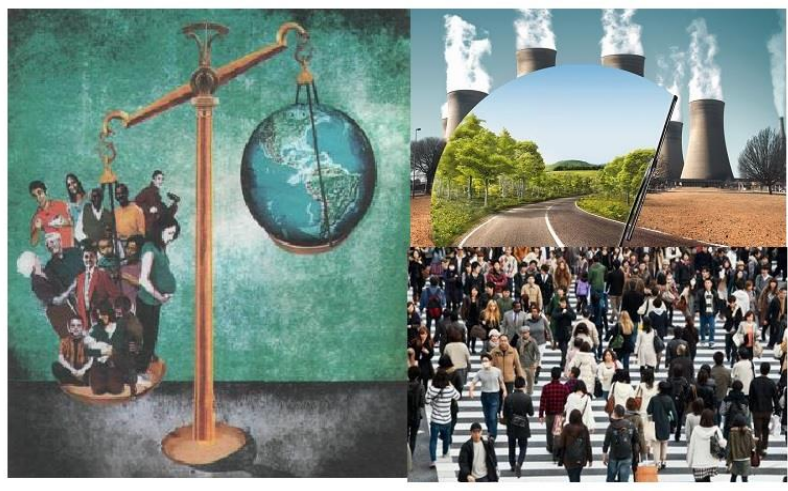

Рис.1. Глобальні проблеми людства.

1. Проаналізуйте малюнки. Які символи зображені на них? Доберіть відповідний прикметник, який характеризує природу тієї чи тієї проблеми?

2. Використовуючи подані словосполучення (сміття, бездомні тварини, насичений транспортний рух, вихлопні гази, використання поліетиленових пакетів), запропонуйте розв'язання таких проблем. Розкажіть про ваше особисте сприяння охороні навколишнього середовища.

3. Щоб ви хотіли змінити або удосконалити у тому місці, де ви живете? Використовуйте такі фрази:

Я хотів би бачити більше / менше ...

Як на мене, буде краше, якщо ...

На мою думку, не повинно бути ..., тому що ...

Керуючись принципами наочності (робота 3 ілюстрованим матеріалом, описати малюнок, пояснити зображення), наступності та перспективності (підготовка до читання, прогнозування змісту тексту, самостійна семантизація слова на основі встановлення смислових зв'язків, робота над новою лексикою за текстом за допомогою тлумачних словників, пояснень викладача), ми обирали прелімінарні вправи.

Основний етап передбачає ознайомлення з текстом. Задля розвитку полікультурної компетентності обрано принцип текстоцентризму, позаяк текст $є$ важливим інструментом у процесі оволодіння чотирма видами мовленнєвої діяльності.

Наступний етап передбачає роботу над текстом (виконання лексико-граматичних та мовленнєвокомунікативних вправ, робота над трансформацією тексту). На етапі виконання лексико-граматичних вправ реалізовано принцип систематичності та послідовності, наступності та перспективності для повто- 
рення пройденого матеріалу, принцип урахування рідної мови.

Подано приклади таких вправ за темою «Глобальні проблеми людства»:

1) утворіть від поданих іменників прикметники. Географія, клімат, суспільство, екологія, політика,пріоритет, сировина;

2) дайте визначення таким словосполученням: глобальна проблема, демографічний бум, зелена революція, екологічна рівновага, міждисииплінарний підхід;

3) розділіть слова на групи: демографічна, продовольча та екологічна проблема;

4) складіть речення 3 поданими словами: дефіųuт, енергетика, стихійні лиха, захворювання, виробництво, довкілля, грунт.

Після роботи над граматикою української мови та лексичними одиницями студенти працюють над змістом тексту. На наступному етапі запропоновано мовленнєво-комунікативні вправи.

Для прищеплення поваги до будь-якої культури, почуття толерантності, розуміння особливостей різних народностей, на етапі виконання мовленнєвокомунікативних вправ обрано полікультурний підхід, особистісно орієнтований підхід та принцип гуманізму та індивідуалізації. Наведемо приклад вправ за поданою темою.

1. Дайте відповіді на запитання. У чому полягає сутність глобалізації світового господарства? Які чинники зумовлюють процес глобалізації? Охарактеризуйте соціально-економічні передумови глобалізації. Назвіть основні ознаки глобальних проблем сучасності. У чому полягає зміст глобальних проблем у сфері взаємодії природи і суспільства? Назвіть характерні риси глобальних проблем у сфері суспільних відносин. Чим характеризуються глобальні проблеми у сфері розвитку людини та забезпечення піi майбутнього існування?

2. У зв'язку з чим у тексті використано такі числа: $2,5250202 / 31$

3. Чи можна виокремити найважливішу проблему серед запропонованих?

4. Яка актуальна глобальна проблеми вашої країни? Як населення та уряд сприяє розв'язанню проблеми?

5. Побудуйте діалог, пов'язаний з певною проблемою та використовуйте такі слова і словосполучення: дефіциит, енергетика, стихійні лиха, замкнутий цикл використання ресурсів, зелена револючія, виробницт- во, довкілля, грунт, глобальна проблема, демографічний бум.

6. Намалюйте плакат на тему «Глобальні проблеми людства», використовуючи символи і приготуйте виступ за темою.

Додатково кожен тематичний блок містить роботу над трансформацією тексту, яка сприяє більш глибокому його розумінню. Лише той текст осмислений, головний зміст якого можна презентувати у стисненій формі. Запропоновано такі завдання: скласти конспект тексту; скласти питальний та розгорнутий тезовий план до тексту; написати анотацію; скласти стислий переказ; переказати текст.

У кінці кожної теми студентам запропоновано робота 3 формування навичок аудіювання або самостійна робота 3 додатковим матеріалом для закріплення отриманих умінь та навичок (читання, самостійна трансформація тексту, робота над змістом тексту).

Висновки. Отже, задля розвитку полікультурної компетентності розроблено авторську методику, яку розміщено в посібнику «Полікультурна освіта студентів-іноземців». Посібник складається з 12 тематичних блоків. Вибір тем блоків був зумовлений національністю студентів, напрямом їх навчання та рівнем знань української мови (В1 - В2). Задля розвитку полікультурної компетентності студентів ураховано історію кожного народу, особливості різних культур.

Мета створеної методики: навчати розуміти особливості різних національностей та взаємодіяти з представниками інших культур; активізувати знання про власну культуру та навчати культурного самоаналізу; навчати студента толерантного ставлення до будьякої культури та ii носіїв, показати причинонаслідкові зв'язки помилкових суджень і традицій, звичаїв тієї чи тієї країни; домогтися усвідомлення особливостей міжкультурного спілкування, прогнозувати непорозуміння.

Робота над кожним тематичним блоком передбачає певні етапи: прелімінарні вправи, основний етап (ознайомлення з текстом), лексико-граматичні вправи, мовленнєві та комунікативні вправи, робота над трансформацією тексту.

Отже, реалізація викладачем створеної методики у практиці навчання іноземних студентів буде мати позитивні результати у процесі розвитку полікультурної компетентності студентів-іноземців.

\section{ЛІТЕРАТУРА}

1. Бакум 3. П. Українська мова для студентів-іноземців (рівень C1) : [навчальний посібник] / Бакум 3. П., Городецька В. А., Суховенко Н. І. - Кривий Ріг, 2013. - Ч. ІІ. - 98 c.

2. Бакум 3. П., Костюк С. С. Методика розвитку компетентностей міжкультурної комунікації у процесі вивчення української мови як іноземної / Бакум 3. П., Костюк С. С. // Journal Association 1901 "SEPIKE". - Вип. 19. $-2018 .-$ C. $8-12$.

3. Сдина типова навчальна програма з української мови для студентів-іноземців основних факультетів нефілологічного профілю вищих навчальних закладів України III-IV piвнів акредитації / [Л. І. Дзюбенко, В. В. Дубічинський, С. А. Чезганов та ін.]; за ред. О. М. Тростинської, Н. І. Ушакової. - К. : НТУ «КПІ», 2009. - Ч. 3. - 52 с.

4. Кушнір I. М. Компоненти полікультурної компетентності іноземних студентів / I. М. Кушнір // Викладання мов у вищих навчальних закладах освіти на сучасному етапі. 2008. - №13. - С. 73-78.

5. Рибаченко Л. І. Сучасний стан і основні напрямки реформи системи навчання іноземних громадян в навчальних закладах України / Л. І. Рибаченко. - Донецьк, 2001. - С. 174-178.

6. Сокіл Б. Концепція підготовки фахівців для викладання української мови в іншомовній аудиторії / Б. Сокіл, 3. Мацюк // Концепція підготовки фахівців для викладання української мови в іншомовній аудиторії / Теорія i практика викладання української мови як іноземної : 3б. наук. пр. - Львів, 2006. - Вип. 1. - С. 6-8.

7. Ушакова Н. І. Концепція мовної підготовки іноземців у ВНЗ України / Ушакова Н. І. , Дубичинський В. В., Трос- 
тинська О. М. // Викладання мов у вищих навчальних закладах освіти. Міжпредметні зв'язки : зб. наук. праць. -
Х. : ХНУ ім. В. Н. Каразіна, 2011. - Вип. 19. - С. 136146.

\section{REFERENCES}

1. Bakum Z., Kostiuk S. Methods of intercultural competences development during the Ukrainian language training as a foreign / Bakum Z., Kostiuk S. // Journal Association 1901 "SEPIKE". - Issue 19. - 2018. - P. 8-12.

2. Bakum Z., Ukrainian for foreign students (level C1) : [educational manual] / Bakum Z. P., Horodetska V. A., Sukhovenko N. I. - Kryvyi Rih, 2013. - P. II. - 98 p.

3. General typical educational program of Ukrainian for foreign students of main non-philological departments of higher educational establishments of III-IV accreditation / [L.I. Dziubenko, V. V. Dubichynskyi, S. A. Chezghanov]; edited by O. M. Trostynska, N. I. Ushakova. - K. : NTU «KPI», 2009. - P. 3. -52 p.

4. Kushnir I. M. Components of foreign students' polycultural competence / I. M. Kushnir / Teaching languages in higher educational establishments on the stage. -2008 . - № 13. - P. 73-78.

5. Rybachenko L. I. The current state and main areas of the reform of system of foreign students' education in Ukrainian educational establishments / L. I. Rybachenko. - Donetsk, 2001. - P. 174-178.

6. Sokil B. Conception of specialists training for teaching Ukrainian for foreign students / B. Sokil, Z. Matsuk / The theory and practice of teaching Ukrainian as a foreign language: collected articles - Lviv, 2006. - Issue 1. - P. 6-8.

7. Ushakova N. I. Концепція мовної підготовки іноземців у ВНЗ України / Ushakova N. I., Dubychynskyi V. V., Trostynska O. M.// Teaching languages in the higher educational establishments. Intersubject connections : collected articles. - Kh. : V. N. Karazin Kharkiv National University, 2011. - Issue 19. - P. 136-146.

\section{Development of foreign students' polycultural competence during the Ukrainian language training}

I. A. Dyrda

Abstract. The paper shows the analysis of scientists' views to the definitions of the term "polycultural competence"; peculiarities of foreign students training in Ukraine are emphasized; educational plans, programs and textbooks of the Ukrainian language for foreign students are analyzed; the methodology of development of foreign students' polycultural competence during Ukrainian training is offered; author's educational supplies "Polycultural competence" are analyzed.

Keywords: polycultural competence, foreign students' education, language training, polycultural competence development.

\section{Развитие поликультурной компетентности иностранных студентов в процессе изучения украинского языка}

\section{И. А. Дырда}

Аннотация. В статье раскрыта сущность понятия «поликультурная компетентность»; сделан акцент на особенностях обучения иностранных студентов в Украине; проанализированы учебные планы, программы и ученики украинского языка для иностранцев; представлена методика развития поликультурной компетентности студентов-иностранцев в процессе изучения украинского языка; проанализирован авторское пособие «Поликультурное образование студентов-иностранцев».

Ключевые слова: поликультурная компетентность, обучение иностранных студентов, языковая подготовка, развитие поликультурной компетентности. 


\title{
Essential characteristics of national values in philosophical and psychological and pedagogical literature
}

\author{
O. Z. Glushko \\ Institute of Pedagogy of the National Academy of Educational Sciences of Ukraine, Kyiv, Ukraine \\ Corresponding author. E-mail: glushko.oks74@gmail.com
}

Paper received 11.05.18; Accepted for publication 19.05.18.

\section{https://doi.org/10.31174/SEND-PP2018-170VI70-04}

\begin{abstract}
The article clarifies the essential, general characteristics of the notions of "values" of the "nation" of "national values". The key components of the notion "nation" are determined in the view of the analysis of philosophical and psychological and pedagogical literature. This research is based on the work of world-known philosophers, psychologists, sociologists, educators, and scientists of Ukrainian diaspora.

Keywords: values, national values, nation, objective and subjective features of the nation, Ukrainian diaspora.
\end{abstract}

Introduction. The education of national values relates to a multidimensional scientific and pedagogical problem. On the one hand, in the context of the development of Ukrainian statehood, there is an urgent need to preserve national values and ideals that have been formed and accumulated over the millennial history of Ukrainian people. On the other hand, we live in a global world, the realities of which are multilingualism, multiculturalism, integration at all levels of life; all these processes certainly need new approaches in the education of young people. We want to note that globalization with the formation of a single space, in accordance with generally defined principles of coexistence, of a single normative system, without a doubt, covers all spheres of human activity, including education. At the same time, modern development of society, globalization processes, not only do not deny education on the values of patriotism, national unity. The importance of upbringing of respect for cultural values, traditions, to own history, etc., in conditions of increasing competition between states increases significantly. Thus, the upbringing of a patriot, a citizen of his/her country, which primarily involves the accession to universal and national values, remains an urgent problem today.

Literature review. A significant contribution to the study of value issues was made by national and foreign scholars, in particular, the essence and problems of the origin of values, their classification, problems of values in education were studied by V. Andrushchenko, I. Beh, I. Bychko, M. Kagan, O. Kirichuk, V. Kremen, D. Leontiev, I. Nadolny, V. Ognevyuk, O. Rogova, A. Ruchka, S. Schwartz, V. Vasilenko, etc.

The analysis of the national values of Ukrainian people is made in the works of M. Boryshevsky, S. Krymsky, G. Sitnik, Y. Surmin,V. Vasyutinsky, O. Vishnevsky and others.

The problem of the essence of a nation is highlighted in the works of the Western scholars: B. Anderson, K. Doich, F. Mayneke, E. Renan, E. Renan, E. Smith.

Significant advances in the theory of the concept of "nation", its systematization and classification are the studies of Ukrainian scholars, in particular, the researchers of the Ukrainian diaspora, namely: O. Bochkovskii, G. Vaskovich, G. Kasyanov, A. Kolodiy, I. Kresina, P. Kononenko, V. Lypynsky, I. Mirchuk, Y. Pundika, S. Rudnytsky, V. Starosolsky.

Research methods. In the article the author uses theoretical methods (analysis of scientific sources on the problem of research, synthesis, comparison, generalization).

The concept of a "value". First, let's consider the notion "value", which is central to our study. Actually the notion of a "value" was introduced into philosophical science in the 60's of the 19-th century by German philosopher R. Lotze (1817-1881). At the beginning of the 20-th century, values as a separate branch of research are distinguished in an independent theoretical discipline called "axiology" (from the

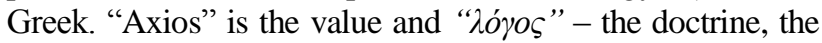
mind, the law).

The German philosopher Friedrich Wilhelm Nietzsche (1844-1900), a representative of irrationalism, features an original look at a person, existing moral and traditional values. In the work "Thus Spoke Zarathustra", he claimed that "God died" "the death of God" and from the realization of this thought begins the process of human revaluation of values [14, p. 9].

In place of the existing values, according to the philosopher, power appears as the main value, or rather, "the will to power". A principle "will to power" is embodied by the human being's will to truth. We should note that for the philosophical doctrine of F. Nietzsche the destruction of traditional values is characteristic, which, according to the philosopher, have already been exhausted. The creation of new values by German thinker was entrusted to a superman. In general, "superman" (Übermensch (German), "Superhuman" (English) - is one of the central concepts of Philosophy F. Nietzsche. "Superhuman" in their actions are not guided by commonly accepted values. It is a person who decides what is good and what is evil. In his concept, the philosopher connects the existence of a superman with the death of God, which in turn leads to the setback from the traditional, Christian values. The change, the destruction of existing values, is associated with the change of those who creates them. The Creator is definitely a Destroyer. On "superhuman", in the philosophical views of F. Nietzsche, is responsible for the creation of the completely new [14, p. 51]. It is the very existence of F. Nietzsche realized as the value of. Consequently, we see that the category of values in the philosophical views of F. Nietzsche is defined as the whole world of being, he advocates the need for a constant reassessment and review of values. The value of life is unconditional, a fundamental value in Nietzsche's philosophy.

Representatives of the Baden School of Neo-Kantianism Wilhelm Windelband (1848-1915) and Heinrich Rickert (1863-1936) founded the theory of values as the basis of their philosophical doctrine. They believed that nature appears on its own, culture - through the creation of values by man. The values were understood as something transcendent, they, according to philosophers, create "independent realm" $[16$, p. 23]. Unlike F. Nietzsche, neo-Kantian H. Rickert believed that values could not change, and the revaluation of all the values that were emphasized by German Philosopher F. Nietzsche, were not the task of science [17, p. 435]. 
One of the founders of sociology Max Weber made a great contribution to the scientific development of value issues (1864-1920). Unlike neo-Kantians, W. Windelband and H. Rickert, who attributed values to the transcendent world, $\mathrm{M}$. Weber considered values as the guiding principles of a particular historical epoch. According to the scholar, cultural ideas and values help to shape society and largely determine human behavior.

Ancient English sociologist Anthony Giddens believes that values are the perception of individuals or groups of people of what is desirable, proper, good or bad. He observes that the values of the individual are formed under the influence of the culture in which he lives [5, p. 669]. Thus, we see a direct connection between values and culture, in particular, the national culture.

American teacher John Dewey (1859-1952), a representative of pragmatism in his work, "Introduction to the philosophy of education", noted that education is a laboratory where philosophic values are specified and verified [3, p. 56]. According to the teacher, every person, due to his personal experience and education, acquires the ability to assess this experience. However, the task of parents and teachers is not only superficial, formally equip the child with the values, but first and foremost try to make them deep into the inner world of the child. Consequently, J. Dewey proclaimed the cult of the child's personality.

The American psychologist Abraham Harold Maslow (1908-1970), a representative of the humanistic approach, identified existential values that determine the meaning of human existence: integrity, perfection, completeness, justice, viability (full functioning), truth, beauty, goodness, selfsufficiency, etc. He believed that values are created or constructed. According to Maslow, values were originally inherent in human nature, they have a biological and genetic basis, but they are also developed by culture and civilization [11, p. 207].

Another representative of humanistic psychology, Carl Rogers (1902-1987), in his work "Learn to be free", advocated freedom of study: in the process of learning in a supportive climate, the student starts to rely on his own values, which he is actually experiencing, and not on those that are imposed by the other people. Thus, with this approach to learning, as the American psychologist and educator C. Rogers believed, the student first learns to be free [18, p. 57-58].

The notion of "nation" in philosophical and psychological-pedagogical literature. From values, let's turn to the consideration of the following concept - the nation. The notion of a nation, as well as the notion of value, is also complex, multicomponent and contradictory. Nation (from the Latin natio - people) the form of the community of people that has historically developed; nations are inherent in the commonality of territory and economic life, the common language, some features of the psychological and spiritual composition, manifested in the originality of culture. However, we want to note that the universal definition of the concept of a nation does not exist. It is difficult to give a complete, comprehensive definition of a nation, because it is a controversial notion.

The study challenges the nation and nation-building were engaged in such well-known Ukrainian Diaspora scientists as O. Bochkovsky, D. Dontsov, A. Knyazhinsky, O. Kulchytsky, V. Lypynsky, Y. Mirchuk, Yu. Pundyk, V. Starosolsky, V. Vaskovych, V. Yaniv whose views are based on theories of nationalism and development of West- ern European and American scientists [7, 9, 10, 20, 23, 24]. The development of the theories of nationalism, the essence of the notion of the nation, its constituent elements were devoted the works of B. Anderson, E. Gellner, É. Durkheim, G. Simmel, F. Meinecke, E. Renan, A. Smith and others.

Our task is to consider such a phenomenon as a nation, to define its characteristic features, first and foremost, to focus on the research of Ukrainian diaspora scholars, as well as to show the influence of foreign scholars dealing with the problems of nation-building, on the views of Ukrainian researchers.

The German philosopher, Johann Gottfried Herder (17441803), described the nation as a linguistic and cultural community. According to Herder, a significant sign of each nation is the language and it was he who gave a significant superiority over other elements that affect the existence and preservation of different distinctive culture [6, p. 40]. He noted that the diversity of languages not only delimits people among themselves, but also encourages them to develop their own cultures. Consequently, J. Herder substantiated the very important idea of the culture-forming function of language which was further developed by linguist W. Humboldt. Historically, the existence of a culture is ensured, as J. Herder believed, primarily through language and tradition, as a mechanism for its historical translation.

The philosopher emphasized the importance of cultural intercourse and the translation of spirituality among nations as the best way to improve the level of art, science, culture and language which in its turn encourages the further development of these peoples.

French scholar Joseph Ernest Renan (1823-1892) in his work "What is a nation?" defined the concept of a nation as a "spiritual principle", a nation from his point of view belongs to the sphere of morality and psychology. In particular, he noted that "the common victories in the past and the joint wishes in the future - these are the main conditions for the formation of a nation ..." [15, p. 118-119]. The definition given by E. Renan is considered to be one of the first classical definitions of the concept of a nation. According to the researcher, the main features of the nation are moral consciousness and will, as opposed to such commonly accepted signs as territory, race, language, religion [15]. Thus, when outlining the concept of a nation, E. Renan emphasizes the priority of subjective rather than objective factors. The value of E. Renan's work "What is a nation?" is that he was the first among researchers who identified the subjective features of the nation clearly.

The German historian Friedrich Meinecke (1862-1954) distinguished the nations as "cultural" that is, ethnic and national "political", state. Moreover, according to F. Meinecke, belonging to a cultural nation, did not depend on state borders, meanwhile belonging to a political nation, was limited by these borders [12, p. 505]. He included the components of a nation: a common territory, a common origin, a common state, a common history, language, religion, national identity. However, this does not mean that in the formation of each nation, all the above features must be present.

One of the renowned researchers of nationalism, Ernest André Gellner (1925-1995), noted the deep-seated interrelation of the nation with culture, which meant "a system of ideas, signs, relationships, behaviors, and communication" [4, p. 297]. In addition to culture, to the main features of the nation Gellner enlisted the territory, language, as well as the mutual recognition of a person belonging to the nation [4]. 
The most well-known classical works of the present, with an original look at the processes of nation-building, include the study of Benedict Anderson's "Imagined Communities". American historian B. Anderson interpreted the nation as "an imagined political community". He thought "the nation was imagined because the representatives of the nation will never know the majority of their compatriots, will not meet and will not even hear anything about them, and yet in the imagination of each will live the image of their ownership" [2, p. 22]. According to Anderson, the language is endowed with the function of nationalization.

German historian Peter Alter claimed it very difficult to give a scientific, generally accepted definition of a nation. In his work "Nation: The Problem of Definition", he described the nation as a "social group", which, on the basis of historical, linguistic, cultural, religious and political connections, realizes its unity and interests $[1$, p. 586]. To the main features of the nation, he attributed national consciousness. In addition, national consciousness, according to P. Altera, is not a kind of constant concept, it can change, as well as values. Thus, certain objective characteristics (territory, state, language, culture, religion, traditions, etc.) are not as much important to the nation, as the awareness of a person, his belonging to one or another nation, the recognition of its uniqueness and distinction from other nations. As P. Alter believed education plays a key role in this process [1].

Now let's look at the views of the Ukrainian scholars who worked on emigration in terms of their conception of a nation, where objective and subjective characteristics include this concept. The conceptual basis for the ideas of the scientists of Ukrainian diaspora on the study of the problems of nationalism, the essence of the concept of "nation", its main components were the works of world-famous philosophers, sociologists and psychologists.

Ukrainian scholar, educator, historian Boris Krupnytsky (1894-1956), as well as P. Alter, believed that the "nation" refers to a complex, "multicolored", multidimensional phenomenon. A nation is, first of all, a spirit, a "spiritual being", and then a biological being [8, p. 157]. Each historical epoch, according to B. Krupnytsky, tend to have its own understanding of the concept of "nation". He stressed the importance and interconnection of culture with the formation of national consciousness. In this context, culture, in terms of emigration, becomes crucial.

According to the writer, one of the ideologues of Ukrainian nationalism, Yuri Pundyk (1918-1973), "nation" is also a very complex, moral imperative, since, as every spiritual phenomenon, it is not subject of rational research. The main characteristic of the nation, in the opinion of the researcher is first of all, the spiritual connection with it, that is, national consciousness but not the territory and blood origin. The traditional definition of a nation, as a historical community of people living in a certain territory and bound together by blood ties, Yu. Pundyk, considered to be narrow. He noted that the nation could exist as a community without territory, but if you look at the USA, there are people of different blood origins [20].

In his work "Ukrainian nationalism" Yu. Pundyk defined the nation as "the family of brothers" [20, p. 57]. These views on the nation of a Ukrainian researcher can be compared with the views of the contemporary American sociologist B. Anderson, who emphasized that the nation "is always perceived as a deep and solidary brotherhood" [2, p. 24]. Thus, it may be noted that Pundyk as well as
Anderson, perceived the nation as something very native, even family-like.

Every person, as Yu. Pundyk believed, is spiritually tied to his nation, whether he lives in his own national environment, or not. This thesis is especially relevant in the conditions of emigration, when a person is physically not in the territory of the settlement of his people, and is outside the Motherland, but spiritually and culturally remains a representative of his nation. Ukrainian scholar referred a language to the main elements of the national affinity that, in his opinion, is an important "means of cementing the spiritual unity of the nation and its preservation". In addition to language, he related historical traditions, spiritual and cultural identity to the leading elements of the nation [20,p.45-46].

Another ideologue of Ukrainian nationalism Viacheslav Lypynsky (1882-1931), also defined the nation as a cultural and spiritual community [10, p. 99]. V. Lypynsky, as well as $\mathrm{Yu}$. Pundyk, considered the main component of the existence of a nation - a common idea and aspiration of the people for state independence [10]. He believed that the formation of a nation happens only through the state. In addition, according to V. Lypynsky, national culture serves as a unifying element for every nation. This thesis about the fundamental importance of culture in identifying a nation can also be found in the works of a famous English researcher on issues of nationalism E. Gellner. Ernest André Gellner, a well-known English researcher on nationalism, adhered to these views of the decisive importance of culture in the formation of the nation.

The Ukrainian educational and public figure Anton Knyazhynsky (1893-1960) in the work "The Spirit of the Nation: Sociological and Ethnopsychological Studio" also determined that culture has a direct influence on the formation of a nation. In his opinion, culture acts as the "most important" sign of the nation [7, p. 67]. Among other features, the researcher distinguished territory, race, traditions, language and faith.

Ukrainian diaspora scientist Volodymyr Yaniv (19081991) described the nation as "the highest holy community". Among other elements, the psychologist attached special importance to the tradition: "The cult of tradition provides the nation eternity" [24, p. 176].

Famous Ukrainian educator, Gregory Vashchenko (18781967), also attributed historical traditions to the main features of the nation. He compared the meaning of traditions in the life of mankind, with the meaning of memory for each person. According to the educator, without traditions further development of mankind would not be possible. In addition, G. Vashchenko concluded that national culture, traditions, as well as language, turn people into nation [24, p. 286]. Consequently, they are the main national formation elements. By definition of G. Vashchenko, the nation creates a community of origin, territory, language, culture, traditions. He also emphasized that the main prerequisite for the existence of the nation is national consciousness, selfidentification with its own ethnic community [22].

Olexander Kulchytsky (1895-1980) is also a prominent Ukrainian philosopher, psychologist, teacher, public figure of the Ukrainian diaspora. The sources of his philosophy were the views of I. Kant and G. Skovoroda. The scientist paid special attention to the issue of nation-building, the formation of the Ukrainian mentality, the study of Ukrainian mentality and character. In particular, he identified racial, geopsychic (geographical), historical, socio-psychic (social), cultural morphological, and psychological factors of the 
formation of Ukrainian nation. The scholar believed that national culture is the main nucleus of belonging to one or another nation. Actually, the national culture, he defined as a synthesis of values and "subjective experiences" [9, p. 22]. $\mathrm{He}$ also highlighted the main features of the nation, which enrolled: 1) the language; 2) religion; 3) culture; 4) a common historical destiny; 5) geopolitical, geographical factors that form the national mentality; 6) common origin; 7) the sense of national messianism. However, according to O. Kulchytsky, among the factors of national unity in the diaspora, religion and culture come to the foreground. At the same time, the connection with the land, that is, the territory, the experience of the common historical destiny, the feeling of a common blood (national affiliation), the language goes to the background $[9$, p. 23]. A well-known Ukrainian diaspora educator Ivan Bondarchuk, analyzing this problem, also noted that language, religion, and national traditions, in the conditions of a foreign language environment and powerful assimilation influence, are the main factors in preserving the ethnic originality of Ukrainians across the borders of the Motherland.

Ivan Ohienko (1882-1972), Metropolitan of the UAOC (Metropolitan Ilarion), a linguist, a teacher, a scientisttheologian considered the language as the main national feature and the main factor of formation the national consciousness of Ukrainians across the borders of the Motherland [13, p. 114]. In terms of emigration, language, as a visible sign of belonging to a certain group acquires a symbolic and moral value. In addition to language, the main features of the nation scientist singled out religion, culture, traditions, customs, and the history of their own people.

Ukrainian scholar, the geographer S. Rudnytsky (18771937), in the work "To the Basics of Ukrainian
Nationalism", published in 1921, defined the "nation" as an integral community of people connected with each other by "peculiar signs" [19, p. 22]. To the signs that form the nation he enlisted: national affiliation (anthropological race), language, culture (both material and spiritual), historical traditions, territory. However S. Rudnytsky, did not distinguish none of the identified features of the nation as the main one in his opinion they were all equivalent [19].

Professor of History Oleksander Shulhyn (1889-1960), also J. J. Russo and F. Minecke believed that there were objective and subjective features of the nation, among them: race, geographic environment, language, culture, religion, state, national consciousness, history. According to O. Shulhyn sense of its national "I" has great importance in the formation of a nation has, that is, national consciousness. As we noted earlier, P. Alter and E. Renan maintained the same point of view when considering the nation. Among the objective features of the nation, the scholar highlighted the language, which he gave the main national-creative function: "... the language became the basis for the creation of Ukrainian nation" [21, p. 287].

Consequently, scientists, in defining the concept of the nation, distinguished objective and subjective features of this phenomenon. Most researchers included race (national origin), state, geographical location or territory, climate, culture, language, historical memory (history), traditions, religion to objective characteristics. Subjective characteristics included: national consciousness, national messianism, freedom. However, none of the above features can be considered vital in the creation of a nation.

When considering the concept of "nation", Ukrainian diaspora researchers singled out the following characteristic features of a nation: (See Table 1).

Table 1

\begin{tabular}{|c|c|c|c|c|c|c|}
\hline Scientists & \multicolumn{5}{|c|}{ Objective features of the nation } & Subjective features of the nation \\
\hline $\begin{array}{c}\text { Anton } \\
\text { Knyazhynsky }\end{array}$ & territory & $\begin{array}{l}\text { origin } \\
\text { (race) }\end{array}$ & language & traditions & $\begin{array}{l}\text { culture, } \\
\text { religion }\end{array}$ & ---- \\
\hline $\begin{array}{l}\text { Oleksander } \\
\text { Kulchytsky }\end{array}$ & territory & $\begin{array}{l}\text { origin } \\
\text { (race) }\end{array}$ & language & history & $\begin{array}{l}\text { culture, } \\
\text { religion }\end{array}$ & national messianism \\
\hline Yuri Pundyk & ----- & --- & language & $\begin{array}{l}\text { historical } \\
\text { traditions }\end{array}$ & $\begin{array}{l}\text { culture, } \\
\text { religion }\end{array}$ & national consciousness \\
\hline $\begin{array}{c}\text { Stepan } \\
\text { Rudnytsky }\end{array}$ & territory & $\begin{array}{l}\text { origin } \\
\text { (race) }\end{array}$ & $\begin{array}{l}\text { language, } \\
\text { literature }\end{array}$ & $\begin{array}{l}\text { traditions, } \\
\text { history }\end{array}$ & culture & national ideology \\
\hline $\begin{array}{l}\text { Oleksander } \\
\text { Shulhyn }\end{array}$ & territory & $\begin{array}{l}\text { origin } \\
\text { (race) }\end{array}$ & language & history & $\begin{array}{l}\text { culture, } \\
\text { religion }\end{array}$ & national consciousness \\
\hline $\begin{array}{c}\text { Gregory } \\
\text { Vashchenko }\end{array}$ & territory & origin & language & traditions & culture & national consciousness \\
\hline
\end{tabular}

Having analyzed the data in the table, we can conclude that when considering the concept of "nation" Ukrainian diaspora scholars identified both objective and subjective attributes. Most researchers ranked the race, geographical location or territory, culture, language, tradition, history, religion to objective factors. Subjective characteristics included national consciousness, national messianism, and freedom.

Conclusion. Consequently, in view of the theoretical approaches and concepts considered in understanding the concept of "nation", it can be noted that this phenomenon is complex and multidimensional. There are different approaches to determining the essence of the nation: some researchers consider it as an ethnic community either as a state or as a social community; others - as an imaginary commu- nity, as a linguistic-cultural community or as a spiritual, "holy" community. We have analyzed in detail the objective and subjective features of the nation, with the emphasis on the research of Ukrainian diaspora scholars, since their scientific achievements have not been sufficiently studied and covered in pedagogical studies.

The article also provides a rather schematic sketch of the evolution of the development and formation of the concepts of value, defined different approaches to understanding the concept of "value" by philosophers, sociologists, and educators. However, an analysis of the concept of "value", the concept of "nation" does not exhaust the fullness of the problem, but they reflect some ideas and understanding about the further consideration of the definitions we examine.

\section{ЛIТЕРАТУРА}

1. Альтер П. Нація: проблема визначення / Петер Альтер 2. Андерсон Б. Уявлені спільноти. Міркування щодо походження // Націоналізм: Антологія / Упоряд. О. Проценко, В. Лісовий. -К.: Смолоскип, 2000. - С. 580-592.

й поширення націоналізму / Бенедикт Андерсон. - Київ: “Критика", 2001.-271 с. 
3. Васькович Г. Об'єктивні і суб'єктивні ознаки нації / Г. Васькович. - Мюнхен. $-1964 .-20$ с.

4. Ващенко Г. Виховання волі і характеру / Г. Ващенко. - К.: “Школяр", 1999. - 385 с.

5. Гердер Й. Мова і національна індивідуальність / Йоган Г. Гердер // Націоналізм: Антологія / Упоряд. О. Проценко, В. Лісовий. - К.: Смолоскип, 2000. - С. 37-45.

6. Геллнер Е. Нації та націоналізм / Ернест Геллнер // Націоналізм: Антологія / Упоряд. О. Проценко, В. Лісовий. - К.: Смолоскип, 2000. - С. 292-310.

7. Гіденс Е. Соціологія / Ентоні Гіденс; [пер. 3 англ. В. Шевкун, А. Олійник]. - К.: Основи, $-1999 .-726$ с.

8. Дьюи Дж. Введение в философию воспитания / Дж. Дьюи. М. $-1921 .-63 \mathrm{c}$.

9. Княжинський А. Дух нації: соціологічно-етнопсихологічна студія / А. Княжинський. - Н-Й - Філадельфія - Мюнхен: Видано Наук. т-вом ім. Шевченка в ЗДА, 1959. - 291 с.

10. Крупницький Б. Історіознавчі проблеми історії України / Б. Крупницький. - Мюнхен: Український Вільний Університет, 1959. - 232 с. [Електронний ресурс]. - Режим доступу: http://diasporiana.org.ua/istoriya/9308-krupnitskiy-bistorioznavchi-problemi-istoriyi-ukrayini-zbirnik-stattey/

11. Кульчицький O. Психодидактичні аспекти українознавчої освіти в діаспорі //Педагогічні проблеми та дидактичні поради (матеріали Вишкільного Курсу для учителів суботніх шкіл). Мюнхен. - Вид-во: УВУ. - 1969. - С. 18-39.

12. Липинський В. Листи до братів-хліборобів // Вишкільний курс / Уложив проф. Г. Васькович. - Брюссель. - Мюнхен. Лондон. - Нью-Йорк. - Торонто: Вид-во СУМ, 1976/77. - Ч 2. - C. 41-117.

13. Маслоу А. Психология бытия / А. Маслоу. - М.: “Рефл-бук”, 1997. $-300 \mathrm{c}$.
14. Майнеке Ф. Загальний погляд на націю, національну державу і космополітизм / Фрідріх Майнеке // Націоналізм: Антологія / Упоряд. О. Проценко, В. Лісовий. - К.: Смолоскип, 2000. C. 503-514.

15. Митрополит Іларіон. Книга нашого буття на чужині. Вінніпег: Українське наукове богословське товариство, 1956. $-167 \mathrm{c}$.

16. Ницше Ф. Так говорил Заратустра / Н. Фридрих; [пер. с нем.]. - М.: Интербук, 1990. - 301 с.

17. Пундик Ю. Український націоналізм /Юрій Пундик. - Париж: Націоналістичне видавництво в Свропі, 1966. - 96 с.

18. Ренан Е. Що таке нація / Ернест Ренан // Націоналізм: Антологія / Упоряд. О. Проценко, В. Лісовий. - К.: Смолоскип, 2000. - С. 107-120.

19. Риккерт Г. Науки о природе и науки о культуре / Г. Риккерт. М.: Республика, 1998. - 413 с.

20. Риккерт Г. Философия жизни / Г. Риккерт; [пер. с нем.]. - К.: "Ника-Центр", 1998. - 512 с.

21. Роджерс К. Вчитися бути вільним / Карл Роджерс // Гуманістична психологія: Антологія /Упоряд. Р. Ткач, Г. Балл. - Т.І. Гуманістичні підходи в західній психології ХХ ст. - К.: "Пульсари", - 2001. -252 с.

22. Рудницький С. До основ українського націоналізму / Степан Рудницький. - 2-ге вид. - Відень - Прага, 1923. - 162 с.

23. Шульгін О. "Нація” і “національність” // Науковий збірник Укр. вільного ун-ту в Мюнхене. Ювілейне видання. Мюнхен: Druck "Logos", 1956. - T. VI. - С. 280-295.

24. Янів В. Нариси до історії української етнопсихології / Упорядкував М. Шафовал. - 2-ге вид. перероб. і доп. К.: Знання, 2006. - 341 с.
1. Alter P. Nation: the problem of definition // Nationalism: Anthology / edited by O. Protsenko, V.Lisoviy. - K.: Smoloskyp, $2000-$ P. 580-592.

2. Anderson B. Imagined Communities. - Kyiv: “Criticism”, 2001. $271 \mathrm{p}$.

3. DeweyJ. Introduction to the philosophy of upbringing.-M.-1921.-63p.

4. Gellner E. Nations and Nationalism // Nationalism: Anthology / edited by O. Protsenko, V. Lisoviy. - K.: Smoloskyp, $2000-$ P. 292-310.

5. Giddens A. Sociology / Per. from English V. Shevkun, A. Oliynyk. - K.: Fundamentals. $-1999 .-726$ p.

6. Herder J. Language and National Identity // Nationalism: Anthology / edited by O. Protsenko, V. Lisoviy. - K.: Smoloskyp, 2000. P. 37-45.

7. Knyazhinsky A. The Spirit of the Nation: Sociological and ethnopsychological studio. - NJ - Philadelphia - Munich: Published by Sci. Shevchenko in the State Duma, 1959. - 291 p.

8. Krupnytsky B. Historical problems of the history of Ukraine. Collection of articles. - Munich: Ukrainian Free University, 1959. - 232 p. [E. resource]. - Access mode: http://diasporiana.org.ua /istoriya/9308-krupnitskiy-b-istorioznavchi-problemi-istoriyiukrayini-zbirnik-stattey/

9. Kulchytsky O. Psychodidactic aspects of Ukrainian-speaking education in the diaspora // Pedagogical problems and didactic advice (materials of the Vocational School for teachers of Saturday schools). -Munich. - Type: Ukrainian Free University. - 1969. P. 18-39.

10. Lypynsky V. Letters to Brothers-Agrarians // school course / edited by prof. G. Vaskovich - Brussels. - Munich. - London. - NJ. Toronto: Published by CYM, 1976/77. - Part 2. - P. 41-117.

\section{ENCES}

11. Maslow A. Toward a psychology of being. - M.: "Refl-Beech", 1997. $-300 \mathrm{p}$.

12. Meinecke F. Cosmopolitanism and the National State // Nationalism: Anthology / edited by O. Protsenko, V. Lisoviy. K.: Smoloskyp, 2000. - P. 503-514.

13. Metropolitan Ilarion. The book of our being in a foreign country. Winnipeg: Ukrainian Scientific Theological Society, 1956. - 167 p. 14. Nietzsche F. So said Zarathustra. - M.: Interbuk, 1990. - 301 p.

15. Renan E. What is a nation? // Nationalism: Anthology / edited by O. Protsenko, V. Lisoviy. - K.: Smoloskyp, 2000. - P. 107-120.

16. Rickert H. About nature science and culture of science. - M.: Republic. $-1998 .-413$ p.

17. Rickert H. Philosophy of life. - K.: "Nika-Center", 1998.-512 p.

18. Rogers C. Freedom to Learn//Humanistic Psychology: Anthology ledited by R.Tkach, G.Ball.-Vol.I.Humanistic approaches in western psychology of the twentieth century.-K.: Pulsari.-2001.-251p.

19. Rudnytsky S. To the basics of Ukrainian nationalism. - 2nd form. - Vienna - Prague, 1923. - 162 p.

20. Pundyk Yu. Ukrainian nationalism. - Paris: Nationalist Publishing House in Europe, 1966. - 96 p.

21. Shulhyn O. "Nation" and "nationality" // Scientific collection Ukr. free un-tu in Munich. Jubilee Edition. - Munich: Druck "Logos", 1956. - T. VI. - P. 280-295.

22. Vashchenko G. Education of the will and character. K.: "School pupil", 1999. - $385 \mathrm{p}$.

23. Vaskovich G. Objective and subjective features of the nation. Munich - 1964. - 20 p.

24. Yaniv V. Essays on the history of Ukrainian ethnopsychology / Arranged M. Shafoval. - 2nd form. processing and add K.: Knowledge, 2006. - 341 p.

\section{Сущностные характеристики национальных ценностей в философской и психолого-педагогической литературе}

\section{О. 3. Глушко}

Аннотация. В статье уточняются сущностные, общие характеристики понятий “ценности”, “нация”, “национальные ценности”. Это исследование основывается на работах всемирно известных философов, психологов, социологов, педагогов, а также ученых украинской диаспоры. Определены ключевые компоненты понятия “нация" исходя из анализа философской и психологопедагогической литературы. На основе анализа психолого-педагогической литературы представителей украинской диаспоры были выделены объективные и субъективные компоненты понятия “нации”.

Ключевые слова: иченности, национальные иенности, нация, объективные и субъективные компоненты нации, украинская duacnopa. 


\title{
Розвиток загальносвропейського багатомовного комунікативного суспільства як соціокультурний чинник модернізації професійної підготовки фахівців з романо-германської філології
}

\author{
Н. Ю. Колесниченко
}

Одеський національний університет імені I.I. Мечникова (Україна, м. Одеса)

Corresponding author. E-mail: 0674853347n@gmail.com

Paper received 11.04.18; Accepted for publication 20.04.18.

\section{https://doi.org/10.31174/SEND-PP2018-170VI70-05}

\begin{abstract}
Анотація. Стаття присвячена обгрунтуванню одного з провідних соціокультурних чинників модернізації професійної підготовки фахівців з романо-германської філології, яким в умовах глобалізації є становлення загальноєвропейського багатомовного комунікативного суспільства. Аналізуються особливості європейської комунікативної інтеграції та способи усвідомлення багатства мовного розмаїття ЄС. Особливої уваги приділено аналізу європейської освітньої політики у сфері вивчення іноземних мов, зокрема, європейької педагогічної конституції, яка зумовила нові вимоги до професійної підготовки фахівців з романо-германської філології як організаторів іншомовної освіти та полікультурного виховання підростаючих поколінь.

Ключові слова: підготовка фахівиів з романо-германської філології, модернізачія професійної підготовки, іншомовна освіта, полікультурне виховання, європейська мовна і освітня політика, європейська комунікативна інтеграція, мультилінгвізм.
\end{abstract}

Вступ. У зв'язку з глобальними змінами в політичному та економічному житті світової спільноти суттєво змінився соціокультурний контекст вивчення іноземних мов. Потреба особистості у швидкій адаптації до умов єдиного інтегрованого світу, розширення міжкультурних контактів у різних сферах людської діяльності спричинили посилення мотивації до вивчення мов міжнародного спілкування, оскільки володіння різними мовами при спілкуванні перешкоджає політичному, економічному та соціальному розвитку. За новітніми даними, мультилінгвізм $є$ поширеним соціокультурним феноменом, бо близько 75\% населення земної кулі володіє тією чи іншою мірою двома або більше мовами [10].

У зв'язку з ситуацією, що склалась, дуже гостро виявила себе проблема формування нового типу особистості - багатомовної і полікультурної, яка вимагає вироблення принципово нового підходу до розуміння іiі ролі в умовах інформаційного суспільства. Це зумовлює необхідність модернізації систем вищої лінгвістичної та іншомовної педагогічної освіти, зокрема оновлення змісту, форм і технологій професійної підготовки фахівців з романо-германської філології як провідних суб'єктів і менеджерів сфер міжкультурної комунікації, іншомовної освіти і полікультурного виховання підростаючих поколінь.

Аналіз основних досліджень і публікацій, ступінь наукового опрацювання проблеми. Вивчення науково-педагогічних джерел засвідчує, що в контексті нових викликів часу та європейської освітньої інтеграції дослідження проблеми підготовки фахівців 3 романо-германської філології залишається методологічно не до кінця осмисленим й теоретично не обгрунтованим належним чином, оскільки розпочалося тільки на початку нового тисячоліття. Серед питань, які привернули увагу українських науковців, варто відзначити наступні: зарубіжний досвід підготовки бакалаврів у європейських та північноамериканських країнах; тенденції розвитку й практика впровадження в країнах Східної Європи та Україні неперервної, ступеневої та іншомовної освіти; особливості реформування університетської освіти лінгвістів та учителів іноземних мов у США та країнах СС.

Попри численну кількість наукових розвідок, які засвідчують про наявність певної теоретично бази дослідження, проблема модернізації професійної підготовки фахівців з романо-германської філології до сьогодні не ставала предметом спеціального й фундаментального науково-педагогічного дослідження, як українських, так і зарубіжних учених-педагогів. Через це в системі їх університетської освіти нами зафіксовано низку суперечностей між: соціально зумовленими зростаючими вимогами сучасного суспільства до фахівців 3 іноземних мов і недостатнім рівнем усвідомлення цих вимог випускниками факультетів романо-германської філології; визначальною роллю бакалаврату в сучасній ринковій економіці та його низьким соціальним статусом в українському суспільстві; станом організації професійної підготовки бакалаврів й магістрів 3 романо-германської філології, зумовленої особливостями традиційного навчального процесу у вищій школі, та їх очікуваннями щодо розширення можливостей практичної реалізації своїх академічних свобод й мобільності згідно нових європейських вимог [3, с. 7].

Мета. 3 огляду на нові виклики часу, мета поданої статті полягає у висвітленні параметрів загальноєвропейського багатомовного комунікативного суспільства як провідного чинника модернізації вітчизняної системи вищої лінгвістичної та іншомовної педагогічної освіти фахівців з романо-германської філології.

Методи. Для досягнення мети застосовано комплекс методів дослідження: теоретичні: аналіз, синтез, систематизація, узагальнення даних філософських i психолого-педагогічних досліджень; аналіз нормативних державних та європейських документів щодо перспектив і чинників розвитку іншомовної освіти, чинних стандартів вищої філологічної та іншомовної педагогічної освіти; аналіз та співставлення освітніх стандартів і програм для виокремлення закономірностей, принципів та педагогічних умов формування конку- 
рентоспроможності майбутніх фахівців з романо-германської філології; педагогічне прогнозування й моделювання; емпіричні: опитування (анкетування, бесіда) для дослідження міри усвідомлення провідними суб' єктами університетської освіти цілей, змісту й якості прикінцевих результатів професійної підготовки майбутніх фахівців з романо-германської філології, організованої на засадах європейської мовної та освітньої політики.

Виклад основного матеріалу. Соціально-політичні та економічні реалії суспільного розвитку впливають не тільки на статус мов, але й на виконувані ними в суспільстві функції. У даний час до таких функцій можна уналежнити наступні: встановлення взаєморозуміння між носіями різних мов і культур; забезпечення соціальної мобільності людини; можливість залучення до світової культури; забезпечення доступу до інформації, у тому числі й за допомогою нових інформаційних технологій. Як показує більш глибокий аналіз документів, які супроводять Болонський процес, iз підписанням у 1992 р. Маастрихтського договору про створення Свропейського Союзу почався якісно новий етап не тільки політичної та економічної інтеграції європейських співтовариств, а й цілеспрямованих заходів стосово зміни європейської освітньої та мовної політики. Останній, особливо в плані вивчення іноземних мов, сприяє окремий напрямок діяльності Сврокомісії - Language Learning Policies як «політика у сфері навчання іноземним мовам", яка ініціювала в 1989 році Першу всеосяжну програму (Lingua). Саме з цього часу «вивчення іноземних мов знаходиться в серці європейських освітніх програм» [8].

Метою нової мовної політики Свропи було передбачено здійснення законодавчої підтримки багатомовності та мовного розмаїття. При цьому подолання мовних і культурних бар'єрів пропонували здійснити не за рахунок прийняття панівної мови як єдиної офіційної та робочої мови Свропейського Союзу, а шляхом відмови від традиційної політики одномовності європейських держав-націй. Використовуючи можливості інформаційного товариства знань, для збереження мовного та культурного розмаїття планували домогтися подолання одномовного менталітету на рівні пересічного громадянина Європейського Союзу. Зокрема, у доповідях Європейської Комісії з питань освіти за 1995 і 1996 рр., відомих як Біла і Зелена Книга, підкреслювали важливість оволодіння європейськими громадянами мовними навичками й уміннями для подолання мовних і культурних бар'єрів, а також необхідність більш плідної участі у створенні Свропейського товариства знань. Як засвідчили заходи 1996 р., активна участь у житті інформаційного товариства неможлива без подолання мономовності шляхом вивчення двох і більше мов упродовж життя. Свропейська комунікативна інтеграція - частина більш глобального процесу європейської інтеграції, мета якої полягає в забезпеченні єдності в умовах культурного та мовного розмаїття. Отже, для подальшого розвитку загальноєвропейського громадського простору, заснованого на цінностях європейської демократії, відповідно до яких існування влади грунтується на вільному обміні думками громадян Європейського Союзу, кожній людині потрібна мова і знання про мову в її культурному та історичному контексті.

Прийняття Свропейським Союзом політики багатомовності та полікультурності в ході інтеграційних процесів зробило можливим здійснення революційних перетворень у національних системах освіти країн-членів на основі Болонського процесу [7]. У зв'язку з цим проблема вивчення й викладання іноземних мов значно актуалізувалася. Вона, виходячи за межі прагматичних цілей та педагогічного виміру, із початку нового тисячоліття стала найважливішою політичною проблемою, яка вимагала розробки та впровадження більш зваженої політики мовної освіти, чому були спеціально присвячені Лісабонська і Барселонська стратегії. Скажімо, Лісабонська Європейська рада (23-24 березня 2000 р.) поставила перед Свропейським Союзом нову стратегічну мету: стати найбільш конкурентоспроможною та динамічною економікою, побудованою на знаннях, здатною на стійке економічне зростання при збільшенні і якісному поліпшенні робочих місць та більш високій соціальній згуртованості. Прийняття відповідної - Лісабонської стратегії розвитку освітніх систем європейських країн ознаменувало початок нового етапу у впровадженні в життя концепції багатомовності, а також мовного та культурного розмаїття. При цьому було підкреслено, що, з одного боку, «мови містяться в серці європейського проекту: вони відображають різні культури і водночас $\epsilon$ ключем до розуміння цих культур» [6, с. 278], а 3 іншого, - «громадяни, які володіють іноземними мовами, можуть скористатися всіма перевагами від вільного пересування по Європейському Союзу, і їм легше звикнути до життя в іншій країні. Мовна компетентність - одна 3 найголовніших умов успішного працевлаштування та кар'єри» [6, c. 279].

Слід зазначити, що Лісабонська стратегія перетворення СС у найбільш конкурентоспроможну і ефективну економіку світу на основі побудови товариства знань та зарахування володіння іноземними мовами до загальної європейської схеми для визначення основних навичок і вмінь була далі підтверджена Барселонським самітом (15-16 березня 2002 р.), що став знаковою подією в межах розвитку європейської мовної політики. Барселонська рада поставила перед СС мету перетворити до 2010 р. європейську систему освіти у всесвітній стандарт якості (world quality reference), програма реалізації якої виокремила як основні три принципи розвитку освітніх систем Свропи: поліпшення якості освіти; полегшення загального доступу до освіти; відкриття освітніх систем для більш широкого міжнародного співробітництва [7].

Зауважимо, що досить успішне втілення в життя плану дій для сприяння вивченню іноземних мов у контексті визнання мовного розмаїття згідно з Барселонською програмою зміцнило позиції багатомовності в освітній та мовній політиці ЄС. Крім того, це сприяло здійсненню Лісабонської стратегії 2000 р., яка охоплювала досягнення стабільної тримовності європейських громадян як частини Концепції вивчення іноземної мови впродовж життя. У цілом, політика Ради Свропи 3 мовної освіти прагне просувати плюрилінгвізм, взаєморозуміння, демократичне громадянство й соціальну єдність. У той час, як досить поширене використання англійської мови вказує на зростаючу лінгвістичну 
єдність, багатомовну освіту вважають необхідною для збереження культурного розмаїття. Зокрема, в основі політики стосовно гармонізації комунікації, спрямованої на взаємне розуміння серед націй Європи, перебуває вимога вивчення громадянами, як мінімум, двох іноземних мов поряд з їх рідними мовами. Зумовлено це тим, що в більш ніж 40 країнах (із різною кількістю носіїв мови, культурним походженням, географічним розподілом тощо) реально використовується більше 80 мов. План дій «Сприяння вивченню іноземних мов та лінгвістичній різноманітності 2004-2006 рр.» був відповіддю Єврокомісії на заклик Європейської ради та Європейського парламенту. Він концентрувався на трьох стратегічних сферах: вивчення іноземних мов протягом життя; поліпшення викладання іноземних мов; створення сприятливого середовища для вивчення мов. План дій включав 47 конкретних пропозицій для дій ЄК протягом 2004-2006 років. Відповідно до нього проводилися:

- загальноєвропейські наукові дослідження, конференції, семінари та інформаційні кампанії, присвячені мовним проблемам;

- спонсорувалося відвідування студентами курсів мовної підготовки;

- надавалися гранти вчителям і викладачам іноземних мов;

- було реконструйовано мовний портал «Свропа»;

- для сприяння вивченню іноземних мов було значно розширено програми Socrates та Leonardo, у які було інвестовано близько 150 млн. євро, що на 66\% більше порівняно з 2000-2002 роками [5, с. 74].

План дій став імпульсом до конкретних кроків у напрямку реформ освітніх систем країн-членів $Є \mathrm{C}$ iз метою запровадження принципу організації навчального процесу «рідна мова плюс дві іноземні мови». Завдяки цьому плану мовна політика стала однією 3 пріоритетних напрямків у нових програмах ЄС на наступні роки [2, с. 145]. Звичайно, не в усіх країнах ці заходи відбуваються 3 однаковою інтенсивністю. Наприклад, вивчення іноземних мов стало інтегральною частиною реформи національної освітньої системи, прийнятої парламентом Болгарії в 2006 році. Зміни в освітній системі відповідно до євроінтеграційної політики плануються у Фінляндії. Уряд Угорщини запровадив всеосяжну стратегію викладання та вивчення іноземних мов під назвою «Світові мови». Цією програмою передбачено підвищення у багато разів фінансування вивчення іноземних мов у школі, запровадження року інтенсивного вивчення іноземної мови у сфері обов'язкової освіти, новий іспит після закінчення школи, збільшення як мінімум на 40\% навчального часу, присвяченого вивченню іноземних мов тощо. Із 2003 року реалізується національна мовна стратегія у Великобританії. Вона передбачає вивчення іноземних мов усіма віковими категоріями громадян, освіту для дорослих та вивчення мов в університетах. У школах запроваджують «Європейські секції», у яких учні зможуть вивчати більше іноземних мов. Деякі 3 цих ініціатив мають форму пілотних проектів, які з часом буде запроваджено в освітні системи. У Німеччині, Нідерландах, Франції, Фінляндії та Австрії запроваджується сертифікат «Сертилінгва», у якому визна- чається мовна компетентність учня. Він доповнюватиме шкільний атестат [5, с. 78].

Визнання важливості доведення до суспільної свідомості європейців тієї ролі, яку відіграє міжкультурний діалог у побудові багатомовного та полікультурного суспільства, призвело Свропейський парламент і раду до прийняття рішення про проведення в 2008 р. Європейського року міжкультурного діалогу. Однією з основних цілей Європейського року міжкультурного діалогу стало сприяння міжкультурному діалогу як процесу, у якому всі мешканці Євросоюзу могли б поліпшити свої здібності й мати справу з більш відкритим, а також більш складним культурним середовищем, у котрому одночасно співіснують різні культурні ідентичності та вірування. Європейський рік міжкультурного діалогу також підкреслив особливу роль освіти та засобів масової інформації як важливих чинників навчання різноманітності, сприяння розумінню інших культур і розвитку навичок, умінь та кращої суспільної практики міжкультурного спілкування. Європейський рік міжкультурного діалогу (2008 р.) продемонстрував важливість збереження культурної спадщини Європи і необхідність підтримки національних культур, особливо культур та мов малих народів. Разом із тим, було усвідомлено, що культурне розмаїття, однак, повинно бути засноване на визнанні загальноєвропейських цінностей і не призводити до самоізоляції та культурної балканізації.

Мовна політика Європейського Союзу, орієнтована на багатомовність, свідчить про надзвичайну важливість вивчення мов в інтеграційних процесах. Перераховані в рекомендаціях основні заходи та принципи спрямовані на розвиток плюрилінгвізму в європейських країнах із метою:

- сприяти всім європейцям у досягненні різних рівнів спілкування на декількох мовах і робити аванси вивченню мов протягом усього життя;

- збільшити кількість досліджуваних мов, спираючись на пропозицію встановити відповідні цілі для кожної мови;

- підтримувати навчальні програми, що використовують гнучкий підхід на всіх рівнях, включаючи основні курси для отримання часткової кваліфікації, ураховуючи їх місце в національній кваліфікаційній системі;

- посилити використання іноземних мов у викладанні нелінгвістичних дисциплін (наприклад, історії, географії, математики), створювати сприятливі умови для такого навчання;

- забезпечити застосування комунікаційних та інформаційних технологій для поширення навчальних матеріалів для всіх національних і регіональних європейських мов;

- стимулювати розвиток зв'язків та обмінів з установами та окремими людьми в інших країнах на всіх рівнях освіти для набуття мовних і культурних звичок на основі автентичного матеріалу [9, с. 74].

Відповідно до сучасних уявлень [1; 5], функціонування мов в СС відбувається на чотирьох рівнях. На першому - публічному інституційному - piвні багатомовність $є$ обов'язкоою, оскільки титульні мови держав, що входять в СС, є основною ознакою їх 
національної ідентичності та самостійності. Усі 23 офіційні мови ЄС рівноправні під час засідань Європейського парламенту, крім того, ними громадяни країн-членів $Є С$ мають право звертатися в різні європейські інстанції і отримувати відповіді на свої запити. Право членів СС виступати на засіданнях Свропарламенту рідною мовою $є$ принципово важливим не тільки з ідеологічної, але і з практичної точки зору, оскільки доповідач чіткіше і яскравіше виражає свої думки, а також витрачає значно менше часу на виступ рідною мовою, ніж нерідною. Невизнання мов може торкнутися почуття національної гідності людей. Обмеження у використанні мов на офіційних засіданнях і в документах ЄC, у діловодстві тощо може послабити позиції країни і в інших проявах. Нарешті, мови, як і прапори країн ЄC під час публічних заходів, виконують знакову функцію. Другий - закритий інституційний - рівень стосується спілкування чиновників і членів різних комітетів на закритих зустрічах, робочих нарадах і т. д. У цьому випадку з розширенням СС і збільшенням кількості офіційних мов, з одного боку, потрібно виявляти повагу до національної мови, а 3 другого, - спілкування відбувається найчастіше англійською, французькою або німецькою мовою. Діяльність допоміжних служб (секретаріатів, груп референтів тощо) здійснюється тільки англійською мовою, що пов'язано з організаційними й фінансовими проблемами. На третьому рівні - спілкування між громадянами всередині рідної країни - проблема не така проста, як здається на перший погляд. Іноземна мова, найчастіше англійська, займає помітне місце при комунікації, зокрема у бізнесі, у сфері високих технологій, у науково-дослідній діяльності й відповідно в наукових публікаціях, в освіті, у спорті, на відпочинку тощо. Рідна мова стає все менш затребуваною. Наприклад, у Данії, Швеції, Нідерландах, Люксембурзі та інших країнах Європи 80\% населення володіє іноземною мовою - англійською. Нарешті, на четвертому рівні, що охоплює спілкування між громадянами СС, які проживають у різних країнах, друга, третя та інші мови необхідні для того, щоб забезпечити просування соціальними сходами, при цьому вибирається та мова, яку, як очікується, будуть вчити всі і яка буде скрізь поширена. Завдяки цьому продовжується поширення англійської мови, i цей процес важко зупинити, оскільки він є результатом не політичних рішень, а добровільного вибору мільйонів громадян із прагматичних міркувань [7, с. 75].

Отже, економічна та політична інтеграція Свропейського Союзу та Лісабонська стратегія на основі рішень Свропейської ради від 2000 р., що поставили за мету «стати найбільш конкурентоспроможною та динамічною економікою, побудованою на знаннях» $[9$, с. 69], відкрили новий етап у впровадженні концепції багатомовності й мовного та культурного розмаїття в життя. Свропейський рік мов 2001 р., а також інші єв- ропейські роки, зіграли вирішальну роль у зміні суспільної свідомості на користь багатомовності та мовного розмаїття, а також у забезпеченні широкої підтримки для прийняття законодавчих заходів у галузі мовної освіти з метою виховання нового багатомовного покоління європейських громадян, які володіють крім рідної мови, не менш, ніж двома іноземними мовами. Зокрема, ціннісним орієнтиром європейської університетської освіти фахівців з романо-германської філології став феномен «Професіоналізм учителя-європейця» (Ф. Ваніскотт), який передбачає, що головними стратегіями його успішної діяльності є: автентичність, виключність, візуалізація знань, демократичність, діалогічність, дослідництво, інтегративність, конструктивізм, лідерство, особистісна зорієнтованість, послідовність, рефлективність, здатність до розвитку соціальна спрямованість, спирання на відповідний досвід, співробітництво, цілеспрямованість [4]. Це вказує на зсув основного акценту в ролі європейського вчителя як провідного суб' єкта іншомовної освіти з позиції виконавця іiї функцій (урокодавець) на «рефлексуючого практика» (творця полікультурної мовної особистості учня), що припускає актуалізацію полікультурних і творчих аспектів його педагогічної діяльності в сфері іншомовної освіти та полікультурного виховання молоді.

Висновки. Таким чином, з огляду на означене вище, очевидно, модернізація вітчизняної системи професійної підготовки фахівців з романо-германської філології в умовах розвитку багатомовного комунікативного європейського суспільства передусім передбачає оновлення й приведення цілей і завдань, змісту і методів, форм і технологій їх навчання у відповідність із сучасними суспільними і науковими вимогами, властивими етапу європейської освітньої інтеграції. Цьому, на нашу думку, сприятиме розробка нових концептуальних моделей випускників спеціальностей 035.02 «Філологія. Германські мови» та 035.05 «Філологія. Романські мови», а також впровадження інноваційних технологій та засобів студентоцентрованого навчання. Через це університетським вченим доцільно більш активно розробляти й впроваджувати в освітній процес новітні моделі підготовки європейських вчителів іноземних мов і культур, яким притаманні полікультурність, толерантність, миролюбність, інноваційність, креативна спрямованість.

Загалом, становлення й інтенсивний розвиток загальноєвропейського багатомовного комунікативного суспільства зумовлюють необхідність системної модернізації професійної підготовки фахівців з романо-германської філології у напряму набуття ними не тільки провідних ознак європейських учителів іноземних мов, але й медіаторів культур в сфері міжкультурної комунікації, іншомовної освіти та полікультурного виховання.

\section{ЛІТЕРАТУРА}

1. Загальноєвропейські рекомендації 3 мовної освіти: вивчення, викладання, оцінювання / пер. $з$ анг., під ред. С.Ю Ніколаєвої. - К.: Ленвіт, 2003. - 273 с.

2. Загорулько Л. П. Языковое образование в современных условиях : социально-философский анализ : дис. ... канд. философ. наук : 09.00.11 / Любовь Петровна Загорулько. Новосибирск, 2011. - 141 с. 
http://svitovid6.webnode.com.ua/news/pedagogichnakonstitutsiya-jevropi/

5. Смокотин В. М. Основные инструменты политики многоязычия и поликультурности в Европе: общие европейские языковые компетенции и языковой портфель / В.М. Смоткин // Вестник Томского государственного университета - Томск: ТГУ, 2010. - № 37. - С. 72- 77.

6. Breidbach S. European Communicative Integration: The Function of Foreign Language Teaching for the Development of a European Public Sphere (2013) [Language, Culture and Curriculum]. Vol. 15, N 3. P. 275- 279.
7. The Bologna Declaration on the European space for Higher education an explanation (1999). Bologna. $10 \mathrm{p}$.

8. Tuning Educational Structures in Europe (2006). [EC : Educational and Culture. Socrates-Tempus]. - [Електронний pecypc] : - Режим доступу : http://www.eua.be/eua/en/projects_ects.jspx.

9. Tudor J. The Challenge of the Bologna Process for Higher Education Language Teaching in Europe (2005). Brussels: Universite Libre de Bruxelles. 178 p.
1. Nikolaiva S. Yu. (Ed.) (2003) Zagalnoyevropeiski rekomendatsii z movnoyi osvity: vyvchennia, vykladannia, otsiniuvannia [Common European framework of reference for languages: learning, teaching, assessment]. Kyiv.

2. Zagorulko L. P. (2011) Yazykovoie obrazovaniie v sovremennykh usloviiakh: sotsialno-filosofskii analiz [Linguistic education under contemporary conditions: social and philosophical analysis]. Extended abstract of candidate's thesis [in Novosibirsk, Russia]

3. Kolisnechenko N. Yu. (2014) Profesiina pidgotovka bakalavriv romano-germanskoi filologii v systemi universytetskoi osvity: teoretychni i metodychni zasady [Romance-Germanic philology bachelors professional training in the higher education system: theoretical and methodical basis] Monograph. Odesa.

4. Pedagogichna konstytutsiia Yevropy [Pedagogical Constitution of Europe]. Retrieved from URL: http://svitovid6.webnode.com.ua/news/pedagogichna-konstitutsiyajevropi/ [in Ukrainian]

5. Smokotkin V. M. (2010) Osnovnyie instrumenty politiki

\section{EFERENCES}

mnogoiazychiia I polikulturnosti v Yevrope: obshchiie yazykovyie kompetentsyi I yazykovoi portfel [The main means of plurilingualism and polyculturalism policy in Europe: common European linguistic competences and language portfolio] The Bulletin of Tomsk State University (pp. 72-77). Tomsk.

6. Breidbach S. European Communicative Integration: The Function of Foreign Language Teaching for the Development of a European Public Sphere (2013) [Language, Culture and Curriculum]. Vol. 15, N 3. P. 275-279.

7. The Bologna Declaration on the European space for Higher education an explanation (1999). Bologna. $10 \mathrm{p}$.

8. Tuning Educational Structures in Europe (2006). [EC : Educational and Culture. Socrates-Tempus]. - [Електронний ресурс] : - Режим доступу: http://www.eua.be/eua/en/projects_ects.jspx.

9. Tudor J. The Challenge of the Bologna Process for Higher Education Language Teaching in Europe (2005). Brussels: Universite Libre de Bruxelles. 178 p.

\section{The development of a pan-European multilingual communicative society as a socio-cultural factor in the modernization of the professional training of specialists in the field of Romance-Germanic philology}

N. Yu. Kolesnichenko

Abstract. The article is devoted to the substantiation of one of the most important factors in the modernization of professional training of specialists in Romance-Germanic philology, that is the formation of a pan-European multilingual communicative community. The specifics of the European communicative integration and ways of understanding the treasures of the linguistic diversity of the European Union are analyzed. Particular attention is paid to the analysis of the new European educational policy in the field of foreign languages, in particular, the European pedagogical constitution that proclaimed a list of new requirements for professional training of specialists in the field of Romance-Germanic philology as organizers of foreign language education and multicultural education for the younger generations. It is demonstrated that the European language and educational policy is focused on multilingualism and multiculturalism. It illustrates the vital importance of modernizing the professional training of specialists in Romance-Germanic philology as organizers of foreign-language education and multicultural education of the younger generations that should practically introduce measures and principles aimed at the development of plurilingualism in the European countries in order to help all Europeans to achieve different levels of communication in several languages throughout their lives; to support curricula that use a flexible approach to the study of foreign languages and cultures; to strengthen the use of foreign languages in teaching non-linguistic disciplines (history, geography, mathematics) creating favourable conditions for such training; to ensure the use of communication and information technology for the dissemination of teaching materials for all national and regional European languages; encourage the development of relationships and exchanges with institutions and individuals in other countries at all levels of education for the acquisition of linguistic and cultural habits based on the authentic material.

Keywords: training of specialists in the field of Romance-Germanic philology, modernization of professional training, language learning, European linguistic and educational policy, European communicative integration, multilingualism.

Развитие общеевропейского многоязычного коммуникативного сообщества как социокультурный фактор модернизации профессиональной подготовки специалистов в области романо-германской филологии

\section{Н. Ю. Колесниченко}

Аннотация. Статья посвящена обоснованию одного из важнейших факторов модернизации профессиональной подготовки специалистов по романо-германской филологии, каким является становление общеевропейского многоязычного коммуникативного сообщества. Анализируется специфика европейськой коммуникативной интеграции и способы осознания богатства языкового разнообразия ЕС. Особое внимание уделяется анализу новой европейской образовательной политики в сфере иностранных языков, в частности, европейской педагогической конституции, провозгласившей перечень новых требований к профессиональной подготовке специалистов в области романо-германской филологии как организаторов иноязычного образования и поликультурного воспитания подрастающих поколений.

Ключевые слова: подготовка специалистов в области романо-германской филологии, модернизация профессиональной подготовки, иноязычное образование, европейская языковая и образовательная политика, европейская комуникативная инеграиия, мультилингвизм. 


\title{
Забезпечення якості вищої освіти в Україні: виклики сьогодення
}

\author{
A. В. Куруч \\ Українська інженерно-педагогічна академія \\ Corresponding author. E-mail: Anutakuruch@ukr.net
}

Paper received 21.05.18; Accepted for publication 28.05.18.

\section{https://doi.org/10.31174/SEND-PP2018-170VI70-06}

\begin{abstract}
Анотація. У роботі розглядаються проблемні питання забезпечення якості освіти у вищих навчальних закладах України в контексті вимог Законів України «Про освіту» і «Про вищу освіту». Матеріал надано згідно з групами характеристик: якість потенціалу досягнення мети освіти, якість процесу формування професіоналізму і якість результату освіти. У роботі доведено необхідність вирішення питання надання якісних освітніх послуг у ВНЗ України з позицій системного підходу шляхом створення певної «дорожньої карти» як з боку держави, так і самих вищих навчальних закладів. Особливий акцент зроблено на проблемах поліпшення мотивації учасників навчального процесу у ВНЗ, забезпеченні індивідуальних траєкторій розвитку для кожного студента, подальшому вдосконаленні нормативно-правової бази вищої освіти. Значна увага приділена також використанню інформаційних технологій у навчальному процесі, особливо необхідності врахування можливостей сучасних гаджетів тощо. Питання забезпечення надання якісних освітніх послуг безпосередньо пов'язуються з реалізацією компетентнісної парадигми у навчанні.
\end{abstract}

Ключові слова: вищий навчальний заклад, компетентнісний підхід, професійна підготовка, професорсько-викладачький склад, якість освіти, якість освітнього процесу.

Актуальність дослідження і постановка проблеми. Система освіти в Україні знаходиться на шляху активних перетворень, що обумовлено з одного боку реформуванням іiї зверху, за рахунок введення в дію нової нормативно-правової бази, а саме Законів України «Про вищу освіту» (2014), «Про освіту» (2017), з іншої - орієнтацією на національні освітні системи розвинених країн світу, що активно розвиваються в епоху глобалізації. Ринок освітніх послуг сьогодні суттєво комерціалізований. Одним із впливових чинників на ньому в умовах пошуку конкурентних переваг $є$ якість освітніх послуг, що надається у вищій школі. Саме тому забезпечення якості вищої освіти у ВНЗ України є пріоритетним завданням на сучасному етапі. Разом із тим у багатьох джерелах ця проблематика розглядається тільки в площині удосконалення навчального процесу, що не відповідає вимогам часу.

Аналіз досліджень та публікацій.

Початок XXI століття характеризується активним включенням України у глобалізаційні процеси в сфері освіти. Їх каталізатором стало підписання Україною у 2005 році Болонської угоди. Саме з цього часу українські науковці оприлюднюють низку робіт, які стосуються якості освіти. Це роботи Т.Борової, І. Булах, Л. Гриневич, С. Клепка, О.Коваленко, К. Корсака, В. Кременя, К. Левківського, О. Локшиної, В. Лугового, Т. Лукіної, О. Ляшенка, О. Овчарук, Л. Паращенко, Г.Полякова та ін.

У цей же період часу відбувається захист низки дисертаційних досліджень щодо забезпечення якості вищої освіти. Це роботи М.Кісіля «Якість вищої освіти як предмет філософського аналізу»; В.Лунячека «Теоретико-методологічні засади професійної підготовки керівних кадрів в умовах магістратури до управління якістю освіти»; І.Потай «Моделі і структура мультипроекта модернізації системи управління якістю підготовки спеціалістів з вищою освітою»; В.Радченко «Управління якістю професійної діяльності викладачів вищих навчальних закладів I-II рівнів акредитації»; I. Трегубенко «Методи та моделі оптимізації системи управління навчальним процесом в вищих закладах освіти» та ін. Однак слід зазначити, що їх відсоток серед педагогічних досліджень є досить невеликим, що свідчить про необхідність подальших наукових досліджень за цим напрямом.

Міжнародний стандарт ISO 8402-86 визначає якість як сукупність властивостей і характеристик продукції чи послуги, які надають їм здатність вдовольняти обумовлені чи передбачені потреби [10, с. 427]. Взагалі ж освіта як послуга знайшла своє відображення в Генеральній угоді з торгівлі послугами («General Agreement on Trade in Services»- «GATS»), що обумовило іiі комерціалізацію [11].

Енциклопедія освіти за ред. В.Кременя визначає якість освіти, як збалансовану відповідність певного освітнього рівня (загальної середньої, професійнотехнічної, вищої тощо) численним потребам, цілям, умовам, затвердженим освітнім нормам і стандартам, яка встановлюється для виявлення причин порушення цієї відповідності та управління процесом поліпшення встановленої якості [3].

О.Ляшенко вважає якість освіти квінтесенцією: 1) сутності поняття; 2) процедур діагностування; 3) аналізу явищ і властивостей суб'єктів освітнього процесу [6, с. 10].

Закон України «Про освіту» (ст.1), визначає якість освіти як відповідність результатів навчання вимогам, встановленим законодавством, відповідним стандартом освіти та/або договором про надання освітніх послуг. Крім того, в документі надається визначення якості освітньої діяльності, як рівню організації, забезпечення та реалізації освітнього процесу, що забезпечує здобуття особами якісної освіти та відповідає вимогам, встановленим законодавством та/або договором про надання освітніх послуг [9]. У ст.1 Закону України «Про вищу освіту» поняття «якість освітньої діяльності» уточнюється і визначається як рівень організації освітнього процесу у закладі вищої освіти, що відповідає стандартам вищої освіти, забезпечує здобуття особами якісної вищої освіти та сприяє створенню нових знань[7].

Слід зазначити, що зміни певних акцентів у поглядах на якість вищої освіти відбулися в процесі запровадження в навчальний процес українських ВНЗ компе- 
тентнісної парадигми, основні положення якої відображені в роботах таких українських науковців як М.Астахова, Н.Бібік, Г.Дегтярьова, В.Мадзігон, О.Пометун, С.Раков, З.Рябова, О.Савченко, С.Сисоєва, Т.Сорочан та ін. Їх увага переважно приділена якості формування певних компетентностей в процесі професійної підготовки у вищій школі і системі підвищення кваліфікації.

В.Лунячек вважає, що для поліпшення ситуації необхідно запровадити жорсткі вимоги до професійної компетентності керівників освітньої галузі як на момент їх призначення, так і в процесі роботи. Потрібно регулярно проводити їх професійну атестацію незалежними комісіями, до яких повинні входити не тільки представники органів управління, а й представники педагогічної науки і громадськості. Саме якість керівного складу ВНЗ і органів управління освітою є однією 3 необхідних умов надання якісних освітніх послуг в Україні [5].

Сьогодні можна стверджувати, що суттєві зміни в поліпшенні якості освіти в ВНЗ України почали відбуватися після затвердження Національної рамки кваліфікацій України (2011), Закону України «Про вищу освіту» (2014), Закону України «Про освіту» (2017), завдяки положенням яких фактично було сформульована «дорожня карта» для ВНЗ України [7-9].

Разом із тим проведений нами аналіз свідчить про необхідність подальших науково-теоретичних пошуків у цій царині в контексті новітніх змін у освітньому законодавстві України.

Постановка завдання. Метою цієї роботи є розгляд основних проблем щодо забезпечення якості вищої освіти у ВНЗ України з урахуванням вимог оновленої нормативно-правової бази, що регламентує діяльність системи освіти на сучасному етапі.

Виклад основного матеріалу.

Створення систем внутрішнього і зовнішнього забезпечення якості надання освітніх послуг у ВНЗ України на сучасному етапі базується на ст.41 Закону України «Про освіту», яка визначила, що складовими системи забезпечення якості освіти є:

-система забезпечення якості в закладах освіти (внутрішня система забезпечення якості освіти);

-система зовнішнього забезпечення якості освіти;

-система забезпечення якості в діяльності органів управління та установ, що здійснюють зовнішнє забезпечення якості освіти [9].

Відповідні положення уточнені також у ст. 16 Закону України «Про вищу освіту», яка вказує, що система забезпечення якості вищої освіти складається з системи внутрішнього забезпечення якості освіти у ВНЗ; системи зовнішнього забезпечення якості освітньої діяльності вищих навчальних закладів та якості вищої освіти; системи забезпечення якості діяльності Національного агентства із забезпечення якості вищої освіти і незалежних установ оцінювання та забезпечення якості вищої освіти [7].

У процесі підготовки цієї роботи ми виходили з поглядів Е.Короткова, який пропонує розглядати якість освіти, як комплекс характеристик освітнього процесу, що визначає послідовне і практично ефективне формування компетентності і професійної свідомості. Він виділяє три групи характеристик: якість потенціалу досягнення мети освіти, якість процесу формування професіоналізму і якість результату освіти. При цьому якість потенціалу включає якість мети освіти; якість освітнього стандарту; якість освітньої програми; якість матеріально-технічної бази освітнього процесу, якість професорсько-викладацького складу; якість абітурієнтів або учнів; якість інформаційно-методичної бази.

Якість процесу формування професіоналізму складається $з$ якості технології освіти; якості контролю навчального процесу; якості мотивації викладацького складу на творчість і ефективність педагогічної роботи; якості відношення учнів (студентів) до освіти; інтенсивності освітнього процесу; управління освітою; методів презентації знань тощо.

Під якістю результату освіти Е. Коротков розуміє усвідомлення професіоналізму; розпізнавання i реалі-зація індивідуальних здібностей і особливостей; праце-влаштування; кар'єру і зарплату; оволодіння методоло-гією самоосвіти; знання; практичні навички [4, с.77-80].

Виходячи 3 викладеного вище, розглянемо можливості забезпечення якісного надання освітніх послуг у ВНЗ України. Щодо постановки мети освіти, то слід зауважити, що більшість закладів освіти ставлять перед собою амбітні цілі, виходячи $з$ викликів ринку праці і практики провідних ВНЗ світу, які посідають провідні місця у основних світових рейтингах. Водночас подальшої роботи потребує формування стандартів освітньої діяльності у вищій школі. Згідно з ст.9 Закону України «Про вищу освіту», стандарт освітньої діяльності - це сукупність мінімальних вимог до кадрового, навчально-методичного, матеріально-технічного та інформаційного забезпечення освітнього процесу закладу вищої освіти і наукової установи [7]. Порівняння змістовного наповнення стандартів за спеціальностями свідчить про певну їх неузгодженість, що потребує подальшої кропіткої роботи фахівців високого класу.

Окремо слід наголосити на забезпеченні якості освітніх програм. Якщо їх тематичне наповнення за багатьма спеціальностями в цілому є досить уніфікованим, то змістовне наповнення окремих тем в результаті має певні, а іноді суттєві відмінності. Це пов'язано безпосередньо з якістю професорсько-викладацького складу і вимогами до нього на рівні конкретного ВНЗ. У безпосередньому зв'язку із змістовним наповненням освітніх програм, особливо за технічними спеціальностями, є якість матеріально-технічної бази. Систематичне недофінансування освіти за останні десятиріччя призвело до суттєвого погіршення стану лабораторної бази, що утруднює підготовку фахівців за цілою низкою спеціальностей. У сьогоднішніх умовах проблема може бути вирішена тільки поступово за рахунок цільового фінансування окремих напрямів. Слід також наголосити, що відповідне фінансування повинно відбуватися як $з$ державного і місцевого бюджету, так і з боку недержавних (в тому числі приватних) внутрішніх інвесторів. Залучення закордонних інвесторів в умовах жорсткої конкуренції на ринку вищої освіти є сьогодні проблематичним.

Необхідно також звернути увагу на IT-забезпечення навчального процесу. До цього часу актуальним є питання забезпечення навчального процесу сучасними комп'ютерами і відповідними прикладними програма- 
ми. Сьогодні значна кількість діючого у ВН3 комп'ютерного парку не взмозі за своїми технічними характеристиками використовувати програмне забезпечення останнього покоління. Навчальний процес у ВН3 не передбачає системне використання гаджетів. Тільки частина ВНЗ України вирішила питання надання для студентів безкоштовного WI-FI у навчальних корпусах і гуртожитках.

Сучасний рівень інформатизації безпосередньо впливає і на якість інформаційно-методичної бази навчального процесу в цілому. Тільки бібліотеки провідних ВНЗ України мають досить досконалу систему електронних каталогів і спроможні управляти навчальним процесом з використанням сучасних інформаційних технологій.

Залишається актуальною проблема якості професорсько-викладацького скаладу у ВНЗ України, що грунтовно розглянуто в роботах Н.Батечко, К.Астахової та iн [1-2]. Зокрема у роботі Н.Батечко вказується, що незважаючи на загальну тенденцію зменшення основної кількості викладацького складу вищих навчальних закладів України за останні роки, простежується зростання чисельності як кандидатів та докторів наук, доцентів та професорів [2]. Темпи отримання звань доцента і професора знизилися після більш жорсткого нормативно-правового регулювання на загальнодержавному рівні. Водночас залишається достатньо низьким науковий рівень захищених в Україні кандидатських і докторських дисертацій, відповідальність спеціалізованих вчених рад за ці процеси не є адекватною.

Не в рівних умовах знаходяться ВНЗ України і з позиції якості абітурієнтів. Сьогодні існує чітка їх стратифікація у залежності від результатів зовнішнього незалежного оцінювання (ЗНО). Випускники шкіл із вищими балами ЗНО обіймають місця у провідних університетах. Таким чином студенти першого курсу $є$ суттєво різними за своїм базовим потенціалом у різних ВН3, що також впливає на якість освіти і як результат на підготовку фахівця і його конкурентоспроможність на ринку праці, що безпосередньо пов'язано з наступною групою характеристик якості вищої освіти, а саме якістю формування професіоналізму.

В цілому технології навчального процесу у вищій школі є традиційно застарілими і передбачають проведення лекцій і лабораторних робіт традиційними методами. Традиційними залишаються також і методи презентації знань тощо. Неупереджений аналіз свідчить, що педагогічні технології, які можна побачити за результатами запиту «Педагогічні технології вищої школи» у пошуковій системі GOOGLE, переважно пов'язані із застосування IT-технологій і систем дистанційного навчання. Значно меншими є напрацювання інноваційних підходів, пов'язаних із застосуванням інтерактивних методів навчання, особливо це стосується проектного підходу. В Україні немає сьогодні практики розповсюдженої у низці провідних університетів світу щодо, наприклад, перебудови навчального процесу в магістратурі на проектній основі, що дає можливість підготувати фахівця принципово іншої якості.

Переважно традиційним залишається і контроль якості навчального процесу. Сьогодні переважна більшість ВНЗ згідно з діючим законодавством уже затвердила положення про створення внутрішніх систем оцінювання якості освіти, однак практична їх реалізація залишилася традиційною. Досить важко відбувається процес трансформації традиційного контролю у систему моніторингових процедур, які б системно відстежували навчальний процес за певними показниками, що стосуються як студентів, так і викладачів. Особливу увагу потрібно приділити індивідуалізації моніторингу, його прив'язці до систем рейтингування, систем корекції і прийняття управлінських рішень керівництвом ВНЗ.

Обмеженою сьогодні є можливість мотивації професорсько-викладацького складу щодо поліпшення ефективності педагогічної роботи. Фінансові можливості обмежені певними видами доплат, що регламентуються застарілою нормативно-правовою базою в цьому питанні. Обмеженою $є$ також можливість якісного підвищення кваліфікації, особливо закордонних стажувань, фінансування яких сьогодні не передбачено. Певні виключення відбуваються тільки за рахунок закордонних грантодавців.

Негативним чинником впливу на якість освіти $є$ нігілізм частини студентів щодо їх ролі у навчальному процесі ВНЗ і можливостей подальшого працевлаштування. Разом із тим багато студентів відвідують навчальні заняття частково, у зв'язку із складним матеріальним становищем і необхідністю паралельно працювати для отримання коштів на своє існування.

Сума перелічених вище чинників заважає інтенсифікації навчального процесу як умови надання якісної освіти.

Слід також зауважити, що дуже повільна модернізація методів управління системою вищою освіти потребує свого каталізатора. Це стосується і реальної автономії ВН3, кадрової політики щодо їх керівного складу, оцінювання результатів роботи тощо.

Виходячи $з$ викладеного вище, складним є процес усвідомлення випускниками ВНЗ свого професіоналізму. Розповсюдженою залишається тенденція відсутності прямого зв'язку між отриманою вищою освітою і першим робочим місцем, що частково формалізує отриману випускниками освіту. Низький рівень індивідуалізації навчального процесу, пов'язаний з одного боку 3 фінансовими чинниками, які не дозволяють організовувати навчальний процесу у малих групах, а частково 3 неготовністю вищої школи підготувати значну кількість спецкурсів індивідуально прив'язаних до конкретного студента.

Для випускника сучасного ВНЗ актуальною є рівень заробітної плати на першому робочому місці, особливо в бюджетній сфері, що також не сприяє мотивації до навчання. Достойний рівень заробітних плат сьогодні ми маємо переважно в IT-галузі, частина представників якої працює без офіційного оформлення. Актуальною проблемою $є$ також перетікання кращих випускників ВН3 у магістратури закордонних ВН3 і $з$ наступним працевлаштуванням у зарубіжних країнах.

Нарешті слід зауважити, що суттєвою проблемою забезпечення якості вищої освіти в Україні $є$ дотримання академічної доброчесності. Основні положення цього процесу нарешті унормовані положеннями Закону України «Про освіту», зокрема ст.42, де сказано, що «академічна доброчесність - це сукупність етичних принципів та визначених законом правил, якими мають 
керуватися учасники освітнього процесу під час навчання, викладання та провадження наукової (творчої) діяльності з метою забезпечення довіри до результатів навчання та/або наукових (творчих) досягнень» [9]. Передбачена також відповідальність за порушення академічної доброчесності педагогічними, науковопедагогічні та наукові працівники закладів освіти та здобувачами.

Виходячи із викладеного вище, зробимо такі висновки:

1. Забезпечення суттєвого поліпшення якості вищої освіти в Україні потребує системного підходу, зокрема за рахунок подальшої реалізації програм розвитку ВНЗ 3 урахуванням наведених у роботі чинників, що потребує з одного боку змін у ментальності професорськовикладцького складу і керівництва ВНЗ, 3 іншого подальших кроків з боку державної влади.

2. Низка висвітлених у роботі проблем потребує суттєвих змін у фінансуванні вищої освіти і може бути вирішена тільки за умови економічного зростання в Україні, яке в свою чергу пов'язано з якістю підготовки фахівців.

3. Поліпшення якості освітнього процесу у ВНЗ потребує перегляду низки фінансових і організаційнокадрових механізмів у сфері вищої освіти, що зрушить ситуацію у позитивному напрямі.
4. Забезпечення якості вищої освіти можливе лише за умови дотримання академічної доброчесності згідно 3 діючим законодавством, що потребує як зміни ментальної складової учасників навчального процесу у ВН3, так і поліпшення технічного забезпечення цього процеcy.

5. Доцільним $є$ проведення низки науковокомунікативних заходів щодо обговорення механізмів реалізації окремих складових систем управління якістю у ВН3.

6. Подальшого розвитку потребує мотивація якісної роботи професорсько-викладацького складу як ключової складової інноваційних перетворень.

7.Додаткової уваги потребує розвиток індивідуальності учасників навчального процесу у ВНЗ. Це рівною мірою стосується і викладачів, і студентів. Тільки розвиток кожного окремого індивіда, як креативного суб'єкта, що отримує якісні освітні послуги, створить умови для позитивних перетворень в Україні.

Перспективи подальших досліджень. До перспективних напрямів досліджень даної проблематики ми відносимо розробку окремих механізмів забезпечення якості вищої освіти у відповідності до світових стандартів.

\section{ЛІТЕРАТУРА}

1. Астахова Е. В. Кадровый корпус высшей школы Украины: метаморфозы развития : монография / Е. В. Астахова ; Народ. укр. акад. [каф. истории Украины]. - Х. : Изд-во НУА, 2006. $-188 \mathrm{c}$.

2. Батечко Н.Г. Сучасний склад розвитку кадрового потенціалу вищої школи України / Н.Г.Батечко [Електронний ресурс]. - Режим доступу: http://www.irbisnbuv.gov.ua/cgibin/irbis_nbuv/cgiirbis_64.exe?C21COM=2\&I21DBN=UJRN $\&$ P21DBN=UJRN\&IMAGE_FILE_DOWNLOAD=1\&Image _file_name=PDF/pptp_2013_3_3.pdf

3. Енциклопедія освіти / АПН України ; [голов. ред. В. Г. Кремень]. - К. : Юрінком Інтер, 2008. - 1040 с.

4. Коротков Э. М. Управление качеством образования : учеб. пособие для вузов / Э. М. Коротков. - М. : Академ. Проект ; Мир, 2006. - 320 с.

5. Лунячек В. Е. Підготовка магістрів державного управління до забезпечення якості освіти: теорія та практика : монографія / В. Е. Лунячек. - Х. : ХНУ імені В. Н. Каразіна, 2011. $-372 \mathrm{c}$.

6. Моніторинг якості освіти: світові досягнення та українські перспективи / за заг. ред. О. І. Локшиної. - К. : К.І.С., 2004. $-128 \mathrm{c}$.

7. «Про вищу освіту» Закон України [Електронний ресурс]. Режим доступу: http://zakon5.rada.gov.ua/laws/show/ru/155618

8. Про затвердження Національної рамки кваліфікацій України : постанова Кабінету Міністрів України від 23 листоп. 2011 p. № 1341 [Електронний ресурс]. - Режим доступу : http://zakon2.rada.gov.ua/laws/show/ 1341-2011-\%D0\%BF.

9. «Про освіту» Закон України [Електронний ресурс]. - Режим доступу: http://zakon3.rada.gov.ua/laws/show/2145-19

10. Сучасні концепції менеджменту : навч. посіб. / за ред. д-ра екон. наук, проф. Л. І. Федулової. - К. : Центр навч. літ., 2007. $-536 \mathrm{c}$.

11. Шульга Р.Р. Категорія «торгівля послугами»: сутність та проблеми застосування у господарському законодавстві України , Р.Р.Шульга [Електронний ресурс]. - Режим доступу: $\quad$ http://www.irbis-nbuv.gov.ua/cgibin/irbis_nbuv/cgiirbis_64.exe?C21COM=2\&I21DBN=UJRN $\&$ P21DBN=UJRN\&IMAGE_FILE_DOWNLOAD=1\&Image _file_name=PDF/FP_index.htm_2010_4_158.pdf

\section{REFERENCES}

1. Astakhova E. V. Personnel building of the Higher School of Ukraine: metamorphoses of development: monograph / EV Astakhova; Ukr. acad. [c. history of Ukraine]. - H.: LSA Publishing, 2006. - $188 \mathrm{p}$.

2. Batechko N.G. Modern composition of the development of human resources potential of higher education in Ukraine / N.G. Batechko [Electronic resource]. - Access mode

http://www.irbis-nbuv.gov.ua/cgibin/irbis_nbuv/cgiirbis_64.exe?C21COM=2\&I21DBN=UJRN $\&$ P21DBN=UJRN\&IMAGE_FILE_DOWNLOAD=1\&Image _file_name=PDF/pptp_2013_3_3.pdf

3. Encyclopedia of Education / APS of Ukraine; [heads Ed. V.G. Kremeny]. - K.: Yurincom Inter, 2008. - 1040 p.

4. Korotkov EM Management of the quality of education: Textbook. manual for high schools / EM Korotkov. - M.: Academ. The project; The World, 2006. - 320 p.

5. Lunyachek V.E. Preparation of Masters of Public Administration for Quality Assurance: Theory and Practice: Monograph / V.E. Lunyachek. - Kh.: KhNU named after V. N. Karazin, 2011. - 372 p.

6. Monitoring the quality of education: world achievements and Ukrainian perspectives / for the constituencies. Ed. O. I. Lokshina. - K.: I.K., 2004. - 128 p.

7. "On Higher Education" Law of Ukraine [Electronic resource]. Access mode: http://zakon5.rada.gov.ua/laws/show/ru/1556-18

8. On Approval of the National Framework of Qualifications of Ukraine: Decree of the Cabinet of Ministers of Ukraine dated November 23. 2011 № 1341 [Electronic resource]. - Access 
mode: http://zakon2.rada.gov.ua/laws/show/ 1341-2011$\% \mathrm{D} 0 \% \mathrm{BF}$.

9. "On Education" Law of Ukraine [Electronic resource]. - Access mode: http://zakon3.rada.gov.ua/laws/show/2145-19

10. Contemporary Management Concepts: Teach. manual / ed. Dr. Econ. Sciences, prof. L. I. Fedulova. - K.: Center for teaching. $2007,536 \mathrm{p}$
11. Shulga R.R. Category «Trade in services»: the essence and problems of application in the economic legislation of Ukraine, R.R.Shulga [Electronic resource]. - Access mode: http://www.irbisnbuv.gov.ua/cgibin/irbis_nbuv/cgiirbis_64.exe $? \mathrm{C} 21 \mathrm{COM}=2 \& \mathrm{I} 21 \mathrm{DBN}=\mathrm{UJRN} \& \mathrm{P} 21 \mathrm{DBN}=\mathrm{UJRN} \& \mathrm{IMAGE}$

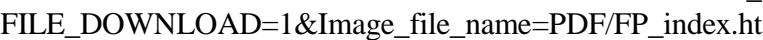
m_2010_4_158.pdf

Ensuring the quality of higher education in Ukraine: the challenges of today

\section{A. V. Kuruch}

Abstract. The problem of quality assurance in higher education institutions of Ukraine in the context of the requirements of the Laws of Ukraine "On Education" and "On Higher Education" is considered in this paper. The material is provided in accordance with the characteristics of the groups: the quality of the educational achievement potential, the quality of the process of formation of professionalism and the quality of the result of education. The work proved the need to address the issue of providing high-quality educational services in higher educational institutions of Ukraine from the point of view of the system approach by creating a certain "road map" from both the state and the higher educational establishments itself. Particular emphasis is placed on the problems of improving the motivation of participants in the educational process in universities, providing individual development trajectories for each student, and further improving the legal and regulatory framework of higher education. Considerable attention is also paid to the use of information technology in the learning process, especially the need to take into account the possibilities of modern gadgets, etc. The issue of ensuring the provision of quality educational services is directly linked with the implementation of the competency paradigm in education.

Keywords: higher education institution, competence approach, professional training, faculty members, quality of education, quality of educational process.

\section{Обеспечение качества образования в Украине: вызов современности}

\section{А. В. Куруч}

Аннотация. В работе рассматриваются проблемные вопросы обеспечения качества образования в высших учебных заведениях Украины в контексте требований Законов Украины «Об образовании» и «О высшем образовании». Материал предоставлен согласно группами характеристик: качество потенциала достижения цели образования, качество процесса формирования профессионализма и качество результата образования. В работе доказана необходимость решения вопроса предоставления качественных образовательных услуг в вузах Украины с позиций системного подхода путем создания определенной «дорожной карты» как со стороны государства, так и самих высших учебных заведений. Особый акцент сделан на проблемах улучшения мотивации участников учебного процесса в вузе, обеспечении индивидуальных траекторий развития для каждого студента, дальнейшем совершенствовании нормативно-правовой базы высшего образования. Значительное внимание уделено также использованию информационных технологий в учебном процессе, особенно необходимости учета возможностей современных гаджетов и тому подобное. Вопрос обеспечения предоставления качественных образовательных услуг непосредственно связываются с реализацией компетентностной парадигмы в обучении.

Ключевые слова: высшее учебное заведение, компетентностный подход, профессиональная подготовка, профессорскопреподавательский состав, качество образования, качество образовательного процесса. 


\title{
Критичне осмислення визначення компетентності в правових актах України про освіту
}

\author{
Г. М. Мицик \\ аспірант Запорізького національного університету
}

Paper received 01.06.18; Accepted for publication 09.06.18.

\section{https://doi.org/10.31174/SEND-PP2018-170VI70-07}

\begin{abstract}
Анотація: У статті здійснено порівняльно-правовий аналіз значення терміна «компетентність», виокремлено загальні та відмінні його риси. Висловлено припущення щодо невідповідності в окремих випадках норм-дефініцій компетентності меті, яка переслідується спеціальним законом про освіту. Робляться висновки про необхідність їх уточнення з урахуванням зазначеного.

Ключові слова: компетентність, результати навчання, особисті якості, якість дій, здатність, професійна діяльність, подальша навчальна діяльність.
\end{abstract}

Вступ. В наукових колах, не дивлячись на досить поширене застосування поняття компетентності, і до теперішнього часу немає єдності стосовно його визначення. Різноманітність джерел дозволяє розглянути компетентність в площині лексичного, наукового та нормативного тлумачення. Вважалося б, що надання компетентності законодавчого визначення мало б зняти всі сумніви щодо іiі розуміння. Все ж питання, які вимагають відповіді, залишаються і вони зумовлюють більш детально приділити цьому уваги.

Короткий аналіз публікацій за темою дослідження. Поняття компетентності було предметом наукових досліджень багатьох науковців. Власні погляди щодо його визначення виклали в своїх працях Н. П. Волкова, М. С. Головань, О. І. Гура, І. М. Ільківська, Г. К. Кенбаєва, Н. В. Кузьміна, О. І. Пометун, П. М. Решетник, Л. Ю. Стєпашкіна, А. В. Хуторський, М. Г. Янова та ін. Тим не менш, незважаючи на таку увагу, слід зазначити, що у вітчизняній педагогіці відсутні роботи, в яких надали б відповідну оцінку правовому визначенню поняття компетентності. Як правило відбувається констатування наявності такого поняття без відповідного його аналізу.

Виділення невирішених раніше частин загальної проблеми. Важливість критичного осмислення визначення компетентності в правових актах України про освіту пояснюється багатьма факторами, ключовими 3 яких можуть вважатись наступні: по-перше, будь-яке дослідження завжди виграє, коли у його рамках дається чітке визначення понять, що в ньому використовуються; по-друге, $є$ можливість провести розмежування між схожими за змістом поняттями; по-третє, виникає можливість проаналізувати переваги, недоліки того чи іншого запропонованого поняття та запропонувати авторське бачення його дефініції. У зв'язку із цим не втрачає своєї актуальності питання щодо удосконалення використовуваного в правових актах про освіту понятійного апарату, переосмислення законодавчо визначеного поняття компетентності.

Мета - дослідити визначення компетентності в правових актах України про освіту на предмет його узгодженості з метою, яка переслідується спеціальним законом про освіту.

Матеріали та методи. Основоположним методом, що використовувався при дослідженні, став загальнонауковий діалектичний метод пізнання як засіб вивчення соціально-правових явищ у їх суперечностях, розвитку та змінах, що дає можливість досліджувати проблеми визначення компетентності в правових актах України про освіту у взаємозв'язку з іншими соціальними яви- щами. Формально-логічний метод застосовувався для з'ясування правової сутності та значення компетентності. Розширенню бачення шляхів розв'язання проблеми через аналіз значення терміна «компетентність», виокремленню загальних та відмінних його рис на рівні окремих нормативно-правових актів України про освіту сприяв порівняльно-правовий метод. Основні висновки дослідження, пропозиції щодо уточнення значення терміну «компетентність» обгрунтовано за допомогою методу системного аналізу національного законодавства про освіту. Нормативну основу дослідження склали закони України, нормативно-правові акти Президента України, нормативні акти Міністерства освіти і науки України, які регламентують подібні питання.

Результати та їх обговорення. Ключовим завданням освіти у XXI столітті є розвиток мислення, орієнтованого на майбутнє. Сучасний ринок праці вимагає від випускника не лише глибоких теоретичних знань, а і здатності самостійно застосовувати їх у нестандартних, постійно змінюваних життєвих ситуаціях, переходу від суспільства знань до суспільства життєво компетентних громадян [4]. В Стандартах вищої освіти (далі - Стандарт) педагогічних вищих навчальних закладів, які, в недалекому минулому, узагальнювали вимоги до змісту вищої освіти 3 напряму підготовки 6.010105 Корекційна освіта (за нозологіями), освітньо-кваліфікаційного рівня бакалавр компетентність було визначено як «інтегровану характеристику якостей особистості, результат підготовки випускника вищого навчального закладу (далі ВН3) для виконання діяльності в певних професійних та соціально-особистісних предметних областях (компетенціях), який визначається необхідним обсягом і рівнем знань та досвіду у певному виді діяльності». При їх розробці використовувалися терміни та визначення, що були подані у Комплексі нормативних документів для розроблення складових системи галузевих стандартів вищої освіти (далі - Комплекс) [6].

Запропоноване визначення мало досить звужений зміст. Результат підготовки випускника, який уособлювався з компетентністю, обмежувався лише знаннями та досвідом. Їх необхідний обсяг і рівень, як вважалося, i мав засвідчувати здатність особи успішно здійснювати діяльність в певних професійних та соціальноособистісних предметних областях. Зауважимо, що в Комплексі свого визначення отримали й такі слова як уміння та навички, проте, в запропонованому понятті компетентності вони не знайшли свого втілення. $€$ сумніви і щодо доцільності використання в його тексті такої складової як досвід. Його набуття - наслідок досить тривалого знаходження особи в професії. Він $є$ показни- 
ком активного практичного пізнання, яке відбувається вже по завершенню навчання. Тому його складно розглядати в якості результату підготовки випускника ВНЗ. Певним чином спростовує це і Комплекс. Аналіз запропонованого ним визначення терміну «первинна посада» засвідчує, що це посада, яка не потребує від випускників навчального закладу попереднього досвіду професійної практичної діяльності. Проте нема підстав сприймати такі неузгодженості в термінології досить критично. Комплекс став чи не першим документом, який мав забезпечити розробку складових системи галузевих стандартів вищої освіти на єдиній методологічній основі 3 урахуванням рекомендацій Болонської групи щодо застосування компетентнісного підходу до проектування стандартів освіти. В ньому було надано визначення термінам, які до цього офіційно в сфері освіти не використовувалися але з часом стали для неї визначальними. Неоднозначність в їх сприйнятті лише сприяла подальшим науковим розробкам у цьому напрямку, як, зокрема, і у з'ясовані природи співвідношення між собою компетентності та компетенції. В Комплексі остання $є$ чи не найбільш вживаною категорією. Застосування компетентнісного підходу до розробки галузевих стандартів вищої освіти повинно було привести до формування нової системи діагностичних засобів із переходом від оцінки знань до оцінки компетенцій та визначення рівня компетентності в цілому. Передбачалося, що саме компетенціями випускника мала визначатися якість його підготовки вимогам галузевого стандарту вищої освіти. Запропоноване в Комплексі поняття компетенції включає знання й розуміння (теоретичне знання академічної області, здатність знати й розуміти), знання як діяти (практичне й оперативне застосування знань до конкретних ситуацій), знання як бути (цінності як невід'ємна частина способу сприйняття й життя з іншими в соціальному контексті). Це предметна область, у якій індивід добре обізнаний і в якій він проявляє готовність до виконання діяльності [6]. Тоді як компетентність асоціюється з результатом підготовки. Її єдина і, мабуть, головна властивість зведена до підтвердження здатності особи виконувати діяльність в певних професійних та соціально-особистісних предметних областях. Проте невизначеність у їх співвідношенні між собою залишалася. Певної суперечливості додавав і Комплекс, задекларувавши, що домінуючим в освіті стає формування особистісних характеристик майбутнього фахівця у вигляді системи компетенцій, підкресливши при цьому узагальнений, інтегральний характер поняття «компетенція» стосовно понять «знання», «уміння», «навички».

На сучасному етапі не можна не відзначити певного переосмислення самої сутності компетентнісного підходу. Основним напрямком розвитку систем освіти визначається формування цінностей і необхідних для успішної самореалізації компетентностей. Використання, досить вживаного в недалекому минулому в освітній сфері терміну «компетенція», зведено нанівець.

На відміну від Комплексу, в Законі України «Про вищу освіту» (далі - Закон) в редакції від 01.07.2014 р. термін «компетентність» отримав більш ширше трактування і вживається в такому значенні: «це динамічна комбінація знань, вмінь і практичних навичок, способів мислення, професійних, світоглядних і громадянських якостей, морально-етичних цінностей, яка визначає здатність особи успішно здійснювати професійну та подальшу навчальну діяльність і є результатом навчання на певному рівні вищої освіти» [2]. Проте вважаємо, що таке його визначення не зовсім узгоджується 3 метою, означеною в преамбулі Закону. Відзначимо, що такою $є$ підготовка конкурентоспроможного людського капіталу для високотехнологічного та інноваційного розвитку країни, самореалізація особистості, забезпечення потреб суспільства, ринку праці та держави у кваліфікованих фахівцях. Саме для цього Закон встановлює правові, організаційні, фінансові засади функціонування системи вищої освіти, створює умови для посилення співпраці державних органів і бізнесу з закладами вищої освіти на принципах автономії закладів вищої освіти, поєднання освіти 3 наукою та виробництвом. Зазначеним цілям відповідає й мета осіб, які навчаються у закладі вищої освіти, - це здобуття відповідного ступеня і кваліфікації. Зауважимо, вона ніяким чином не пов'язується з їх подальшою навчальною діяльністю, не зважаючи на те, що Законом це передбачено. Тому використання такого словосполучення в запропонованому визначенні, на наше переконання, є недоречним. Якщо ж студент і скористається в майбутньому такою можливістю, навчаючись на рівні вищому від попереднього, його мета в межах зазначено Закону залишиться незмінною. Насамперед це здобуття поглиблених знань, умінь, навичок, інших компетентностей за обраною спеціальністю, підвищення престижу й авторитету, утвердження свого становища в професії. Такому нашому припущенню знаходимо підтвердження в ст. 17 Закону України «Про освіту» від 05.09.2017 р., в якій зазначено, що метою вищої освіти $\epsilon$ здобуття особою високого рівня наукових та/або творчих мистецьких, професійних і загальних компетентностей, необхідних саме для діяльності за певною спеціальністю чи в певній галузі знань. Досить показовим в цьому сенсі є наказ Міністерства освіти і науки України (далі - МОН України) «Про затвердження кваліфікаційних характеристик професій (посад) педагогічних та науково-педагогічних працівників навчальних закладів від 01.06.13 р. № 665 [3], в якому під компетентністю пропонується розуміти якість дій працівника, що забезпечують адекватне та ефективне вирішення професійно важливих предметних завдань, що мають проблемний характер, а також готовність нести відповідальність за свої дії. В наведеному визначенні областю реалізації компетентності працівника визначена саме професійна діяльності. Іншою його особливістю $є$ те, що на відміну від наведеного в Законі «Про вищу освіту» визначення компетентності зазначене уособлює компетентність не 3 результатами навчання, а 3 діями конкретного працівника, яким, зокрема, може бути й педагогічний працівник особа, яка провадить навчальну, виховну, методичну, організаційну роботу та іншу педагогічну діяльність, передбачену трудовим договором у формальній та/або неформальній освіті. В такому розумінні компетентність відображає практичні можливості працівника в професії, а відтак і рівень їхньої діяльності, спрямований на виконання виробничих функцій відповідно до посади, яку обіймає.

Певним чином такому нашому припущенню знаходимо підтвердження і в запропонованому МОН України проекті Концепції розвитку педагогічної освіти, в якому складовою професійної кваліфікації педагогічного працівника визнається стандартизована сукупність здобутих особою компетентностей (результатів навчання), що дозволяють виконувати функції педагогічного працівника у формальній та неформальній освіті або здійсню- 
вати професійну педагогічну діяльність поза межами закладу освіти [1]. Тобто акцент знову ж таки зосереджено саме на професійній діяльності і аж ніяким чином на подальшій навчальній діяльності.

Безсумнівно, будь-яка професія змушує працівника професійно розвиватися та підвищувати свою кваліфікацію. Процес навчання та вдосконалення професійних компетентностей $є$ безперервним і триває впродовж усього періоду професійної діяльності фахівця. I відбувається він переважно на основі здобутої вищої освіти. Накопичення визнаних результатів навчання може бути підставою для присвоєння професійних (зокрема, часткових) та здобуття повних освітніх кваліфікацій. В цьому сенсі цілком виправдано подальшу навчальну діяльність, як одну з властивостей компетентності, розглядати саме в межах Закону України «Про освіту». I це знайшло своє відображення в ньому. В новій редакції Закону України «Про освіту» від 05.09.2017 р. компетентність визначено як динамічну комбінацію знань, умінь, навичок, способів мислення, поглядів, цінностей, інших особистих якостей, що визначає здатність особи успішно соціалізуватися, провадити професійну та/або подальшу навчальну діяльність [5]. У порівнянні з аналогічним поняттям, наведеним в Законі України «Про вищу освіту», відмінності незначні. Однак звертає на себе інше. В Законі України «Про освіту», який є загаль- ним по відношенню до Закону «Про вищу освіту», одним 3 принципів державної політики у сфері освіти $є$ сприяння навчанню впродовж життя, тоді як державна політика у сфері вищої освіти надає перевагу принципам наступності процесу здобуття вищої освіти, державної підтримки підготовки фахівців 3 вищою освітою для пріоритетних галузей економічної діяльності тощо. Наведе вказує на існування відмінностей у цілях, задекларованих в зазначених законах, і свідчить про необхідність відповідним чином це відтворити в нормі-дефініції компетентності.

Висновки. Наведене переконує нас в тому, що сенс терміну «компетентність», властивості, притаманні компетентності, мають визначатися виходячи 3 мети, яка переслідується спеціальним законом про освіту. Для одних такою є забезпечення потреб суспільства, ринку праці та держави у кваліфікованих фахівцях, робітниках, для інших - забезпечення соціальної адаптації та готовності продовжувати освіту; сприяння вільному розвитку людської особистості, оволодінню систематизованими знаннями, що стануть основою для подальшої освіти тощо. Законодавче визначення значення терміну «компетентність» в Законі України «Про вищу освіту» внесло певну ясність щодо іiі розуміння, однак і не позбавило недоліків. В будь-якому разі воно потребує уточнення.

\section{ЛITEРАТУРА}

1. Концепція розвитку педагогічної освіти (проект) [Е. ресурс] / Міністерство освіти і науки України. - Режим доступу : https: // mon.gov.ua/ ua/news/mon-proponuye-do-gromadskogoobgovorennya-proekt-koncepciyi-rozvitku -pedagogichnoyi-osviti

2. Про вищу освіту : закон України від 1 липня 2014 року № 1556-VII // Відомості Верховної Ради України. - 2014. - № 37 38. - Ст. 2004.

3. Про затвердження кваліфікаційних характеристик професій (посад) педагогічних та науково-педагогічних працівників навчальних закладів [Е. ресурс] : наказ Міністерства освіти і науки України від 01.06.13 р. № 665 / Міністерство освіти і науки України. - Режим доступу : http: // edu-mns.org.ua/

ukr/nmc/library/?id= 398

4. Про Національну стратегію розвитку освіти в Україні на період до 2021 року [Е. ресурс] : указ Президента України від 25.06.2013 p. № 344/2013 / Президент України. - Режим доступу : http: // zakon5.rada.gov.ua/laws/ show/344/2013

5. Про освіту : закон України від 5 вересня 2017 року № 2145-VIII //Відомості Верховної Ради України. -2017.-№ 38-39.-Ст. 380.

6. Щодо нормативно-методичного забезпечення розроблення галузевих стандартів вищої освіти [Е. ресурс] : лист Міністерства освіти і науки України від 31.07.2008 № 1/9-484 / Міністерство освіти і науки України. - Режим доступу : http: // consultant.parus.ua/?doc $=0655 \mathrm{CD} 926 \mathrm{~B}$

\section{REFERENCES}

1. Concept of development of pedagogical education (project) [E. resource] / Ministry of Education and Science of Ukraine. - Mode of access: https: // mon.gov.ua/ua/news/mon-proponuye-dogromadskogo-obgovorennya-proekt-koncepciyi-rozvitkupedagogichnoyi-osviti

2. About Higher Education: Law of Ukraine dated July 1, 2014 № 1556-VII // Bulletin of the Verkhovna Rada of Ukraine. - 2014 No. 37-38. - Art. 2004

3. On approval of qualification characteristics of professions (positions) of pedagogical and scientific-pedagogical workers of educational institutions [E. resource] : the order of the Ministry of Education and Science of Ukraine dated 01.06.13 № 665 / Ministry of Education and Science of Ukraine. - Mode of access: http: // edu-mns.org.ua/ukr/nmc/library/?id=398
4. About the National Strategy for the Development of Education in Ukraine until 2021 [E. resource]: Decree of the President of Ukraine dated June 25, 2013 № 344/2013 / The President of Ukraine. - Mode of access: http: // zakon5.rada.gov.ua/laws/ show / $344 / 2013$

5. On Education: Law of Ukraine dated September 5, 2017 No. 2145VIII // Bulletin of the Verkhovna Rada of Ukraine. - 2017 - № 3839. - Art. 380.

6. Regarding normative and methodological support for the development of sectoral standards for higher education [E. resource]: letter from the Ministry of Education and Science of Ukraine dated July 31, 2008 No. 1 / 9-484 / Ministry of Education and Science of Ukraine. - Access mode: http: // consultant.parus. ua/?doc=0655CD926B

Critical understanding of the definition of competence in the legal acts of Ukraine on education

\section{A. M. Mytsyk}

Abstract. In the article comparative-legal analysis of the meaning of the term «competence» is made, the general and distinctive features of it are singled out. The assumptions about the discrepancy in certain cases of norms-definitions of competence to the purpose pursued by a special law on education are expressed. Conclusions are made on the need for their refinement, taking into account the above.

Keywords: competence, learning outcomes, personal qualities, quality of action, ability, professional activity, further educational activity.

\section{Критическое осмысление определения компетентности в правовых актах Украины об образовании}

\section{А. М. Мыцык}

Аннотация. В статье осуществлен сравнительно-правовой анализ значения термина «компетентность», выделены общие и отличительные его черты. Высказано предположение о несоответствии в отдельных случаях норм-дефиниций компетентности цели, преследуемой специальным законом об образовании. Делаются выводы о необходимости их уточнения с учетом указанного.

Ключевые слова: компетентность, результаты обучения, личностные качества, качество действия, способность, профессиональная деятельность, дальнейшая учебная деятельность. 


\title{
Redefining the system of higher education in Ukraine within the context of the internationalization process: practical rationale
}

\author{
I. V. Myhovych \\ State Institution Luhansk Taras Shevchenko National University, Starobilsk, Ukraine \\ Corresponding author. E-mail: irina.migovich@gmail.com
}

Paper received 19.05.18; Accepted for publication 27.05.18.

https://doi.org/10.31174/SEND-PP2018-170VI70-08

\begin{abstract}
The article is devoted to the investigation of the process of internationalization within the context of higher education. Internationalization is viewed as a reaction to the global transformation processes, as well as a unique possibility for Ukrainian higher education system to ensure its integrated transformation according to European and world trends. Based on the research on the theory of internationalization, international education, overseas recruitment and staff mobility, issues of quality and management in higher education a number of practical rationales for internationalization of higher education applicable within the context of Ukrainian higher education system have been outlined. Based on the rationales educational outcomes of internationalization in Ukrainian higher education have been substantiated.
\end{abstract}

Keywords: the process of internationalization, global higher education system, Ukrainian system of higher education, rationales for internationalization.

Introduction. One of the key features of the modern world is its extraordinary dynamism, the complexity and increasing interdependence of all the transformational processes that are currently taking place. There is an increased need to strengthen partnerships and coordinate actions at the national, regional and international levels in order to ensure the quality and well-being of higher education systems worldwide. As a response to this need for an integrated transformation of higher education (HE) the process of internationalization has come in view.

The emergence of internationalization is generally connected with the increased political, socio-economic, cultural and ideological homogeneity across countries based on increasing digitalization of the world, accelerating cross-border financial flows and integration of economic activity, accelerating migration, blurring of national boundaries in favor of free cross-border movement and increasing use of common currencies and languages across different nations. Thus, internationalization is the response not only to the needs of $\mathrm{HE}$, but also to the needs of international economic, social, political and cultural integration, which is growing in the face of globalization.

International cooperation is currently been considered as one of the main indicators of the definition of quality in the field of education and science and, at the same time, one of the main tools for its maintenance and enhancement. Therefore, almost all higher education institutions (HEIs) around the world are engaged in international activities and seek to expand them. Internationalization thus has ceased to be casual or specialized, and has become a more centralized, well-organized, and thoughtful component of institutional work [12, p. 45]. According to F. Maringe, over the years it has developed to become the focus of activities by leading HEIs of the world and regulatory authorities at the national and global levels [9]. At the same time in Ukrainian HE the process of internationalization remains to be quite marginal and fragmented involving mainly small-scale student and staff exchanges.

Brief review of publications on the topic. Internationalization of $\mathrm{HE}$ has been investigated by $\mathrm{N}$. Avshenyuk, N. Bidyuk, T. Desyatova, N. Zhuravskaya, I. Zadorozhna, T. Klyuchkovich, N. Lavritschenko, M.
Leschenko, A. Parinova, G. Rzhevska, A Sbravieva, J. Ainer, M. Bartell, L. K. Childress, J. L. Davies, J. Knight, M. van der Wende, W. de Winter, H. de Wit, D. Van Damme, J, Taylor, J. D. Toma, D. Walters \& T. Adams, L. Wilson.

The meaning of globalization and internationalization in HE has been analyzed by F. Maringe. N. Foskett has investigated the strategic challenges of internationalization within the context of global markets, national challenges and local strategies. J. Taylor has studied the management of internationalization in HE. Eva Egron-Polak has viewed the process of internationalization as a gateway to a new inclusive global HE space, while Berndt Waechter has looked at this process within the context of student mobility. The future of this process in AsiaPacific region has been outlined by A. Ruby. All the works mentioned above have presented different approaches to this process, outlined its history, impact on world affairs and other facets of human development and endeavor. However, the practical rationales of its implementation in Ukrainian higher education area have not yet been sufficiently investigated.

The goal. The purpose of the article is to investigate different aspects of the process of internationalization as a reaction to global transformation processes and a means for Ukrainian HE system to ensure its integrated transformation according to European and world HE standards, to offer an additional point of view on the epistemology of internationalization, as well as on practical reasons for the introduction of this process into the system of Ukrainian HE.

Materials and methods. The methodological and theoretical basis of the research is the scientific works on international education, quality and management in HE, growth of entrepreneurial education and the associated managerialism in HE, national and institutional strategies for incorporation of international education into existing curricula. The validity of the obtained results is confirmed using various generally accepted and specific methods: theoretical generalization, abstraction, dialectical analysis, comparison and systematization, system approach.

Results and discussion. It is generally acknowledged that the key factor for the emergence of the process of 
internationalization has been globalization that entails the opening up and coming together of business, trade and economic activities between nations, necessitating the need for greater homogenization of fundamental political, ideological, cultural and social aspects of life across different countries of the world. Such processes have been taking place for a long time, but have been accelerated and intensified in the past decades because of developments in technology, computers and the Internet. The impact these changes are having on universities is pro- found and, within universities, the key strategic responses to globalization have come to be known as internationalization. It is generally understood to mean the integration of an international or intercultural dimension into the tripartite mission of teaching, research and service functions of HE $[1-3 ; 6 ; 7 ; 11,13]$.

Table 1 provides a summary of definitions and perspectives of internationalization by some of the most influential writers in this field.

Table 1. Conceptualizations of internationalization in HE

\begin{tabular}{|c|c|c|}
\hline $\begin{array}{l}\text { View of Internationaliza- } \\
\text { tion }\end{array}$ & Definition / Perspective & Source \\
\hline \multirow[b]{2}{*}{$\begin{array}{l}\text { Integration of the internation- } \\
\text { al dimension }\end{array}$} & $\begin{array}{l}\text {... internationalization at the national, sector, and institutional levels is defined as } \\
\text { the process of integrating an international, intercultural, or global dimension into } \\
\text { the purpose, functions or delivery of postsecondary education. }\end{array}$ & $\begin{array}{l}\text { J. Knight, } \\
2004\end{array}$ \\
\hline & $\begin{array}{l}\text { The intentional process of integrating an international, intercultural or global } \\
\text { dimension into the purpose, functions and delivery of post-secondary education, } \\
\text { in order to enhance the quality of education and research for all students and } \\
\text { staff, and to make a meaningful contribution to society. }\end{array}$ & de V \\
\hline Enhancing the $q$ & $\begin{array}{l}\ldots \text { increasing focus on international e } \\
\text { global labor market, but equally raises }\end{array}$ & $\begin{array}{r}\operatorname{Van} \mathrm{D} \\
20 \\
\end{array}$ \\
\hline $\begin{array}{c}\text { Focus on internatic } \\
\text { tion }\end{array}$ & $\begin{array}{l}\text {... ranges from traditional study abroad programs, which allow students to learn } \\
\text { about other cultures, to providing access to HE in countries where local institu- } \\
\text { tions cannot meet the demand. Other activities stress upgrading the international } \\
\text { perspectives and skills of students, enhancing foreign language programs, and } \\
\text { providing cross-cultural understanding. }\end{array}$ & $\begin{array}{l}\text { Altbach and } \\
\text { Knight, } 2006\end{array}$ \\
\hline $\begin{array}{l}\text { Growth of enterprise, entre- } \\
\text { preneurialism and manageri- } \\
\text { alism in HE }\end{array}$ & $\begin{array}{l}\ldots \text { internationalization as crucial for universities to retain competitiveness } \\
\text { through university business models which underpin an entrepreneurial culture ... } \\
\text { universities as entirely business entities. }\end{array}$ & $\begin{array}{l}\text { Goddard, } \\
2006\end{array}$ \\
\hline $\begin{array}{r}\text { Overseas studer } \\
\text { and staff mol }\end{array}$ & $\begin{array}{l}\begin{array}{l}\ldots \text { flows of staff and students in both directions, strategic alliances, joint pro- } \\
\text { grammes with external institutions. }\end{array} \\
\end{array}$ & 08 \\
\hline $\begin{array}{l}\text { Partnership development in } \\
\text { HE }\end{array}$ & $\begin{array}{l}\ldots \text { a focus on the development of partnerships to reduce risk, increase competi- } \\
\text { tiveness, enhance image and broaden the knowledge base for research, enterprise } \\
\text { and education. }\end{array}$ & $\begin{array}{l}\text { Teichler, } \\
2004\end{array}$ \\
\hline
\end{tabular}

One might say that most universities operate primarily in their own national space and context, and are part of the educational system within their own country. Shaped in many ways by history and legislative / governmental acts and policies in relation to education, their key accountabilities lie within their own national boundaries. However, it is exactly the process of internationalization that is to become their gateway to a global HE system.

For Ukraine the requirements of globalization and European integration for a long time remained rather vague. This fact has influenced the processes of internationalization of HE that has never been viewed as a priority of the state educational policy. Within the implementation of Joint Declaration of the European Ministers of Education (the Bologna Declaration) provisions formal aspects related to the introduction of the system of credits and twolevel training in Ukrainian HE prevailed. However, while in European countries such implementation considered to be an instrument for ensuring large-scale student mobility, there has been no significant increase in academic mobility in Ukraine over the last decade. The requirements of globalization and eurointegration did not integrate properly into the national strategy for the development of Ukrainian HE. Although in the Law "On Higher Education" (2014) international integration of Ukrainian HE is one of the main principles state educational policy is based upon, the notions of international cooperation, international integration, internationalization have not been mentioned among the basic terms, and in the Law itself there is no mentioning of the term internationalization [8].

Insufficient attention to the issues of internationalization in Ukrainian HE system has turned into slow proceeding of the process, which is evident, if to have close look at the following data:

- the number of students taking part in mobility programs rates from 5,000 to 10,000 persons per year, which is $0,5-1,0 \%$ of the total amount of students of HEIs with the III - IV levels of accreditation (full-time study) and total amount of students of HEIs with the I - II levels of accreditation (full-time study). At the same time there is practically no participation of Ukrainian teachers and professors in mobility programs [10, p. $130-143]$.

- The percentage of involvement of researchers and university teachers in international cooperation is quite low - proportion of those who have studied or worked abroad is small and number of holders of foreign academic degrees is negligible. Ukraine continues to be the country mainly exporting staff with higher scientific qualifications abroad [14, p. 88].

- Professorial staff of Ukrainian HEIs is insufficiently represented on the world scholar arena.

- HEIs of Ukraine are practically not represented, or they have low institutional ranking, in the leading international HE rating systems.

- Low activity of national HEIs in establishing partnerships with HEIs and research institutions abroad. As the 
result, the issue of cooperation of Ukrainian HEIs with foreign leading HEIs has a non-systematic character.

Today, just as well as 25 years ago, internationalization is not perceived as an urgent need that might foster the development of Ukrainian HE. The present article is aimed to give an answer to the question "why internationalize?" in a realistic and sufficiently pragmatic way. The idea of becoming competitive on the world educational market is extremely ambitious for Ukrainian $\mathrm{HE}$ - following many researchers in the field it is perceived as a longterm challenge. At the same time the task of improving quality of Ukrainian $\mathrm{HE}$ in accordance with world and European standards through the elaboration and implementation of new international educational programs and integration of international elements and educational standards looks more realistic and urgent. As the result, the article supports the following view on the problem Ukrainian HE system should integrate global and regional dimensions into its national context with the aim to harmonize national, global, regional requirements and conditions. To fulfill this task the following practical rationales have been outlined:

1. Political rationale is connected with the need to acquire, preserve and strengthen the independence and sovereignty of the nation / state and their role in the international arena. For HEIs political stimulus finds its manifestation in the idea to strengthen autonomy of state and enhance its status on the international arena. This dimension might as well be implemented through internationalization, international cooperation and partnership.

2. Economic rationale relates to the benefits that internationalization might bring to Ukrainian state economy and HEIs. It becomes of particular importance in the context of the development of knowledge economy and strengthening of the need to diversify the sources of financing for Ukrainian HEIs. This process is putting forward such objectives for Ukrainian HEIs: export of educational and research services, enrollment of foreign students. In this context the process of internationalization promotes possibility to receive grants for teachers, students, and HEIs themselves through joint granting schemes and development of strategic partnerships.

3. Academic rationale provides possibility to enhance the quality of Ukrainian HE by means of internationalization, which might be achieved by: internationalization of educational programs and courses; stimulation and organizational support for foreign internships of teachers, students, researchers; organization and participation of teachers, students and researchers in international scientific conferences; stimulation and organizational support of scientific publications in international journals and their representation in international science-computer databases; organizational support for carrying out joint scientific researches and educational and research projects with foreign researchers; development of international partnership between HEIs and between scientific communities; creation of international educational alliances. These activities can serve as a pragmatic goal for increasing international competitiveness of Ukrainian HEIs and their international reputation.

4. Cultural rationale is related to the expansion of opportunities for intercultural dialogue, cultural cooperation and partnership, education in the spirit of peace, for- mation of tolerance, etc. Here the study of a foreign language, first of all, English as a language of international communication and academic cooperation, becomes of great importance. But equally important is the ability to best position the traditions, culture and language of their own country. Social justification is related to the fact that students and researchers while in the international environment become less provincial, more open to the perception of the other, more tolerant and able to find understanding that can contribute to the improvement of social climate both in society and in the world.

Taking as the basis for the research the works by $\mathrm{J}$. Knight, to these four rationales the fifth - nationally relevant one - has been added. It means human resource development, strategic alliances for Ukrainian HEIs, state building and socio-cultural development, mutual understanding among different nations; at the institutional level - international branding and profiling, raising the quality of Ukrainian education in line with international revenuegenerating standards, developing strategic alliances and knowledge production [7, p. 25].

Thus, the system of HE in Ukraine can be redefined within the context of the internationalization process be means of the following: deepening, expanding and diversifying contacts with national, regional and global partners; better training of students as national and global citizens and productive members of society; expansion of students' access to educational programs and international mobility schemes; expanding the opportunities for faculty members and researchers to participate in international research activities, in international academic networks, to conduct research on burning international issues, and to use the experience and perspectives of scientists from many parts of the world; increasing institutional efficiency through the enrichment of international experience and partnership; improving of institutional policy, management, service functions through the exchange of experience across national borders; promoting the development of Ukraine at the expense of new financial revenues and multiplication of human, intellectual and innovative capital; contributing to global development and ensuring joint responsibility for it.

Conclusions. Universities have now become key players in the global economy, contributing significantly not only to the knowledge stock of the world, but also to the financial economy of their countries. Different universities will be expected to respond in different ways to globalization trends as much as they are also expected to have different conceptualizations of what it means to internationalize the roles of teaching, research, quality insurance and management. However, a review of the research works on the topic of internationalization in HE suggests that many universities have adopted a two-pronged approach to the internationalization process, encompassing home-based (internationalization at home) and overseasbased (internationalization abroad) activities.

Overall, the system of Ukrainian HE can be redefined within the context of the internationalization process within the five distinct sets of activities (based on the five practical rationales for internationalization outlined above): international student recruitment; student and staff mobility programmes; collaborative teaching programmes (joint degrees), overseas campuses and distance 
learning programmes; collaborative research and enterprise programmes; and curriculum reform programmes. Internationalization for Ukrainian HE system is of significant importance because of the following - people of today live and work in an increasingly interconnected globalized world as professionals, citizens and biological beings, they face a range of situations - challenges and opportunities - that require domestic HE systems and institutions to deliver something more apart from traditional education issues. In case internationalization pro- cess becomes more integrated into Ukrainian HE, the outcomes might be: appreciation and leverage of a multitude of international perspectives; ability to operate appropriately and effectively in an array of contexts, to make sense of world complexity. Thus, internationalization is not a goal itself. It means investment (of money and staff) which in the long run might improve some of the core tasks of Ukrainian HEIs - teaching, research, social engagement, efficiency, effectiveness, quality.

\section{REFERENCES}

1. Altbach P. G. The Internationalization of Higher Education: Motivations and Realities / P. G. Altbach, J. Knight. - Studies in International Education, 2006. - V. 1. - P. 290-305.

2. Beelen J. Redefining Internationalization at Home. - J. Beelen, E. Jones // The European Higher Education Area: Between Critical Reflections and Future Policies, 2015. Springer International. - P. 326.

3. Damme D. Van. Quality Issues in the Internationalization of Higher Education. - Higher Education, 2001. - Vol. 41. - P. $415-441$.

4. Fielden J. Lite Practice of Internationalization: Managing International Activities in UK Universities. - UK Higher Education International Unit, 2008. - P. 67.

5. Goddard S. E. Uncommon Ground: Indivisible Territory and the Politics of Legitimacy. - International Organization, 2006. - Vol. 60. - P. $35-68$.

6. Knight J. Internationalization Re-Modelled: Definition, Approaches, and Rationales. - Journal of Studies in International Education, 2004. - No. 8, (1). - P. 5 - 31.

7. Knight J. Higher Education in Turmoil. The Changing World of Internationalization. - Rotterdam, the Netherlands : Sense Publishers, 2008. - P. 25.

8. Law of Ukraine On Higher Education. - Electronic Access : http://bctdatu.zp.ua/zakon-pro-vishhu-osvitu.

9. Maringe F. Globalization and Internationalization of HE: An International Survey / F. Maringe, J. Foskett. - School of Education : University of Southampton Press, 2009. - P. 136.

10. Monitoring of the Integration of Ukrainian Higher Education System into European Higher Education and Research Area: Analytical Report / Ed. T.V. Finikov, O. I. Sharov. - K. : Tacson, 2014. - 144 p. - P. $130-143$.

11. Teichler U. The Changing Debate on Internationalization of Higher Education. - Higher Education, 2004. - Vol 48. - P. 5 $-26$.

12. Trends in Global Higher Education: Tracking an Academic Revolution / Ph. G. Altbach, L. Reisberg, L. E. Rumbley. United Nations Educational, Scientific and Cultural Organization, 2009. - P. 45.

13. Wit K. de. The Consequences of European Integration for Higher Education. - Higher Education Policy, 2003. - No. 16 (2). - P. $101-178$.

14. Zhyliayev I. B. Higher Education in Ukraine: State and Problems / I. B. Zhyliayev, V. V. Kovtunets, M. V. Syomkin. - K. : Institute of Higher Education of the National Academy of Pedagogical Sciences of Ukraine, 2015. - P. 88.

Переопрделение системы высшего образования в Украине в контексте процесса интернационализации: практическое обоснование

И. В. Мигович

Аннотация. Статья посвящена исследованию процесса интернационализации в высшем образовании. Интернационализация рассматривается как реакция на глобальные процессы трансформации, а также как уникальная возможность для украинской системы высшего образования обеспечить интеграцию в соответствии с европейскими и мировыми тенденциями. На основе исследования теории интернационализации, международного образования, международного рекрутинга и мобильности персонала, вопросов качества и управления в высшем образовании изложен ряд практических обоснований интернационализации высшего образования, применимых в контексте украинской системы высшего образования. На их основе обозначены образовательные результаты интернационализации в украинском высшем образовании.

Ключевые слова: процесс интернационализачии, глобальная система высшего образования, украинская система высшего образования, обоснование интернационализащии. 


\title{
Критеріально-рівневе оцінювання розвитку музично-творчих здібностей дітей 6-7 років у позашкільних навчальних закладах
}

\author{
Л. Ніколаснко \\ Сумський державний педагогічний університет імені А. С. Макаренка, м. Суми, Україна \\ Paper received 11.06.18; Accepted for publication 18.06.18.
}

\section{https://doi.org/10.31174/SEND-PP2018-170VI70-09} Анотація. У статті розкрито важливість критеріально-рівневого оцінювання творчих здібностей дітей 6-7 років у музичній
діяльності. Визначено критерії та показники розвиненості музично-творчих здібностей дітей 6-7 років у позашкільних нав-
чальних закладах. Висвітлено рівні розвитку музично-творчих здібностей дітей 6-7 років з урахуванням компонентів особи-
стості, що визначають структуру музично-творчих здібностей. Доведено необхідність експериментального дослідження 3
метою підтвердження чи спростування розроблених критеріїв, показників та рівнів.

Ключові слова: критеріально-рівневе оцінювання, критерії, показники, рівні розвитку, музично-творчі здібності, діти 6-7 років, позашкільні навчальні заклади.

Вступ. Всебічний розвиток дитини є одним із стратегічних напрямів сучасної освіти, про важливість і актуальність якого свідчать державні документи. Відповідно до Закону України «Про освіту» метою освіти є всебічний розвиток людини як особистості та найвищої цінності суспільства, розвиток ії талантів, інтелектуальних, творчих і фізичних здібностей, формування цінностей і необхідних для успішної самореалізації компетентностей, виховання відповідальних громадян, які здатні до свідомого суспільного вибору та спрямування своєї діяльності на користь іншим людям, формування громадян, здатних до свідомого суспільного вибору, збагачення на цій основі інтелектуального, творчого, культурного потенціалу народу [1, c. 3]. Згідно з Концепцією Нової української школи метою діяльності сучасних освітніх закладів $є$ виховання освічених українців, всебічно розвинених, відповідальних громадян і патріотів, здатних до ризику та інновацій [7, с. 6].

Як свідчать нормативні документи, всебічний розвиток особистості є пріоритетним напрямом художньо-естетичного навчання та виховання. Необхідною складовою цієї діяльності є музичне мистецтво. Аналіз психолого-педагогічної, мистецтвознавчої літератури дозволяє стверджувати, що для ефективного розвитку музично-творчих здібностей важливим $є$ визначення критеріїв, показників і рівнів розвитку творчих здібностей у музичній діяльності.

Аналіз останніх досліджень. На сьогодні питання творчості, формування людини нового типу, здатної до активної, творчої діяльності, є актуальними та важливими. Адже перехід до ринкових відносин, культурне зростання країни вимагає формування та розвитку творчих кадрів, які можуть швидко реагувати на мінливі умови життя, приймати нестандартні, творчі рішення. На думку Н. Ветлугіної, значні можливості для творчого розвитку підростаючого покоління має музичне мистецтво [2, с. 84].

Категорії «музичні здібності» та «творчі здібності» $\epsilon$ предметом дослідження багатьох педагогів, психологів, музикознавців. Так, проблематика творчих здібностей різнобічно розкрита у роботах Д. Богоявленської, А. Маслоу, К. Роджерса, у працях вітчизняних вчених М. Лазарєва, В. Моляка, А. Матюшкіна, В. Роменця, Л. Рубінштейна, Г. Костюшка, В. М'ясищева.
У дослідженнях Н. Ветлугіної, Е. Костиної, М. Леонтовича, О. Лобової, С. Науменко, К. Орфа, С. Садовенко, К. Стеценко, О. Радинової розглянуто шляхи розвитку музичних здібностей.

Синтетичне поняття «музично-творчі здібності» зустрічаємо лише в окремих дослідженнях (I. Артем’єва, О. Горожанкіна, Г. Дідич, К. Стецюк, С. Стадник та ін.). Проаналізувавши ці джерела 3 проблеми музичних і творчих здібностей, можна зробити висновок про недостатню розробленість поняття «музично-творчі здібності», відсутність єдиної точки зору на їх природу, сутність і структуру, особливості розвитку. Отже, спостерігаємо інтерес до питання творчості у музичній діяльності. Водночас, констатуємо складність та відносність діагностики здібностей, зокрема, музично-творчих; недостатню розробленість критеріїв та показників розвитку музично-творчих здібностей дітей 6-7 років у позашкільних навчальних закладах.

Мета статті полягає у розробленні та обгрунтуванні критеріїв, показників та рівнів розвитку музичнотворчих здібностей дітей 6-7 років у позашкільних навчальних закладах.

Методи дослідження. У підготовці даного матеріалу використано такі теоретичні методи як: аналіз, синтез, конкретизація, порівняння, узагальнення.

Виклад основного матеріалу. Розвиток музичнотворчих здібностей є важливим та актуальним для формування різнобічної особистості. Вагомий внесок у розроблення цього питання внесли О. Горожанкіна, О. Коваль, К. Стеценко, С. Стадник, Ч. Гуань.

На думку української дослідниці О. Горожанкіної, критеріями розвиненості музично-творчих здібностей $\epsilon$ сформованість загального інтелекту особистості, музичного мислення, здатність до емоційного реагування на музику, здібність до інтерпретації та імпровізації при мінімумі репродуктивної і максимумі продуктивної діяльності [5, с. 107].

С. Стадник критеріями розвитку музично-творчих здібностей вважає інтерес до музичного мистецтва, оригінальну реалізацію в ідеалістичному (ідеї, образи, теми, зміст і т. д.), теоретично-методологічному (символіка, і структура оперативних одиниць і величин, простеження закономірностей та відхилень у їхньому взаємозв'язку, фіксація цих процесів, способи фіксаціï), а також прикладному (створення цілісної музич- 
ної одиниці - твору чи новітнього виконавського вираження готового твору) аспектах музичної діяльності [8].

Науковець О. Коваль обгрунтовує такі критерії визначення рівня розвитку музичних здібностей молодших школярів:

- емоційний і пластичний відгук на музику;

- вияв слухової уваги;

- здатність виразно й емоційно виконувати музику;

- наявність улюблених творів, вибірковість музичних інтересів;

- інтерес до різних видів музичної діяльності: сприймання, виконання, творчості;

- уміння розуміти музику й насолоджуватися нею;

- усвідомлення зв'язків музики з життям;

- оригінальність суджень про музику;

- уміння аналізувати й інтерпретувати твір;

- потяг до музичної творчості;

- вияв ціннісного ставлення до музичних творів [4, c.11].

Цікавими є погляди С. Садовенко. Дослідниця виокремлює такі критерії сформованості музичних здібностей у дітей дошкільного віку:

- рівень емоційного інтересу дітей до музичної діяльності (наявність емоційного відгуку, відчуття ладового забарвлення, характер відповідних образних уявлень, асоціацій);

- ступінь сформованості елементарних вокальнослухових навичок і уявлень (адекватність реакції на зміну мелодії, чистота інтонування, розвиненість тембрового та динамічного слуху, наявність розпізнавальної та відтворюючої пам'яті);

- ступінь сформованості ритмічно-мовно-рухових умінь (відчуття музичного темпу та пауз, елементарна обізнаність у засобах музичної виразності, здатність відтворити у рухах метроритм твору, відповідність рухів характеру, образу, скоординованість зі співом та грою на дитячих музичних інструментах);

- міра здатності дітей до музично-творчої діяльності (бажання фантазувати та творчо самовиражатися, наявність творчих проявів у різних видах діяльності, міра прояву акторських здібностей у драматизації, розуміння ролі засобів музичної виразності у створенні художнього образу) [6, с. 105].

Сучасний дослідник Ч. Гуань акцентує увагу на творчій активності на заняттях музики та пропонує наступні критерії рівня іiі сформованості:

- критерієм сформованості мотиваційного компоненту визначено міру прояву інтересу до музичної творчості 3 показниками: прагнення пізнати сутність явищ в музиці; бажання внести свій внесок у процес творчості, реалізувати себе, досягти успіху та задоволення у творчій музичній діяльності;

- до критеріїв сформованості змістовно-діяльнісного компоненту віднесено: міру емоційної чутливості учнів на твори музичного мистецтва 3 показниками: уміння порівнювати, аналізувати, описувати музичні явища i процеси та ступінь розвитку художньообразної уяви з показниками: уміння фантазувати, моделювати, уявляти, оперувати різними образами і наочними уявленнями;

- критеріями оцінно-рефлексивного компоненту визначено ступінь розвитку самостійності у музично- пошуковій діяльності з показниками: наявність свідомої мотивованості у виборі дій, яскраво виражених прагнень до самостійного здійснювання музичнопошукової діяльності, внутрішнього підйому і енергії та міри спрямованості на власну творчу діяльність 3 показниками: вибір бажаного типу діяльності; захопленість творчим процесом, його продуктивністю; здатність до аналізу результату творчої діяльності [3, с. 128].

Таким чином, питання розвитку музично-творчих здібностей висвітлено у науково-методичній, психолого-педагогічній, мистецтвознавчій літератури. Проте iii аналіз дозволив констатувати відсутність єдиних критеріїв та показників щодо розвиненості музичнотворчих здібностей дітей. На основі науковотеоретичного аналізу нами було обгрунтовано критерії оцінювання розвитку музично-творчих здібностей дітей 6-7 років у позашкільних навчальних закладах, а саме:

- мотиваційно-творчий;

- емоційно-образний;

- вокально-творчий (здатність до вокальної імпровізаціiі);

- пластично-ритмічний (здатність до пластичноритмічної імпровізації);

- інструментально-творчий (здатність до інструментальної імпровізації).

Надамо коротку характеристику кожному вищезазначеному критерію.

1. Мотиваційно-творчий критерій виявляється в інтересі до музично-творчої діяльності, бажанні виконувати творчі завдання на заняттях музики, активно висловлюватися щодо отриманих вражень від музичного твору.

2. Емоційно-образний критерій - наявність музичнотворчих уявлень, емоційного відгуку на музику, образних асоціацій, здатність образно сприймати й переживати музичний твір,розвиток музично-творчого мислення.

3. Вокально-творчий критерій - здатність створити мелодію на заданий текст або відповідь на музичну фразу, імпровізувати у різному характері та жанрі, емоційність, виразність, артистизм у виконанні вокальних творів.

4. Пластично-ритмічний критерій виявляється в здатності до пластичної та ритмічної імпровізації, спроможність створювати оригінальні рухи, відчувати ритм музики та відтворювати його у рухливій діяльності

5. Інструментально-творчий критерій - здатність до інструментальної імпровізації, вміння створити ритмічний акомпанемент, музичний супровід на дитячих музичних інструментах, нові ритмічні поєднання.

Відповідно до вищезазначених критеріїв розроблено показники розвитку музично-творчих здібностей:

- показником розвитку мотиваційно-творчого компоненту є міра зацікавленості процесом творчості, характер ставлення до музично-творчої діяльності, готовність виконувати музично-творчі завдання, бажання висловлювати враженні від музики, прагнення досягти гарного результату.

- показником розвитку емоційно-образного компоненту стала наявність образних асоціацій, якість пе- 
реживання музики, емоційність, виразність, артистизм у виконанні вокальних, ритмічних, пластичних творів, емоційний відгук на музику, розвиненість емоцій;

- показником розвитку вокально-творчого компоненту визначено міра емоційності, артистизму під час виконання вокальних творів, якість та різноманітність виконання вокально-творчих завдань, здатність відчувати настрій, динаміку, темп музики та відтворювати їх голосом;

- до показників розвитку пластично-ритмічного компоненту віднесено якість рухів (оригінальність, різноплановість); міру узгодженості рухів із темпом, динамікою, штрихами, характером твору, готовність змінити їх із зміною у звучанні; координацію між рухами та співом; здатність відчувати ритм музики та відтворювати його у рухливій діяльності;

- критерієм розвитку інструментально-творчого компоненту є міра злагодженості рухів під час гри на дитячих музичних інструментах, різноманітність варіантів рішення музично-ритмічних завдань; здатність відтворити ритмічний рисунок на слух, уміння створити власну композицію на дитячих музичних інструментах.

Таблиця 1. Характеристики рівнів розвитку музично-творчих здібностей дітей 6-7 років у позашкільних навчальних закладах

\begin{tabular}{|l|l|l|l|}
\hline $\begin{array}{l}\text { № } \\
\mathbf{n} / \mathbf{I}\end{array}$ & Рівні & Бали & Показники \\
\hline 1 & $\begin{array}{l}\text { Низький (репро- } \\
\text { дуктивний) }\end{array}$ & $1-4$ & $\begin{array}{l}\text { Відсутність або слабкий інтерес до музично-творчої діяльності, здатність висловлювати власні } \\
\text { враження лише за допомогою педагога, неохоче виконання творчих завдань, малопродуктивна } \\
\text { уява, слаборозвинений емоційний відгук на музику. }\end{array}$ \\
\hline 2 & $\begin{array}{l}\text { Середній (проду- } \\
\text { ктивний) }\end{array}$ & $\begin{array}{l}\text { Активність в окремих видах діяльності, зацікавленість музично-творчої діяльністю, але 3 частим } \\
\text { відволіканням, відносно самостійна проте більш одноманітна, музично-творча діяльність. }\end{array}$ \\
\hline 3 & $\begin{array}{l}\text { Високий (твор- } \\
\text { чий) }\end{array}$ & $8-10$ & $\begin{array}{l}\text { Стійкий інтерес до музично-творчої діяльності, ії різноманітність, оригінальність мислення, за- } \\
\text { цікавленість під час виконання творчих завдань, розвинена асоціативно-образна уява, захопле- } \\
\text { ність процесом творчості. Координація між слухом, голосом, рухами, їх узгодженість із характе- } \\
\text { ром та образом. }\end{array}$ \\
\hline
\end{tabular}

Якісний аналіз різних підходів дозволив нам узагальнити рівні розвитку музично-творчих здібностей і визначити наступні: низький (репродуктивний), середній (продуктивний) та високий (креативний) (табл.1).

Низький (репродуктивний) рівень характеризується відсутністю або слабким інтересом до музичнотворчої діяльності, здатністю висловлювати власні враження лише за допомогою педагога, неохочим виконанням творчих завдань, малопродуктивною уявою, слаборозвиненим емоційним відгуком на музику. Для середнього (продуктивного) рівня характерні активність в окремих видах діяльності, зацікавленість музично-творчої діяльністю, але з частим відволіканням, відносно самостійна музично-творча діяльність, проте більш одноманітна. Високий (креативний) рівень: стійкий інтерес до музично-творчої діяльності, ïi різноманітність, оригінальність мислення, зацікавленість під час виконання творчих завдань, розвинена асоціативно-образна уява, захопленість процесом творчості. Надана характеристика цих рівнів, встановле- но приналежність вихованців до певного рівня згідно 3 розробленою нами десятибальною шкалою.

Висновки та перспективи подальших наукових розвідок. На основі визначених структурних компонентів музично-творчих здібностей дітей (мотиваційно-творчі, слухацько-творчі, вокально-творчі, пластично-творчі, інструментально-творчі) розроблено критерії та показники розвиненості музично-творчих здібностей дітей 6-7 років у позашкільних навчальних закладах. Зокрема: мотиваційно-творчий; емоційнообразний; вокально-творчий; пластично-ритмічний; інструментально-творчий. Кожен критерій має свої показники. Обгрунтовано такі рівні: низький (репродуктивний), середній (продуктивний) та високий (креативний). Перспективи подальших наукових розвідок вбачаємо у проведенні експериментального дослідження щодо розвитку та діагностики музичнотворчих здібностей дітей у позашкільних навчальних закладах.

\section{ЛІТЕРАТУРА}

1. Закон України «Про освіту» : чинне законодавство станом на 28 верес. 2017 року: (ОФІЦ. ТЕКСТ). - К.: ПАЛИВОДА А. В., 2017. - 128 с. - (Закони України).

2. Ветлугіна Н. Музичний розвиток дитини / Н. Ветлугіна. К. : «Музична Україна», 1978. - 255 с.

3. Гуань Ч. Методика формування творчої активності учнів початкової школи в процесі навчально-музичної діяльності : дис. .... канд. пед. наук : 13. 00.02 / Чжуань Гуань. K, 2017. $-229 \mathrm{c}$.

4. Коваль О. В. Формування музичних здібностей молодших школярів на уроках музики : автореф. дис. ... канд. пед. наук : 13.00 .02 / О. В. Коваль. - Київ, 2002. - 22 с.

5. Наукові записки. Серія «Психолого-педагогічні науки»
(Ніжинський державний університет імені Миколи Гоголя) / за заг. ред. проф. С. І. Коваленко. - Ніжин : НДУ ім. М. Гоголя, 2015. - № 2. - $173 \mathrm{c}$.

6. Садовенко С. М. Світ фольклору: Український дитячий музичний фольклор як засіб формування музичних здібностей дітей дошкільного віку. Науково-методичний посібник. - К.: КТ «Київська нотна фабрика», 2007. - 332 с.

7. Сидоренко В. Концепти Нової української школи / В. Сидоренко // Методист. - № 5 (травень). - С. 4-17.

8. Сутнісна характеристика музично-творчих здібностей особистості / Сергій Стадник [електронний ресурс]. Режим доступу: http://oldconf.neasmo.org.ua/node/836

\section{REFERENCES}

1. The Act of Ukraine «On education»: current legislation by the state on September 28, 2017: (GENERAL TEXT). - K.: PALYVODA A.V., 2017. - 128 p. ( Laws of Ukraine)

2. Vetluhina N. The musical child's development / N. Vetluhina.

\author{
- K.: «Musical Ukraine», 1978. - 255 p.
}

3. Huan C. Methodology of formation of the creative activity of primary school pupils in the process of the educational and musical activity : dis. ... PhD : 13. 00.02 / Chzhuan Huan. - 
K, 2017. $-229 \mathrm{p}$.

4. Koval O. V. The formation of the musical abilities of younger school children at the lessons of Music : dis. ... PhD : 13.00.02 / O. V. Koval. - Kyiv, 2002. - 22 p.

5. Scientific notes. Series «Psychological and pedagogical sciences» (Nizhyn state University named after Mykola Hohol) / after a general version of Prof. Y. I. Kovalenko. - Nizhyn: NSU named after M. Hohol, 2015. - № 2. - 173 p.

6. Sadovenko S.M. The world of folklore: Ukrainian child's folk- lore as means of formation of pre-school children's musical abilities. Scientific and Methodological Guidelines. - K.: KT «Kyiv musical factory», 2007. $-332 \mathrm{p}$.

7. Sydorenko V. Concepts of the New Ukrainian school / V. Sydorenko // Methodist. - № 5 (May). - P. 4-17.

8. Essence description of person's musical and creative abilities / Serhii Stadnyk [electronic resource]. - Access mode: http://oldconf.neasmo.org.ua/node/836

The criteria and level assessment of development of musical and creative abilities of 6 and 7 -year-old children in out-ofschool establishments

L. Nikolaienko

Abstract. The article reveals the importance of the criteria and level assessment of the development of children's musical and creative abilities in musical activity. The criteria and rates of the development of musical and creative abilities of 6 and 7-year-old children in out-of-school establishments are determined. The author reveals the levels of development of musical and creative abilities of 6 and 7-year-old children, taking into account the personality components that determine the structure of pupils' musical and creative abilities. The necessity of experimental research is in order to confirm or refute the developed criteria, rates and levels is proved.

Keywords: the criteria and level assessment, criteria, rates, the levels of development, musical and creative abilities, 6 and 7year-old children, out-of-school establishments

Критериально-уровневое оценивание развития музыкально-творческих способностей детей 6-7 лет во внешкольных учреждениях

\section{Л. Николаенко}

Аннотация. В статье раскрыто важность критериально-уровневого оценивания развития музыкально-творческих способностей детей в музыкальной деятельности. Определены критерии и показатели развития музыкально-творческих способностей детей 6-7 лет во внешкольных учреждениях. Освещены уровни развития музыкально-творческих способностей детей 6-7 лет с учётом компонентов личности, которые определяют структуру музыкально-творческих способностей воспитанников. Доказана необходимость экспериментального исследования с целью подтверждения или опровержения разработанных критериев, показателей и уровней.

Ключевые слова: критериально-уровневое оценивание, критерии, показатели, уровни развития, музыкально-творческие способности, дети 6-7 лет, внешкольные учреждения. 


\title{
Готовність до інноваційної педагогічної діяльності як запорука формування у майбутніх вихователів закладів дошкільної освіти культури самовираження
}

\author{
І. А. Онищук \\ Кременецька обласна гуманітарно-педагогічна академія ім. Тараса Шевченка, м.Кременець, Тернопільська область, Україна \\ Corresponding author. E-mail: ionuschyk@gmail.com
}

Paper received 05.06.18; Accepted for publication 12.06.18.

\author{
https://doi.org/10.31174/SEND-PP2018-170VI70-10
}

\begin{abstract}
Анотація. У статті висвітлюються деякі аспекти проблеми підготовки та готовності майбутніх фахівців дошкільної освіти до інноваційної педагогічної діяльності. Зокрема, акцентується на тому, що готовність до інноваційної педагогічної діяльності $є$ важливою складовою розвитку культури самовираження студентської молоді у закладі вищої освіти, оскільки пов'язана $з$ творчою самореалізацією майбутнього педагога. Також у публікацііі на основі аналізу психолого-педагогічної літератури розкриваються компоненти, критерії і показники культури самовираження майбутніх фахівці дошкільної освіти та окреслено перспективу подальшого наукового пошуку.
\end{abstract}

Ключові слова: творчість, готовність до інноваџійної педагогічної діяльності, культура самовираження, майбутні вихователі закладів дошкільної освіти.

Інтенсивні процеси трансформації системи освіти нашої держави зумовили необхідність якісних змін у підготовці майбутніх педагогів, оскільки суспільство гостро потребує фахівця здатного продукувати нові прогресивні ідеї, знаходити нестандартні й ефективні вирішення проблем, проявляти творчість, готового до інноваційної педагогічної діяльності загалом. Освіта, за висновками I. Зязюна, як педагогічний феномен $\epsilon$ однісю із значущих складовою суспільства, метою якої є виховання особистості як суб'єкта, який відображає культуру людства і відчуває свою відповідальність перед майбутнім, яке залежить від його поведінки сьогодні [4, с. 11]. Зокрема, Національна доктрина розвитку освіти України у XXI столітті, Закон «Про освіту», «Про вищу освіту» проголошують пріоритет становлення молодої людини як свідому особистість та суб'єкта власного життя. Варто зазначити, що враховуючи особливості сьогодення, труднощі епохи радикальних змін, особливо гостро ця проблема постає для закладів вищої освіти у процесі підготовки майбутніх вихователів закладів дошкільної освіти - педагогів-гуманістів, які покликанні першими реагувати на виклик сучасності, по-новому сприймати систему «педагог - дитина», створювати сприятливі умови для прояву зростаючою особистістю різних форм активності з врахуванням іiі індивідуальності $[1 ; 3 ; 5 ; 8 ; 10 ; 11 ; 12]$. Отож, на часі реалізація особистісно-орієнтованого підходу у педагогічній освіті, в центрі якої повинні бути інновації, що сприятиме самовираженню, самовизначенню та самореалізації підростаючому поколінню. 3 огляду на це, сучасний педагог закладу дошкільної освіти повинен не тільки мати базові знання та уміння, а й володіти новітніми освітніми технологіями, бути здібним до інноваційної педагогічної діяльності. За останні роки інноваційна педагогічна діяльність привертає увагу науковців різних галузей: філософії, психології, педагогіки та інших.

Аналіз психолого-педагогічної літератури засвідчив накопичення значного доробку, який розкриває основні аспекти досліджуваного явища: розвиток особистості в процесі професійного становлення (К.
Абульханова-Славська, Б. Ананьєв, І. Бех, Л. Божович, Л. Виготський, О. Леонтьєв, В. Кремень, В. Луговий, О. Сухомлинська, Л. Рубінштейн та інші); становлення особистості як суб'єкта педагогічної діяльності, цілісності його професійно-педагогічної підготовки (В. Бондар, Н. Бібік, В. Кузь, С. Гончаренко, В. Гриньова, В. Загвязинский, І. Зязюн, Н. Кичук, В. Кравець, М. Кузьміна, Н. Ничкало, С. Максименко, О. Пєхота, О. Пометун, В. Семиченко, С. Сисоєва, В. Сластьонін, Р. Хмелюк, А. Хуторськой, Н. Юсуфбекова та інші); особливості інноваційної педагогічної діяльності вихователя ЗДО (Л. Артемова, Г. Белєнька, А. Богуш, Н. Гавриш, Т. Жаровцева, А. Залізняк, Л. Зданевич, І. Дичківська, Л. Загородня, Н. Денисенко, І. Луценко, Н. Лисенко, О. Листопад, М. Машовець, I. Мардарова, Т. Поніманська, І. Рогальськаяблонська).

Про те зазначена проблема формування готовності майбутніх фахівців дошкільної освіти до інноваційної педагогічної діяльності як запорука культури самовираження спеціально не розглядалася. Таким чином, вивчення готовності майбутніх фахівців дошкільної освіти до інноваційної педагогічної діяльності як важливої умови розвитку їхньої культури самовираження зумовлене наявністю суперечності між замовленням сучасного суспільства на підготовку фахівця нової формації та традиційною організацією освітнього процесу у закладі вищої освіти, недостатньою іiї зорієнтованістю на розвиток у студентської молоді потреби та здатності до культурного самовираження, вияву творчого потенціалу.

3 огляду на зазначене, метою статті є висвітлення значення готовності до інноваційної педагогічної діяльності майбутніх фахівців дошкільної освіти у процесі їхньому самовизначення.

Виклад основного матеріалу. Як засвідчили фахівці $[3 ; 5 ; 8 ; 10 ; 11 ; 14]$, сучасна система дошкільної освіти потребує вихователів нового типу, яким притаманні якості, такі як: відкритість до нововведення та готовність досягати якісно нових результатів (уміння сприймати дійсність відповідно до змін, які відбуваються); фахова компетентність (здатність повною мі- 
рою реалізовувати набуті теоретичні знання у практичній діяльності); методологічна культура, завдяки чому освітній процес у сучасному закладі дошкільної освіти вдається вибудувати цілісно, на науковому підгрунті, що дозволяє в свою чергу успішно реалізувати освітню мету та отримувати очікуванні результати; педагогічна творчість, яка базується на фундаментальних теоретичних положеннях, досягненнях сучасної науки, практики та творчій ініціативі.

Логіка розпочатого наукового пошуку потребує висвітлення поняття «інноваційна діяльність», «інноваційна педагогічна діяльність», «творча діяльність», «культура самовираження майбутнього вихователя ЗДО». Науковці підкреслили, що за своєю суттю інноваційна діяльність пов'язана з процесом взаємодії індивідів та спрямована на розвиток, перетворювання об’єктів в якісно нові. Феномен «інноваційна педагогічна діяльність» тлумачиться як цілеспрямована педагогічна діяльність, орієнтована на зміну й розвиток освітнього процесу 3 метою досягнення якісно вищих результатів (одержання нових знань та практичних умінь $з$ врахуванням педагогічного досвіду) [3, с. 76].

До основних функцій інноваційної педагогічної діяльності належить зміна компонентів педагогічного процесу, їхнє оновлення відповідно до сучасних вимог - мета, зміст, форми, методи, технології, засоби, система управління та інше. Результатами або ж «продуктами» інноваційної педагогічної діяльності, зазначають фахівці, є нововведення, які спричиняють позитивні зміни в системі освіти та водночас слугують чинниками іiі розвитку [3; 14;15]. Інноватика у системі освіти пов'язана 3 нововведеннями, їхньою оцінкою, засвоєнням та реалізацією на практиці. До складових компонентів «педагогічної інноватики», як зазначив А. Хуторськой, належать [14]: зміст освіти (плани, програми, методичне забезпечення тощо); організація освітнього процесу в закладі освіти; система ставлень «педагог - зростаюча особистість»; методи освітньої діяльності та інше. Таким чином, інноваційна педагогічна діяльність є особливим видом творчої діяльності, спрямованої на формування професійної компетентності та реалізації творчого потенціалу педагога.

Відповідно до контексту дослідження виникає потреба з'ясувати поняття «творчість», «творча активність», «творче самовираження» майбутнього педагога та інше. У працях з філософії наявні різні підходи до визначення феномену «творчість». До прикладу, можна навести такі узагальнення як: діалектична, суперечлива діяльність, що може здійснюватися на свідомому така і на підсвідомому рівнях (Й. Фіхте); містично-споглядальна інтуїція, самодіяльна активність суб'єкта (I. Кант); випадкова асоціація, ефект поєднання раніше не пов'язаних подій (Б. Кедров); необхідна умова розвитку матерії, утворення іï нових форм, разом з якими змінюються й самі форми творчості (Г. Батіщев); свідома діяльність людей, спрямована на отримання якісно нових, соціально значущих результатів, шляхом цілеспрямованого вирішення суперечностей дійсності (С. Семенов); діяльність, у процесі якої особистість вільно й конструктивно реалізує себе, виражає своє «Я» (Р. Апресян). Доречно зазначити, що на сьогодні у науковому доробку про- блема творчості, творчої активності розглядається у контексті «самодіяльності» та «саморозвитку». Зокрема, дефініція «творчість», «життєтворчість» (за Л. Сохань, В. Шинкаруком, Н. Шульгою) пов'язана 3 процесом самопізнанням, самоактуалізації, підгрунтям якого є духовність особистості, її світогляд, мета, прагнення, тобто розуміння сенсу життя.

В контексті нашого дослідження варто зазначити, що науковці 3-поміж видів творчої активності, які безпосередньо пов'язані 3 інноваційною педагогічною діяльністю виокремлюють $[3 ; 4 ; 8 ; 12 ; 14]$ : модифіковану - ii суть полягає в раціоналізації, оновленні освітніх програм, методів та прийомів та іншого. За допомогою модифікованого механізму творчої діяльності створюється педагогічний продукт, який вже мав місце у педагогічні практиці, але удосконалений відповідно до вимог сучасності; комбіновану передбачає об'єднання елементів відомих на даний час освітніх програм, методик, педагогічних технологій $з$ метою їх осучаснення; радикальну - передбачає напрацювання в галузі освіти на основі принципово нових ідей, які до цього часу не мають аналогів у педагогічній теорії та практиці.

3 огляду на це, майбутньому педагогу-творцю, у тому числі вихователю ЗДО повинні бути притаманні такі якості як ініціативність, самостійність, здатність до подолання інерції мислення, почуття нового, внутрішня мотивація на творчу педагогічну діяльність [2; $3 ; 4 ; 6 ; 8 ; 10 ; 11 ; 12 ; 13 ; 14]$. Саму тому важливим, на наш погляд, постає питання підготовки майбутніх педагогів до інноваційної педагогічної діяльності як запоруки розвитку культури самовираження. Підготовка майбутніх фахівців дошкільної освіти, за визначеннями науковців, має багатокомпонентну, складну структуру; першочерговим завданням у даному процесі $є$ набуття кожним студентом закладу вищої освіти особистісного смислу діяльності, формуванні фахової майстерності, стійкому інтересі до роботи із зростаючою особистістю та іï батьками, а також у розвитку успішності в діяльності [10, с. 101].

Професійну підготовку фахівців дошкільної освіти, М. Васильєва, визначає як спрямовану, організовану, планомірну, змістовну й динамічну систему діяльності суб'єктів навчально-вихованого процесу у вищому педагогічному навчальному закладі, мета, якої формування у майбутніх педагогів усіх видів компетентності, потрібних для успішної професійної діяльності [2, с. 37]. Сучасні реалії, за висновками Т. Поніманської, орієнтують на спеціальну підготовку вихователя як гуманістично зорієнтованої особистості, здатної оперативно реагувати на динаміку соціальноекономічних процесів, умов власної професійної діяльності, розробляти і впроваджувати нові технології у освітній процес [11].

Ефективність процесу формування готовності майбутніх педагогів до інноваційної діяльності як запоруки культури самовираження у закладі вищої освіти залежить від розуміння суті феномену «готовність», «готовність до інноваційної педагогічної діяльності». «Готовність» у довідкових джерелах тлумачеться як погодженість виконувати роботу; стан, при якому все зроблено, все реалізовано. Зазначимо, що складність дослідження у галузі педагогіки полягає в тому, що 
єдиного визначення даних понять не існує, оскільки науковці розглядають їх у різних аспектах, зокрема: прояв здібностей (Б. Ананьєвим); комплекс властивостей особистості, який сприяє успішності діяльності (В. Крутецький); цілісне динамічне утворення, що набувається внаслідок спеціального навчання (А. Боровков); чітке і системне оволодіння певними знаннями й уміннями, стійка переконаність, соціальназначуща спрямованість особистості (І. Зимня); цілісна інтегрована якість особистості, що характеризує іiі емоційно-когнітивну і вольову мобілізаційність у момент включення в діяльність визначеної спрямованості; виникає в результаті певного досвіду людини, що грунтується на формуванні іiі позитивного ставлення до професійної діяльності, усвідомленні мотивів і потреб у ній [7]. За І. Зязюном, повноцінна готовність педагога це не лише параметри діяльності і не лише якості особистості, а їх діалектична єдність і представленість у конкретній людині [4].

Наведені визначення дають можливість чітко визначити роль і завдання закладу вищої освіти щодо формування у студентської молоді готовності до інноваційної педагогічної діяльності у контексті проблеми формування їхньої культури самовираження

Таким чином, аналіз наукових праць, можна стверджувати, що готовність до інноваційної педагогічної діяльності $\epsilon$ важливою умовою розвитку культури самовираження майбутніх фахівців дошкільної освіти.

Як показав аналіз психолого-педагогічної літератури, культура самовираження майбутнього вихователя ЗДО має прояв у наступному: особливостях (відмінних від інших людей властивостях), способах (систематизовані сукупності дій, спрямовані на досягнення мети); результатах (проміжні та кінцеві продукти); самоорганізованій діяльності. Провідною ідеєю кон- цепції є положення, згідно з яким культура самовираження майбутнього фахівця дошкільної освіти $є$ особистісним інтегралом; проявляється у самоорганізованій діяльності (цілепокладанні, мотивації, способах дій, проміжних й кінцевих продуктах) та визначається системою пріоритетних життєвих, професійних та культурологічних цінностей.

Критеріями оцінки міри сформованості культури самовираження виступають властивості особистості майбутнього вихователя закладу дошкільної освіти, відповідні основним векторам педагогічної діяльності - діловому, асксіологічному, комунікативному, перетворювальному. У закладі вищої освіти успішність розвитку культури самовираження випускника визначається мірою збалансованості його знань, ставлення й поведінки; засвідчується силою, модальністю та стійкістю проявів організованості, зацікавленості, комунікативної толерантності та креативності.

Висновки. Розробка нових підходів до освітнього процесу закладів вищої освіти є ведучою та необхідною тенденцією його розвитку, оскільки в центрі підготовки фахівця повинні стояти інноваційні процеси, як поєднують в собі засвоєння, застосування та створення педагогічної інноватики.

Як показав аналіз психолого-педагогічної літератури підготовка до інноваційної педагогічної діяльності майбутніх вихователів закладів дошкільної освіти $є$ необхідною формування їхньої культури самовираження як особистісного феномену.

Перспективу подальшого наукового пошуку вбачаємо у обгрунтуванні та впровадженні педагогічних умов формування готовності майбутніх вихователів ЗДО до інноваційної педагогічної діяльності як необхідної складової їхньої культури самовираження.

\section{ЛІТЕРАТУРА}

1. Базовий компонент дошкільної освіти: Науковий керівник: А. М. Богуш, дійсний член НАПН України, проф., др пед. наук.; Авт. кол-в: Богуш А. М., Бєлєнька Г. В., Богініч О. Л., Гавриш Н. В. та ін. - К. : Видавництво, 2012. $26 \mathrm{c}$.

2. Васильєва М.П. Культурологічний підхід до процесу професійної підготовки майбутнього педагога / М.П. Васильєва // Педагогіка і психологія творчої особистості: проблеми і пошуки: зб. наук. праць. Вип. 47. - Запоріжжя, 2007. - C. 67.

3. Дичківська І.М.Інноваційні педагогічні технології. Практикум : навчальний посібник / I.М. Дичківська. _ К. : Видавничий Дія «Слово», 2013. - 448 с.

4. Зязюн I. А. Концептуальні засади теорії освіти в Україні // Іван Андрійович Зязюн // Педагогіка і психологія професійної освіти. - 2000. - № 1. - С. 11-24.

5. Кононко О. Л. Культура самовираження майбутніх педагогів як особистісний феномен / Збірник тез наукових робіт учасників міжнародної науково-практичної конференції «Психологія та педагогіка: необхідність впливу науки на розвиток практики в Україні». - м. Львів: ГО «Львівська педагогічна спільнота». - 2017. - С. 13-18.

6. Кремень В. Г. Освіта і наука в Україні - інноваційні аспекти. Стратегія. Розвиток. Результати / Василь Григорович Кремень. - К. : Грамота, 2005. - 448 с.

7. Линенко А. Ф. Педагогічна діяльність і готовність до неї : монографія / А. Ф. Линенко. - О. : ОКФА, 1995. - 80 с.

8. Листопад О.А. Теоретико-методологічні засади формування професійно-творчого потенціалу майбутніх вихователів дошкільних навчальних закладів : монографія / О.А. Листопад. - Одеса : ФОП Бондаренко М.О., 2015. $328 \mathrm{c}$.

9. Омельченко Е .А. Самовыражение и культура самовыражения педагогов и студентов педагогических ВУЗов // Теория и практика образования в современном мире: материалы П международной научной конференции. - СПб. : Реноме. - 2012. - С.11-14.

10. Підготовка вихователя до розвитку особистості дитини в дошкільному віці : монографія / Г. В. Бєлєнька, О. Л. Богініч, 3. Н. Борисова та ін. ; за заг. ред. І. І. Загарницької. - К. : Вид-во НПУ імені М. П. Драгоманова, 2009. $310 \mathrm{c}$.

11. Поніманська Т. І. Дошкільна педагогіка : навчальний посібник для студентів вищих навчальних закладів / Т. I. Поніманська. - К. : Академ- видав, 2006. - 456

12. Сисоєва С.О. Основи педагогічної творчості: Підручник / С.О. Сисоєва. - К.: Мілені, ум, 2006. - 344 с.

13. Хуторской А. В. Педагогическая инноватика: методология, теорія, практика. Научное издание / А. В. Хуторской. - М. : Изд-во ДО, 2005. - 222 с.

14. Чайка В.М. Проблеми змісту підготовки майбутніх вихователів дошкільних навчальних закладів до інноваційної педагогічної діяльності / В.М. Чайка // Наукові записки. Серія : Педагогіка. - 2012. - № 2. - С. 33- 39. 


\section{REFERENCES}

1. Basic component of preschool education: Scientific supervisor: A. M. Bogush, active member of the National Academy of Sciences of Ukraine, Prof., Dr. Ped. Sciences . : Group of authors: Bogush A. M., Belenka G. V., Bohinich O. L., Gavrish N.V. and others. - K . : Publishing House, 2012. $-26 \mathrm{p}$.

2. Vasilieva M. P. Cultural approach to the process of professional training of the future teacher / MP Vasiliev / / Pedagogy and psychology of creative personality: problems and searches: Sb. sciences works. Edition 47. Zaporizhzhia, 2007. - P. 67.

3. Dychkivska I. M. Innovative pedagogical technologies. Workshop: tutorial / I.M. Dychkivska _ K .: Publishing House "Slovo" ( "Word"), 2013. - 448 pp.

4. Zyazun I. A. Conceptual Principles of the Theory of Education in Ukraine // Ivan Andriyovych Zyazyun // Pedagogics and Psychology of Vocational Education. 2000. - No. 1. - P. $11-24$.

5. Kononko O. L. The culture of self-expression of future teachers as a personal phenomenon / Collection of abstracts of scientific works of the participants of the international scientific and practical conference "Psychology and pedagogy: the need for science to influence the development of practice in Ukraine". - Lviv city: public organization "Lviv Pedagogical Community". - 2017. - P. 13-18.

6. Kremin V. G. Education and science in Ukraine - innovative aspects. Strategy. Development. Results / Vasyl Grygorovych Kremen. - K.: "Hramota" (Diploma), 2005. - 448 p.
7. Linenko A. F. Pedagogical activity and readiness for it: monograph / A.F.Linenko. - O.: OKFA, 1995. - 80 p.

8. Lystopad O. A. Theoretical and methodological principles of formation of professional-creative potential of future teachers of pre-school educational institutions: monograph / Lystopad O.A. - Odessa: Bondarenko M. O., 2015. - 328 p.

9. Omelchenko E.A. Self-expression and culture of selfexpression of teachers and students of pedagogical universities // The theory and practice of education in the modern world: materials of the II international scientific conference. - St. Petersburg : Renome - 2012. - P. 11-14.

10. Preparation of the educator for the development of the child's personality in preschool age: monograph / G.V. Belenka, O. L. Bohinich, Z. N. Borisova and others. ; according to the general edition of I. I. Zaharnytska. - K. : NPU named after MP Drahomanov, 2009 - 310 p.

11. Ponimanska T. I. Preschool Pedagogy: Textbook for Students of Higher Educational Establishments / T. I. Ponimanska. - K. : Academician, 2006 - 456 p.

12. Sysoev S.O. Fundamentals of Pedagogical Creativity: Textbook. - K .: Milenium, 2006. - 344 p.

13. Khutorskoy A. V. Pedagogical Innovation: Methodology, Theory, Practice. Scientific publication / A. V. Khutorskoy. - Moscow: Publishing House, 2005. - 222 p.

14. Chayka V.M. Problems of content of training of future educators of preschool educational institutions for innovative pedagogical activity / V.M. Chayka // Scientific Notes. Series: Pedagogy. - 2012. - No. 2. - P. 33-39.

Readiness for innovative pedagogical activity as a pledge of forming the culture of self-expression of future educators for preschool educational establishments

I. A. Onyshchuk

Abstract. The article covers some aspects of the problem of preparation and readiness of future preschool education specialists for innovative pedagogical activities. In particular, the emphasis is made on the fact that readiness for innovative pedagogical activity is an important component of the development of the young students' culture of expression in the establishments of higher education , as it is associated with the creative self-realization of the future teacher. Also in the article, based on the analysis of psychological and pedagogical literature, the components, criteria and indicators of the culture of self-expression of future specialists of preschool education are highlighted and the prospect of further scientific research is outlined.

Keywords: creativity, readiness for innovative pedagogical activity, culture of self-expression, future educators of pre-school education establishments.

Готовность к инновационной педагогической деятельности как залог формирования культуры самовыражения будущих педагогов для дошкольных образовательных учреждений

\section{И. А. Онищук}

Аннотация. В статье раскрываются некоторые аспекты проблемы подготовки та готовности будущих воспитателей дошкольных учереждений к инновационной педагогической деятельности. Особенно акцентируется на том, что готовность к инновационной педагогической деятельности выступает важным условием развития культуры самовыражения студентов, которая взаимосвязана с творческой самореализацией будущего педагога. Также в публикации на основе анализа психолого-педагогической литературы определены компоненты, критерии та показатели культуры самовыражения будущих воспитателей, перспектива научного поиска.

Ключевые слова: творчество, готовность до инновачионной педагогической деятельности, культура самовыражения, будущие воспитатели дошкольных учереждений. 


\title{
Деякі аспекти вивчення особистісного фактору екології людини
}

\author{
І. Л. Плаксієнко, П. В. Писаренко, М. С. Самойлік, Л. А. Колєснікова
}

\author{
Полтавська державна аграрна академія, Україна \\ Corresponding author. E-mail: irinaplaksienko@gmail.com \\ Paper received 25.05.18; Accepted for publication 01.06.18.
}

\section{https://doi.org/10.31174/SEND-PP2018-170VI70-11}

\begin{abstract}
Анотація. В статті обгрунтовується доцільність вивчення екології особистості як складової навчальної дисципліни «Екологія людини» при підготовці фахівців у галузі екології, підкреслюється важливість особистісного фактору при формуванні екологічного світогляду студентів. Використання такого методологічного підходу позитивно впливає на засвоєння студентами фундаментальних теоретичних знань з екології людини, сприяє самопізнанню та забезпечує умови для самореалізації творчого потенціалу студентів.
\end{abstract}

Ключові слова: екологія людини, екологія особистості, самопізнання, адаптаційний потенціал людиниі, екологічний світогляд.

Вступ. Розвиток сучасного суспільства супроводжується стрімким розширенням і поглибленням глобальних екологічних проблем, тому система оцінки стану екосистем стає багатовимірною: медикобіологічною, соціальною, економічною, моральною. Науковці різних галузей наук давно прийшли до висновку, що людину і біосферу слід розглядати в комплексі як єдиний організм, стан якого залежить від здоров'я всіх його складових. В нашому столітті людство зіткнулося з серйозними наслідками своєї діяльності в ході науково-технічної революції. Завдяки науково-технічному прогресу ми домоглися певного контролю над силами природи, але недбайливе відношення до природи призвело до катастрофічного антропогенного забруднення навколишнього середовища, втрати гармонійного зв'язку людини 3 природою і навіть спровокувало проблему виживання людства [11].

Для успішної біологічної адаптації людини в умовах глобалізації необхідне впровадження новітніх соціально-біологічних програм адаптації, що зумовлює підвищення ролі особистості людини, бо саме особистісні, соціальні та моральні якості людини визначатимуть ефективність їі діяльності в сучасних природних умовах. Для подолання глобальних проблем людство має переосмислити стиль і способи, технології й загальну практику свого ставлення до природи, оточуючого середовища загалом, до пошуку нової філософії життєдіяльності людства, гармонізації взаємодії системи людина-суспільство-природа [1] Без сумніву серйозні екологічні проблеми може вирішувати тільки самодостатня, гармонійна і творча людина, із сформованим екологічним світоглядом, який являє собою єдність екологічного знання, культури і екологічної діяльності. В сучасних умовах особливої гостроти набуває розвиток особистісної складової екології людини. У людини з'являються і поступово зростають необмежені можливості формування біологічно неуспадковане унікальних особистісних властивостей, які разом 3 відповідними соціальними умовами можуть створювати основу для іiї всебічного розвитку і самореалізації [8].

Короткий огляд публікацій. Екологія людини $є$ досить різноплановою наукою, вона включає широкий спектр питань, пов'язаних як з біологічною так i соціальною природою людини. Екологія людини на- самперед розвивалась як напрям досліджень, в якому людина розкривається $з$ санітарно-медичних позицій як окремий представник Ноmo sapiens. У сучасній парадигмі екологія людини характеризується дослідженням відносин і зв'язків індивіда 3 природним, техногенним і соціокультурним середовищем, тобто вивченням досить широкого кола суб'єкт-суб'єктних і суб'єкт- об'єктних взаємовпливів [6]. Теоретичні та прикладні аспекти екології людини стали предметом наукового пошуку багатьох українських науковців у вітчизняному освітньому процесі (Г.С. Халецький, Л.І. Соломенко, I.І. Залецький, Т.В. Кириєнко, М.О. Клименко, А.Н. Некос, І.І. Дуднікова, Я.Б. Олійник та ін.).

У науковій та навчально-методичній літературі поряд з традиційними проблемами взаємодії в антропоекосистемі, такими як закономірності взаємодії людини 3 навколишнім середовищем, вплив природних та антропогенних екологічних чинників на здоров'я людини, екологічна безпека людства, еволюція та закономірності механізмів адаптації людини на індивідуальному та популяційному рівнях, пристосування людського організму до техногенних змін навколишнього середовища розглядаються і демографічні проблеми людства $[3,9,10]$, походження і еволюція людини [10], особливості анатомо-фізіологічних функцій організму сучасної людини [7]; космічна антропоекологія [7, 14], різнобічні аспекти здорового способу життя $[7,9,14,15]$.

Деякі вчені приділяють також увагу питанням гармонійного i духовного розвитку особистості [10], психічної адаптації людини [9, 10], екології соціального середовища, екологічної культури та їі складових $[14,15]$. Науковцями наголошується, що успіх у вирішенні проблем вдосконалення біологічної та соціально-психологічної адаптації людини, збереження популяції людства у цілому в наш час визначається виконанням цільового принципу, спрямованого на оптимізацію відношення людини до навколишнього середовища за рахунок їі високих інтелектуальних та моральних особистісних якостей [2]. Отже, вивчення особистісного фактору екології людини на шляху іiі самоусвідомлення та усвідомлення нею своєї ролі у вирішенні екологічних проблем $є$ нагальним завданням.

Метою статті є розробка та впровадження методо- 
логічних засад щодо вивчення особистості як складової навчальної дисципліни «Екологія людини» студентами зі спеціальності «Екологія».

Матеріали та методи. Для розробки методологічних засад стосовно дослідження особистісної складової екології людини були опрацьовані наукові та навчально-методичні [4,5] праці вітчизняних вчених в галузі екології людини та соціальної екології [13]. Проаналізовано результати викладення лекційного матеріалу та проведення практичних занять $з$ екології особистості зі студентами академії за спеціальністю «Екологія». В якості інструментів навчальної, діагностичної та розвивальної роботи на практичних заняттях 3 курсу «Екологія людини» та в позааудиторний час за участю психологічної служби академії проводились тестування та міні-тренінги 3 використанням арт-методів [12].

Результати та їх обговорення.

Дисципліна «Екологія людини» викладається у вищих навчальних закладах студентам різних спеціальностей як природничого, так і гуманітарного напряму. Ця дисципліна $є$ нормативною для студентів зі спеціальностей «Екологія», «Охорона навколишнього середовища та збалансоване природокористування». У найбільш широкому розумінні екологія людини $\epsilon$ міждисциплінарною наукою, яка досліджує закономірності взаємодії людини і в цілому популяції людей з довкіллям, вплив факторів зовнішнього середовища на функціонування людського організму, цілеспрямоване управління збереженням та поліпшенням здоров'я населення [15]. Головним завданням екології людини окреслюється збереження здоров'я людей, удосконалення фізичних i психічних можливостей людини в сучасній антропоекосистемі. Для студентівекологів не передбачено вивчення соціальної та психологічної екології, тож розгляд особистісних та соціальних аспектів взаємодії людина - природне середовище також покладається на дисципліну «Екологія людини».

Нами запропоновано в робочій навчальній програмі дисципліни «Екологія людини» виділити в окремий розділ дослідження екології особистості, метою якого $€$ застосування теоретичних положень в галузі соціальної психології, валеології, елементів психології особистості та розвитку, психофізіології для усвідомлення студентами ролі особистості в гармонізації взаємодії людина-природа та набуття навичок з формування інтелектуального та морального потенціалу майбутніх фахівців за рахунок саморозвитку та самовдосконалення.

До лекційного матеріалу у розділ «Екологія особистості» увішли такі питання:

Особистість - як феномен одночасно індивідного і соціального буття.

Осмислення різних законів і механізмів розвитку особистості в сучасній екологічній парадигмі.

Світосприйняття та екологічний світогляд сучасної людини, які спираються на усвідомлення єдності природи і людини, знання законів природи.

Елементи психогігієни та валеології. Екологія емоцій.

Психічна адаптація як процес встановлення оптимальної відповідності особистості стану навколиш- нього середовища в ході здійснення професійної діяльності.

Адаптованість та переадаптація, як механізм організації нового рівня діяльності людини.

Інтелектуальний і моральний потенціали здоров'я людини як основна характеристикою рівня розвитку держави та її культурного надбання.

Характеристика приорітетів еколога, як самодостатньої зрілої особистості.

Для засвоєння теоретичного матеріалу запропоновано практичні заняття за темами:

1. «Психофізіологічний портрет людини». Метою якого є знайомство з методами діагностики індивідуальних характеристик особистості, визначення індивідуальних характеристик особистості за тестами 3 властивостей вищої нервової системи (тест Стреляу), темпераменту (тест Айзенка), особистості (16факторний опитувальник Кеттела) та ін. В позааудиторний час психологічною службою академії проводились психодіагностичні заняття 3 використанням проективного малювання (малюнки «Невідома тварина», «Кактус» та ін.).

2. «Формування та збереження адаптаційного потенціалу людини в різних умовах ії життєдіяльності». На цьому практичному занятті обговорюється динаміка адаптації людини до факторів зовнішнього середовища, розвитку і старіння; складові психічного та психологічного здоров'я людини, які входять до адаптаційного потенціалу людини, що особливо важливо в епоху негативного впливу психоемоційних факторів; шляхи здорової адаптації до життєвого простору, які ведуть до стану гармонійної рівноваги людини та навколишнього середовища. Для характеристики психічного стану використано тести САН, психоемоційного стресу Люшера, реактивної тривожності Спілбергера-Ханіна. Розглядаються методи психоемоційного розвантаження та формування стресостійкості (дихальні вправи, практики цигун).

3. «Подорож до самого себе». На практичному занятті студенти визначають і обговорюють свої життеві цінності та домагання, знайомляться 3 етапами формування «Я-концепції», Для формування позитивної Я-концепції використовуються такі проективні малюнкові методики, як «Автопортрет» «Грані мого Я», «Дерево життя». Заняття націлене на формування адекватної самооцінки студентів, їх позитивного ставлення до світу, усвідомлення ними своєї професійної спрямованості, мотивації до самоактуалізації та самоудосконалення.

На дискусійне обговорення на семінарі винесено відомі аксіоми кращих мислителів людства:

«Легше всього жити у відповідності зі своєю природою і тому іiі потрібно знати» (Марк Аврелій),

«Природа не робить людей, люди роблять себе самі» ( Мераб Мамардашвілі),

«Якщо хочеш перемогти весь світ, переможи самого себе» (Федір Достоєвський),

«Бути особистістю - це значить бути самостійним джерелом дії» (Е. Дюркгейм),

«Якщо людина хоче прийти до самого себе, його шлях лежить через світ» ( В.Франкл),

«Доля людства - в руках людини» (В. Гжещік), «Щоб бути собою, треба бути кимось» «Станіслав 
Сжи Лец),

«Найважча професія бути людиною» (Х. Марті),

«В основі могутності лежить могутність особистості» (Н. Хілл),

«Особистістю не народжуються, особистістю стають» (О.М. Леонтьєв).

Для самостійного опрацювання запропоновані такі теми: «Елементи екологічної етики», «Моральні якості і властивості, що регулюють індивідуальну поведінку людини», «Моральний аспект взаємовідносин людини, суспільства і природи», «Екологія емоцій», «Профілактика та корекція дезадаптацій за допомогою східної медицини», «Принципи здорового способу життя».

Тож, вивчення дисципліни «Екологія людини» можна вважати одним із способів формування у екологів усвідомлення ролі і завдань людини у вирішенні екологічних проблем і стабілізації екологічної ситуації в світі. Аналіз результатів впровадження в навчальний курс «Екологія людини» розділу «Екологія особистості» дає підстави стверджувати, що викладений матеріал сприяє засвоєнню студентами фахових завдань, здатності їх до самопізнання та саморозвитку. Залучення до навчальної роботи арт-методів як засобів діагностичної та розвивальної роботи сприяють самопізнанню і самовираженню студентів через мистецтво та розвиток їх здібностей до конструктивних дій 3 урахуванням реалій навколишнього світу [12].

Висновки. Прогрес суспільства багато в чому визначається рівнем інтелектуального i морального потенціалу людини, тож вивчення екології людини як науки має грунтуватися на екології особистості людини, іiі гуманітарно-етичних цінностях. Провідними передумовами формування фахівців у галузі екології $\epsilon$ вивчення особистісних культурно-духовних детермінант людини.

Запропоновані методологічні заходи урахування та вивчення особистісної складової екології людини позитивно позначаються на оволодінні студентами базових знань та умінь 3 екології. Розгляд екології особистості виконує інформаційну (форми і способи гармонійного співіснування людини 3 довкіллям), практично-розвивальну (розвиток у студентів навичок 3 аналізу особистісних характеристик людини, саморегуляції, становлення гармонійної особистості) та виховну функцію.

Такий методологічний підхід до вивчення дисципліни «Екологія людини» при підготовці фахівців у галузі екології сприяє забезпеченню умов самореалізації творчого потенціалу студентів, зв'язку фундаментальних теоретичних знань із особистісними практичними професійними навичками та вміннями, що формує активну життєву позицію і високу відповідальність фахівців у галузі екології в еру глобалізації.

\section{ЛІТЕРАТУРА}

1. Агаджанян Н.А. Экология человека. Избранные лекции / Н.А Агаджанян., В.И Торшин.- М.: Крук, 1994.- 256 с.

2. Агаджанян Н.А. Экология человека в системе современного научного знания и глобальные проблемы человечества / Н.А. Агаджанян, А.Е. Северин, В.И. Торшин, Н.Е. Аймаутова и др.- Вестник РУДН.-Серия «Социология».2002.- №1. - С. 74-94.

3. Гора Е.П. Экология человека /Е.П. Гора.- М.: Дрофа, 2007. $-540 \mathrm{c}$

4. Гора Е.П. Экология человека. Практикум /Е.П. Гора.- М.: Дрофа, 2008. - 127 с

5. Губарева Л. И. Экология человека: практикум для вузов / Л. И. Губарева, О. М.Мизирева, Т.М. Чурилова - М.: ВЛАДОС, 2005. - $112 \mathrm{c}$.

6. Дуднікова I.I. Соціально-філософський дискурс екології людини / І.І.Дуднікова // Гуманітарний вісник ЗДІА. Філософія. - 2009 - Вип.37.- С.226-233.

7. Залецький I.I. Екологія людини / I.I. Залецький, М.О. Клименко //К.: Вид. центр «Академія», 2005.-288 с.

8. Кармаев Н.А. Современные проблемы экологии человека // Отчуждение человека в перспективе глобализации мира. Вып. 1 /Сборник философских статей. под ред. Маркова Б.В., Солонина Ю.Н., Парцвания В.В. С.-П. : Издаво «Петрополис», 2001. С.87-99.

9. Кириєнко Т.В. Екологія людини: курс лекцій для сту-

дентів природничо-географічного факультету / Т.В. Кириєнко - Вінниця: ПП «Друкарня «Твори» », 2015. -176 c.

10. Некос А. Н. Екологія людини: підручник / А. Н. Некос, Л. О. Багрова, М. О. Клименко. - Х.: ХНУ ім. В. Н. Каразіна, 2013. - $284 \mathrm{c}$.

11. Олійник Я. Б. Основи екології: підручник / Я. Б. Олійник, П. Г. Шищенко, О. П. Гавриленко. - К.: Знання, 2012. $-558 \mathrm{c}$.

12. Плаксієнко І. Л.. Окремі аспекти організації психологічного супроводу навчально-виховного процесу у вищій школі / І.Л., Плаксієнко, І.М.Шупта, А.А. Кочерга // Науковий вісник НУБіП України. Серія «Педагогіка. Психологія. Філософія».-К.: ВЦ НУБіП України.-2014.Вип.199.-Ч.2.-С.233-239.

13. Ситаров В.А. Социальная экология: уч. пособие для студентов висш. пед. учебн. заведений.- М.: Изд. Центр «Академия», $2000-280$ с.

14. Соломенко Л. І. Екологія людини: навчальний посібник /Л.І. Соломенко. -К.: «Центр учбової літератури», 2016. $120 \mathrm{c}$.

15. Хаєцький Г.С. Екологія людини: курс лекцій для студентів географічних спеціальностей університету/ Г.С Хаєцький - Вінниця: ФОМ «Корзун» », 2014. -306 с.

\section{REFERENCES}

1. Agadzhanyan N.A. Human ecology. Selected lectures / N.A. Agadzhanyan., V. I. Torshin.- M.: Kruk, 1994.- 256 p.

2. Agadzhanyan N. A. Human ecology in the system of modern scientific knowledge and global problems of humanity / N.A. Aghazhanyan, A.E. Severin, V.I. Torshin, N. E. Aimeutava. Bulletin PFUR- Sociology .- 2002.- №1. - P. 74-94.

3. Gora E.P. Human ecology / E.P. Gora- M.: Drofa, 2007. - 540 p.

4. Gora E.P. Human ecology. Workshop /E.P. Gora- M .: Drofa, 2008. - 127 p.

5. Gubareva L.I. Human ecology: a Workshop for Universities /
L.I. Gubareva, O.M. Mizireva, T.M. Churilova - M .: VLADOS, 2005. - $112 \mathrm{p}$.

6. Dudnikova I.I.. Social and philosophical discus of human ecology / I.I. Dudnikova // Humanities bulletin of ZSEA. Philosophy. - 2009 - V.37 - P.226-233.

7. Zaletsky I.I. Human Ecology / I.I. Zaletsky, M.O. Klymenko .- K .: Publishing Center «Academy», 2005. -288 p.

8. Karmaev N.A. Modern problems of human ecology //Alienation of a person in the perspective of globalization of the world. /V.1 /Collection of philosophical articles. Edited by B.V. Markov, Y.N. Solonin, V.V.Partzvani - St. Peters- 
burg: Publishing House "Petropolis", 2001. C.87-99.

9. Kirienko T.V. Human ecology: a course of lectures for students of the natural-geographical faculty /T.V. Kirienko. Vinnitsa: PE «Printing house «Works», 2015. -176 p.

10. Nekos A.N.. Human Ecology: textbook / A.N. Nekos, L.O. Bagrova, M.O. Klymenko. - Kh.: Karazin KhNU, 2013. - 284 p.

11. Oliynyk Y.B. Fundamentals of ecology: textbook /Y.B Oliynyk, P.G. Shishchenko., O.P. Gavrilenko. - K.: Knowledge, 2012. - 558 p.

12. Plaksiyenko I.L. Some aspects of psychological follow-up of the education process at a higher education establishment / I.L. Plaksiyenko, S.N. Shupta, A.A. Kocherga // Scientific bulletin of NULES of Ukraine.- 2014.-V.199.2.-P.233-239.

13. Sitarov V.A. Social ecology: textbook for students of higher pedagogical educational institutions /V.A. Sitarov. - Moscow: publishing center "Academy", $2000-280 \mathrm{p}$.

14. Solomenko L.I. Human ecology: textbook / L.I. Solomenko $\mathrm{K}$ : "Center for educational literature", 2016-120 p.

15. Hayeletsky G.S. Human Ecology: lecture course for students of geographic specialties of the university /G. S. Khayetsky Vinnitsa: FOM "Korzun", 2014 -306 p.

\section{Some aspects of studying the personal factor in human ecology}

\section{L. Plaksiienko, P. V. Pisarenko, M. S. Samojlik, L. A. Kolesnikova}

Abstract. The studing of the ecology of the individual as a component of the academic discipline "Human Ecology" in the training of specialists in the field of ecology is consided in this article. The importance of the personal factor in the formation of the students' ecological worldview is emphasized. The use of such methodological approach positively affects the students 'mastering of fundamental theoretical knowledge in human ecology, promotes self-knowledge and provides conditions for self-realization of students' creative potential.

Keywords: human ecology, ecology of personality, self-knowledge, human adaptive potentia, ecological worldview.

\section{Некоторые аспекты изучения личностного фактора экологии человека} И. Л. Плаксиенко, П. В. Писаренко, М. С. Самойлик, Л. А. Колесникова

Аннотация. В статье обосновывается целесообразность изучения экологии личности как составляющей учебной дисциплины «Экология человека» при подготовке специалистов в области экологии, подчеркивается важность личностного фактора при формировании экологического мировоззрения студентов. Использование такого методологического подхода положительно влияет на усвоение студентами фундаментальных теоретических знаний по экологии человека, способствует самопознанию и обеспечивает условия для самореализации творческого потенциала студентов.

Ключевые слова: экология человека, экология личности, самопознание, адаптивный потенциал человека, экологическое мировоззрение. 


\title{
Advantages of using CLIL methodology in the process of future English language teachers' study in contemporary higher educational establishments of Ukraine
}

\author{
I. V. Shevchenko, O. M. Kordyuk \\ V.O. Suhkomlynsky National University of Mykolaiv, Mykolaiv, Ukraine \\ Corresponding author. E-mail: shevchenko2011@gmail.com \\ Paper received 01.06.18; Accepted for publication 09.06.18.
}

\section{https://doi.org/10.31174/SEND-PP2018-170VI70-12}

\begin{abstract}
The article is dedicated to the issues of using CLIL methodology in the process of future English language teachers' study in contemporary higher educational establishments of Ukraine. The general principles of the methodology, its advantages and disadvantages are explained. The peculiarities of planning and carrying out classes after CLIL methodology, selection of tasks and their types are pointed out.
\end{abstract}

Keywords: CLIL methodology, future English language teachers, motivation, the content of study.

Problem statement. Involving Ukrainian higher education system to the Bologna process was the beginning of its reformation and Ukrainian higher educational establishments are undergoing the complicated process of agreement of their language programs with contemporary conditions of possessing language competences. The primary purpose of both Bachelors and Masters programs is in creating professional communicative competences of students-philologists, i.e. the ability to solve communicative tasks in the frames of their professional activity. Many graduates aspire to work not only as teachers of secondary educational establishments, but also in big transnational companies, where the office language is English. Therefore, the increasing pressure of globalization changes our images of education, and good knowledge continues to provide the employment of future graduates. In this context of learning the English language with the purpose of further development of their own career is becoming extremely relevant. And the accent of learning the language is being replaced to immediacy and clearness of communication.

Decreasing class hours and giving a great amount of hours to individual study requires from teachers to reconsider the traditional methodology of learning the English language and turn to contemporary world experience.

CLIL methodology of studying foreign languages is becoming more and more widespread in the world practice.

Analysis of contemporary researches and publications. Such scholars as S.Bobil, Y. Roudnik, and others focused their attention on the problem of content and language integrated learning.

Among foreign researchers of the problem of content and language integrated learning we could point out $\mathrm{M}$. Allen, A. Bonne, D. Greddol, M.Hajer, L. Collins, D. Marsh, I. Ting and many others.

Purpose of the article. To analyze the main advantages and disadvantages of CLIL methodology in the process of future English language teachers' study in contemporary higher educational establishments of Ukraine.

Presentation of the principal material. The term CLIL was developed in 1994 by David Marsh, who was the first to describe the methodological approach according to which a foreign language is learnt in integrated way. "CLIL corresponds to situations when subjects or their parts are studied in a foreign language with a double purpose, in particular studying the content with simultaneous learning the foreign language" [7].

The purpose of "double focus" presupposes that CLIL works in two ways. Based on integrated interdisciplinary approach CLIL differs from all other approaches to language learning and studying. Many researches emphasize that CLIL methodology contributes not only to improving learners' knowledge, but also to acquiring intercultural knowledge. Contributing to the development of various teaching strategies and involving innovative methods of learning, textbooks encourage cognitive development and study in general. Besides, CLIL gives another advantage to an educational establishment, namely - a better time control [7].

In his book "Framework for Task-Based Learning" J. Willis defines tasks as an activity when a language is used by learners with communicative purpose. The result of assessment depends primarily on the result of the task, but not on the language accuracy. This makes CLIL particularly important for a learner's general development, thus breaking psychological barriers and doing away with the fear of making an error. CLIL has a worldwide support in the educational society, because it gives a great flexibility, a wide range of stimulating open tasks (thematic researches, tasks aimed at a problem solution, role-plays, exercise for listening and reading, for further discussing, presentations, negotiations, etc [10].

One of the most outstanding scholars Jon Larsson considers as one of the main advantages of CLIL reproduction of an essential improvement in learners' communicative skills and general abilities of social interrelation, that are the most important factors for a language learning [5].

Scholar Fernandes states that CLIL is a flexible method which helps to learn a foreign language. Comparing with other methods of learning, CLIL is effective, because knowledge of a particular subject provides learners with motivation for studying a foreign language.

According to CLIL methodology a foreign language is the language of instruction in educational content, that makes a language a means of learning the subject content, whereas the content makes it possible to learn a foreign language with the help of authentic communicative contexts [9]. 
According to Coyle the content of learning a foreign language concerns the knowledge of particular subject researches, such as science and arts. In CLIL context the choice of content changes in regard of a definite purpose. It is necessary to take into consideration the availability of qualified teachers, the level of those who study, their language competence and learning background. The content in learning-methodological background by CLIL method can be chosen from a traditional school curriculum, for instance physics, chemistry, mathematics, geography or even music; this can be a national curriculum or project, such as ecosystem, summit of APEC general secretary, global warming; it must also be intersectional or interdisciplinary. Thus, CLIL gives the opportunities both in frames of an ordinary curriculum and out of these frames to enrich knowledge and skills, and learners' cognitive involvement also requires being taken into account [2].

A great importance is being acquired by the activity of a teacher in defining CLIL content, as he holds the balance between learners' cognitive demand, their growth and general progress in study. Defining the content is the process of cognitive interaction, problems solution and development of creative thinking. To support effective learning using CLIL methodology learners' cognitive activity should be taken into account. Learners must be able to think individually, set new creative tasks, be interested, capable of taking the responsibility for their own construction of knowledge and management of study.

It is important to pay attention to four factors of CLIL methodology that have some similarity with other previous approaches to language learning.

The first peculiarity is naturalistic and implicit style of CLIL methodology. According to scholar Jarvinen, naturalistic and implicit style of CLIL learning should be understood as increasing possibilities for communication owing to greater focus on incoming data that a learner gets from outer environment. A great deal of information provides better results of study.

The second peculiarity of CLIL is the style of cooperative learning. While cooperative learning learners, as a rule, are divided into small groups to fulfill tasks through team work. Cooperative style of learning is effective as it gives the possibility to do away with the fear in the process of study, to stimulate learners' motivation and encourage their interaction. Autonomy of learners, created in the frames of cooperative approach to and interaction with a team member contributes to improving their communicability while learning the language.

The third peculiarity of CLIL is authenticity which allows learners to develop the capability to solve communicative problems in real life. In the course of authentic oriented learning materials are selected taking into account real language surrounding.

The fourth peculiarity of CLIL is flexibility. CLIL methodology can be used for being implemented into different curricula with different content of subject researches [4].

Despite of the fact that the notion has appeared relatively recently, the roots of integrated learning date back to distant times, beginning with early Babylonians up to the beginning of 60 s of this century, when bilingual learning acquired great popularity all over the world.
The use of a foreign language in CLIL education depends on set educational tasks and goals. CLIL combines a number of theories and approaches which are used un different educational contexts. There are several terms that describe different methods of CLIL implementation, for example full language exposure, "language flood", etc.

In defining main principles of CLIL methodological approach in different European countries they define four basic aspects which embrace cultural and language surrounding and are aimed at solving subject and educational tasks. Each of the four aspects is realized in different ways depending on the age of learners, social-linguistic background and the level of being exposed in CLIL.

The idea of using the principle of content and language integrated learning appeared as a result of growing requirements to the level of a foreign language possession in the conditions of limited hours given to its learning. Teachers almost in all countries of the world face this problem $[3,6,8]$.

This approach allows to carry out teaching in two subjects simultaneously, though a special attention can be given to language and non-language subjects.

Language learning becomes more goal-seeking as the language is used for solving definite communicative tasks. Besides, learners have the chance to become better acquainted and understand the culture of the language under study which leads to formation of learners' socialcultural competence.

A learner transmits quite a great volume of language material which is a full-scale exposure into natural language background. It is also necessary to point out the fact that the work with different topics lets study specific terms, certain language constructions, which contributes to enriching a leaner's vocabulary with content terminology and prepares him for further study and implementation of acquired knowledge and skills. Learning a foreign language and a non-language subject simultaneously is an additional means of achieving educational goals and has positive sides both for learning the foreign language and the non-language subject [4].

In our work we will consider the definition of CLIL suggested by Kochenkova O.M. In her opinion, this is a didactic methodology that allows to form in learners linguistic and communicative competences in a foreign language in the same educational context in which they undergo the formation of general knowledge and skills. [1]. Notwithstanding the advantage of the suggested methodology, its relevance and importance, the scholars point to the lack of learning materials as well as the absence of the programs of teachers' training.

A lesson that is carried out according to the methodology of content and language integrated learning must combine the following aspects:

- Taking into account a learner's knowledge and skills connected with definite elements of his professional studies.

- Using the language as a source of acquired and improved professional knowledge.

- Development of the language culture. Researches of the culture of the language under study, encouraging socialization in multicultural surrounding.

- Realizing intercultural links. 
The use of CLIL methodology in classes presupposes the involvement of four types of language activity:

- Listening comprehension which allows to speak a foreign language in professional context.

- Reading, which is the primary source of introduction new lexical units due to the use of authentic professional material.

- Writing, which improves assimilation of new material, enriches vocabulary and is the basis for development and establishment intercultural professional ties.

A teacher who plans his educational activity ought to:

- take into consideration teaching a language and developing learners' skills, avoid overloading and redundancy of terms;

- not to use excessively reading or listening to texts or extracts;

- use different tasks and exercises [1].

Goal, content, structure, purposefulness, methods and means of work according to the methodology of content and language integrated learning must reflect communicative focus of every separate lesson and the system of lessons in general. To achieve the above mentioned tasks one must follow such principles as:

1. While preparing for a lesson one should realize that this is the element of the system, consecutive step to achieving the main goal. Complex approach to planning takes into account the structure of the topic under study, unit, etc.

2. The goal of the lesson is the opening phase of projecting studies which required the achievement of diagnostic and operative tasks. It should not be too broad, one ought to take into consideration the fact that to achieve it certain time is given.

3. A learner's activity must be fruitful. New material demands involving into the learner's language practice solving different tasks, establishing links between new and already known language phenomena. Any type of the learner's activity must have personal content of fulfillment.

4. A lesson of foreign language must be built on solution of real, not imaginary tasks and problems.

5. Communicative focus of learning must be reflected in variety of organizational forms of the process of study. They help a teacher to create such situations of communication which are maximum close to real life.

6. A teacher is am equal participant of the dialogue with a leaner. The task of the teacher is not to be an outside observer, but to actually take part in the process of communication, to maximum precisely represent the real situation.

A lesson that is carried out using CLIL methodology presupposes work with text material. It is considered sensible to support texts with illustrations so that learners could visualize what they are reading. While working with authentic material learners must mark off structure markers in texts. These markers can be linguistic (headline, subtitle) and schemes, diagrams, etc. After the "basic markers" have been defined, the text structure and content can be analyzed [1].

To organize lexical material it is important to use schemes to help learners to classify ideas and the information in the text. Types of diagrams can vary for classification of groups, hierarchy, as instructions and additional information, tables that describe people and places, as well as their combinations. Structuring texts is used to make the process of learning easier and create methods aimed at developing language skills.

Learners must be able to recreate the content of the material they read in their own words. A teacher must pay attention to whether learners use the comparison of lexical units, antithesis, description, discourse markers, academic and professional vocabulary.

There is no great difference in tasks on lessons when CLIL methodology is used and ordinary lessons. There should be offered different types of exercises, taking into consideration educational goals. Such list of tasks can be offered:

- Listen to the text and make a diagram/representation/map/

graph.

- Listen to the text and fill in the table.

- Listen to the text and note certain information (dates, figures, etc)

- Listen to the text and make up a plan for it, annotation, etc.

- Listen to the text and define the stages of the process/instructions/sequence of actions.

- Listen to the text and fill in the blanks in it.

According to the CLIL methodology learners acquire knowledge of a subject from the curriculum together with simultaneous learning and using a foreign language. CLIL methodology has an advantage in solving the problem of "overloaded curriculum" as it allows to combine one or several aspects of the curriculum and increases the amount of hours for learning the language.

However, there are important factors which must be taken into account before implementing CLIL programs. They are as follows:

- available qualified teaching staff;

- the necessity of cooperation of different subject teachers;

- provision of learners with key terms and concepts in a foreign language;

- the possibility of changing schedules required for CLIL program realization (it includes time of planning academic programs).

Conclusions and proposals. So, in contemporary conditions of changing class hours for the English language learning and the necessity of training high level professional specialists for using CLIL methodology is becoming especially important. CLIL methodology that is based on integrated interdisciplinary approach contributes to acquiring intercultural knowledge, developing learners; creative thinking, forming both professional and general language competences. 


\section{REFERENCES}

1. Kochenkova O.M. Possibilities of professional training of teaching foreign languages by means of using the elements of CLIL methodology (integration of teaching a foreign language and other academic subjects)

[Electronic resource]. - Access mode: http://kochenkova.ru/publ/vozmozhnosti_profilizacii_prepoda vanija_inost

rannykh_jazykov_s_pomoshhju_primenenija_ehlementov_meto diki_clil_i ntegrirovanie_prepodavanija_inostrann/1-1-0-1

2. Coyle, D., Hood, P., \& Marsh, D. (2010). CLIL: content and language integrated learning / Coyle, D., Hood, P., \& Marsh, D. - Cambridge, UK: Cambridge University Press.European Network on Education. (2007). Key data on higher education in Europe (p. 20-60). Luxembourg, LU: Office for Official Publications of the European Communities.

3. Hajer M. Creating a language-promoting classroom: contentarea teacher sat work. In Hall, Joan Kelly and Lorrie Stoops Verplaetse (eds.) /M. Hajer, L.Maaike. - Second and foreign language learning through classroom interaction. Mahwah N.J. and London: Lawrence Erlbaum Associates. - 2000. pp. 265-285.

4. Jarvinen, H. Acquisition of English in content and language integrated learning at elementary level in the Finnish comprehensive school / H. Jarvinen. - Turku: University of Turku. -1999.

5. Larsson, Jon. Problem-Based Learning: A possible Approach to Language Education? / Jon Larsson. Polonia Institute, Jagiellonian University, 2001. - Retrieved 27 January 2013.
6. Lorenzo W. E.. Immersioneducation a l'americaine: Adescriptive study of USimmersion programs / W. E.Lorenzo, Gladstein L.A. Foreign Language Annals, 17(1) - 1984. - p.p. 3542.

7. Marsh D. Content and Language Integrated Learning: The European Dimension - Actions, Trends and Foresight Potential / D. Marsh // Retrieved December 18, 2016, [Електронний pecypc]. - Режим доступу: fromhttp://europa.eu.int/comm/education/languages/index/ht ml. - Назва з екрану.

8. Vollmer G. Helmut Johannes, Lena Heine, Randi Troschke, Debbie Coetzee, Verena Kuttel. 2006. Subject-specific competence and language use of CLIL learners: The case of geography in grade 10 of secondary schools in Germany / G. Vollmer, Helmut Johannes, Lena Heine, Randi Troschke, Debbie Coetzee, Verena Kuttel // Paper presented at the ESSE8 Conference in London, 29 August 2006. - pp.22-25

9. Wang X. "Investigating students' listening and speaking communication and perceptions through the implementation of Chinese culture content-based course." / Wang, Xingchun. - Language In India, June 2016, p. 217+. Academic OneFile, http://link.galegroup.com/apps/doc/A459894914/AONE ?u=wash89460\&sid=AONE. Accessed 30 Jan. 2018.

10. Willis, J. A. Framework for Task-Based Learning/, J. A. Willis. - Harlow. England: Pearson Longman, 1996. VanPatten, Bill; Benati, Alessandro G. Key Terms in Second Language Acquisition. London: Continuum, 2010.

Преимущества использования методики CLIL в процессе подготовки будущих учителей английского языка в высших учебных заведениях Украины

\section{И. В. Шевченко, Е. Н. Кордюк}

Аннотация. Статья посвящена проблеме использования методики CLIL в процессе подготовки будущих учителей английского языка в высших учебных заведениях Украины. Общие принцыпы методики, основные ее преимущества и недостатки объяснены. Внимание уделяется особенностям планирования и проведения уроков, используя методику CLIL, предложены здания и их виды.

Ключевые слова: методика CLIL, будущие учителя английского языка, мотивачия, содержание обучения. 


\title{
The analysis of institutional organization of science of education management as a factor of development of education research methodology
}

\author{
T. V.Sych \\ Luhansk Taras Shevchenko National University, Ukraine, Starobelsk \\ Corresponding author. E - mail: tatynasych@gmail.com
}

Paper received 12.05.18; Accepted for publication 21.05.18.

https://doi.org/10.31174/SEND-PP2018-170VI70-13

\begin{abstract}
The article presents the characteristic of institutional organization of science of management education as a factor in the development of the methodology of education management research. Academic institutions dealing with the research on education management issues; educational systems that reproduce the relevant scientific staff; state and public structures that direct scientific and pedagogical activity in this field; means of communication in this area, specialized professional scientific publications; international donor organizations and foundations that support research on education management issues are considered.
\end{abstract}

Keywords: institutionalization of science, education management, the development of theory of education management, methodology development, methodology of education management research.

Introduction. Institutionalization is an integral part of the development and differentiation of society and is considered as a process of the emergence and formation of social institutions - the key structural elements of society. One of such social institution is science, which provides the production of knowledge accumulation, as well as their use in practice. The institutionalization of science reflects the current tendency towards the differentiation of scientific knowledge as an important factor in the development of pedagogical science, the formation of new scientific theories, the specialization of scientific disciplines, in particular the theory of education management. The functional purpose of institutes of organization of education management science is implementation regulatory, integration, communicative processes and recreation scientific personnel in the field of education management [2]. According to the results of the analysis of the formation of institutes of science management education, we can draw the conclusions about the development of the methodology of education management research. The effect of certain methodological norms on the implementation and scientific research publication in this field, the mechanisms for the formation of scientific problems and the protection of dissertation research testify these conclusions.

Brief review of publications on the topic. Some aspects of institutionalization of science in education management are considered in the works of O. Adamenko, N. Vasiniova, V. Kurilo, V. Lunyachek, V. Ponomarenko, I. Teleshova, E. Khrykova, S. Yablochnikova and others. The issue of the training of education managers was rewied by E. Bereznyak, V. Bondar, T. Borova, Y. Vasiliev, B. Gershunsky, V. Goromovyi, G. Yelnikov, A. Ermola, I. Zhernosek, O. Zaichenko, O. Kasyanova, S. Klepko, N. Klokar, V. Kremen, V. Lazarev, V. Lugovyi, T. Lukina, A. Marmaza, V. Maslov, V. Oliynyk, L. Parashchenko, G. Polyakova, M. Portnov, M. Potashnik et al., institutionalization in the aspect of the development of different parts of the system of education is considered in the rites of V. Andrushchenko, I. Gancherenok, Z. Zhukovska, L. Kvasova, V. Frolov, V. Senashenko, O. Sidorenko, T.V. Topchii (continuing education in Ukraine); V. Andrushchenko, O. Antonova, S. Vitvitska, L. Gorbunova, M. Zubrytska, K. Korsak, M. Kultaeva, S. Kurbatova, N. Myronchuk, N. Sydorchuk (higher education in Ukraine) and others. So E. Khrykov determines institutionalization among the criteria of the development of pedagogical science, which is demonstrated by the creation of the Academy of Pedagogical Sciences, the system of research institutes, specialized councils for the defence of dissertations, periodical professional publications [8]. In our opinion, this is not a complete list of indicators of the institutional organization of science education management. $\mathrm{N}$. Vasyniova establishes the criterion "Institutional design of the scientific field" in her study of the development of theory of management of higher education. She notes that any period of the development of theory of higher educational institutions management is characterized by the presence of prominent scholars, science schools and centers, whose activities had a decisive influence on the development of pedagogical thought and the development of management theory of higher educational institutions in Ukraine; the change of organizational forms of science, as well as the inclusion of new historical and pedagogical sources in the scientific circulation; the formation of a school of science (or schools), whose scope would include studying the theory of management of higher education institutions in Ukraine [1]. V. Kurilo considered the development of the system of scientific and pedagogical communication, the nature of scientific production, and the range of scholar in his study "Formation and development of the system of education and pedagogical thought of the East Ukrainian region in the twentieth century" [5], However, a complex study of the institutional organization of science in education management in Ukraine was not implemented.

The purpose of the article is a description of the institutional organization of education management science as a factor in the development of the methodology of education management research.

Materials and methods. Different forms of institutionalization of education management have been analyzed. The analysis of educational institutions that deal with education management training and scholars that develop education management issues have been carried out. The institutions that regulate, support, and carry out research on education management issues have been investigated. Repository of the V.I. Vernadsky National Library of Ukraine has been studied for availability of periodicals on the problems of education management. The protocols of approval of the topics of the dissertation research specialty 13.00 .06 - "Theory and methods of education management" for the period from 2008 to 2018 have been analyzed on the website of the Interdepartmental 
Council for the Coordination of Researches in the field of Education, Pedagogy and Psychology, which is at the National Academy of Pedagogical Sciences. We have studied the sites of specialized academic councils of the University of Education Management of the National Academy of Sciences of Ukraine, Luhansk Shevchenko National University, Cherkasy Khmelnitsky National University where the doctoral and candidate's theses are defended in the specialty 13.00.06 - "Theory and methodology of education management". The dynamics of the number of protected topics in this specialty for the period from 2008 to 2018 in relation to the approved topics have been analyzed.

The results and their discussion. As a result of the analysis of scientific literature, which covers this issue, we have identified the following forms of institutionalization of science in the field of education management: academic institutions that deal with research on education management issues (research centers, research institutes, etc.); educational systems that reproduce the relevant scientific staff (universities, institutes); state structures that direct scientific and pedagogical activities in this field (information and analytical centers, advisory councils, specialized councils for the defense of dissertations); public organizations that deal with education management issues (academies, associations, consortia, unions); permanent workshops and periodic conferences, symposiums, working meetings on the issues of education management; specialized professional scientific publications; international donor organizations and foundations that support research on education management issues.

The consideration of the availability of academic institutions involved in the study of education management issues provided the following results. The academic level of research on education management issues is usually carried out by university departments, primarily at national pedagogical universities. Among the academic institutions that study problems of education management, the undisputed leadership belongs to the Academy of Pedagogical Sciences of Ukraine (APSU of Ukraine). This "highest state scientific institution" was established in 1992. Among the network of institutes under the APS of Ukraine, the special role in the study of education management issues belongs to the institutes of pedagogy, pedagogical education and adult education, the Central Institute of Postgraduate Education and its affiliates, the Institute of Higher Education, the University of Management Education [6]. Specialized research institutions that deal exclusively with research on education management issues in Ukraine are absent.

An integral part of the process of institutionalization is the formation of a scientific community that studies issues of education management. First and foremost, this is the training of scientific staff on the basis of higher education institutions. In due time, the University of Management of Education of the National Academy of Pedagogical Sciences of Ukraine and Taras Shevchenko Luhansk National University became the peculiar "forge" of education management personnel. It was at these institutions that specialized scientific councils for defence of doctoral and candidate's theses were stated at the specialty 13.00.06 - "Theory and methodology of education management". At the end of 2013, a specialized academic council for the defense of theses was created on the specialty 13.00.06 at the Bohdan Khmelnytsky National University of Cherkasy. However, the geography of the implementation of scientific and pedagogical research in this area extends beyond these scientific centers, it is much wider. These are actually all the regions of our state from Uzhgorod to Luhansk. It should be noted that for quite a long time the indicated direction of training was absent in the classifier of scientific specialties. Only in September 2006, by the Resolution No. 6-06 / 8 of the Presidium of the Higher Attestation Commission of Ukraine, the name of the specialty 13.00.06 was approved in the new wording and the constituent contents of its passport (classification characteristics, research directions, etc.). In accordance with the Resolution of the Cabinet of Ministers of Ukraine "On Approval of the List of Fields of Knowledge and Specialties under which Higher Education Recipients are Prepared" dated April 29, 2015, No. 266, specialty 13.00 .06 - "Theory and Methodology of Education Management" corresponds to the specialty 011 Educational, Pedagogical science, specialization "Theory and methodology of education management".

The first theses for obtaining a scientific degree of a candidate of pedagogical sciences in specialty 13.00.06 were presented for defense in 2008. Their protection took place in the specialized boards of the University of Management of Education of the National Academy of Sciences of Ukraine (A. Guralyuk, N. Popova, O.Bodnar, N.Murovana) and Lugansk Shevchenko National University (S. Burdina). The first scientific research at the qualification level of the Doctor of Sciences in Management of Education was defended in 2008 at the specialized academic council of the University of Management of Education of the National Academy of Sciences of Ukraine. This was a doctoral dissertation by L.Kalinina "The Information Management System for a General Educational Institution". In general, from June 2008 to December 2017, 127 scholars and educators defended dissertations in specialty 13.00.06 - Theory and Methods of Education Management and received appropriate confirmation from the Attestation Board of the Ministry of Education and Science of Ukraine, thirty of which were doctoral. According to the analysis of the protocols of the interdepartmental council for the coordination of scientific research at the National Academy of Sciences of Ukraine for the period, 72 topics of doctoral dissertation researches and 233 themes of candidate dissertation researches were approved, which together make up 305 topics. This is despite the fact that the problem of education management is also under the cipher of other specialties.

It should be noted that the theory of education management has developed for a long time as a component of pedagogical theory. Selection of specialty 13.00.06 shows the differentiation of pedagogical knowledge. The process of differentiation of scientific knowledge corresponds to the division of labor, specialization in pedagogical and scientific activities. Differentiation finds its embodiment in the system of professional training, advanced training, training of scientific personnel. As Ye.Hrykov notes, the concept of "differentiation" characterizes the structuring of scientific knowledge, scientific disciplines, and the concept of "specialization" characterizes the division of scientific work, its deepening in connection with the complication of educational processes and scientific activity. Among the immediate causes of branch specialization, he highlights the role and complexity of a certain aspect of educational activity, the specialization of types of pedagogical activities, the accumulation of a considerable amount of information on this 
aspect of educational activity, creating more favorable conditions for deepening scientific research [7].

According to its name and logic, the specialty 13.00 .06 should provide the study of managerial problems of all components of education, but the study of managerial problems include passports of other specialties. As Ye.Hrykov notes, the lack of elaboration of the research methodology peculiarities in certain specialties, the lack of research topics in the specialty on the development of methodology - is a major factor in casting doubt on the need to identify a particular specialty and characterizes its initial level of development [7]. However, in the passport of specialty 13.00.06, the directions of research on solving methodological problems are determined, which indicates the attention to this problem. But the analysis of the approved research topic showed that only one of them comprehensively considers this problem, namely the dissertation research of the author of the article "Development of research methodology of education management in the history of native pedagogical science (second half of the XX - the beginning of the XXI century)".

Comparing the number of approved topics in the specialty 13.00.06 allows us to conclude that by 2005 their average number is more than 30 , but in 2017 only 16 topics were approved (Fig. 1).

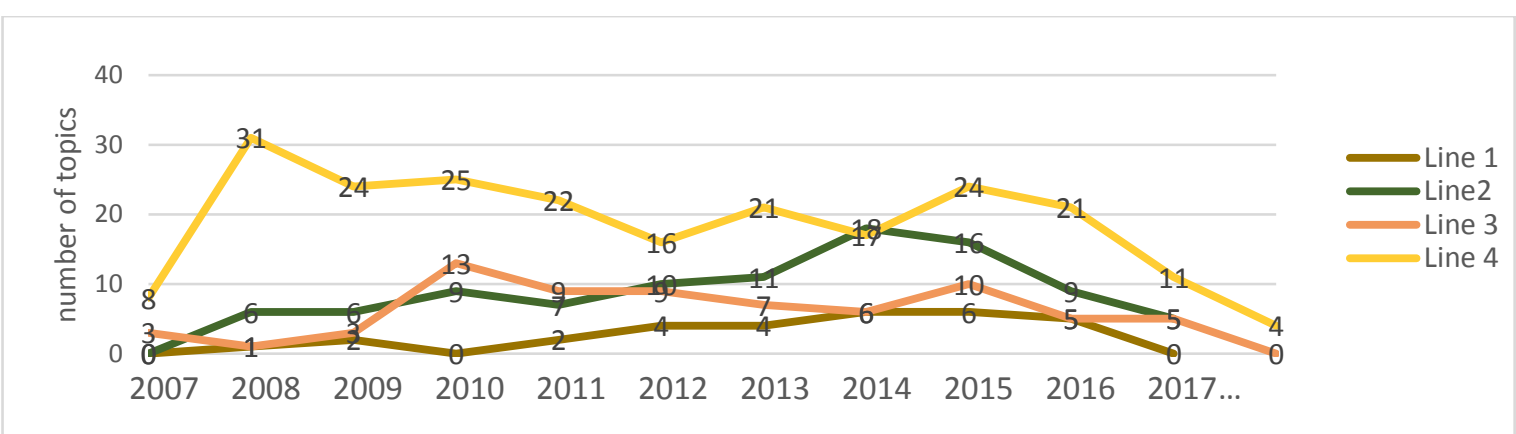

Fig. 1. The analysis of the number of approved and protected topics of the dissertation works in the specialty "Theory and methods of education management"

Line 1 - Protected topics of doctoral theses

Line 2 - Protected topics of $\mathrm{PhD}$ theses

Line 3 - Approved topics of doctoral theses

Line 4 - Approved topics of $\mathrm{PhD}$ theses

This is not indicates waning interest in education management . In our opinion, the decrease in the number of approved topics reflects the general tendency in other specialties. The reasons for this phenomenon can be found in the crisis situation in the country, in the reduced funding research budget, more difficult requirements for the award of scientific degrees, etc. Concidering the ratio of protected topics to the approved is $42 \%$, in a few years there will be few scientists who are investigating the problems of education management in our country. The largest number of protected works in this specialty is observed in 2012-2015. (from 14 in 2012 to 24 in 2015 with a gradual increase). In 2014 there are 14 works, and in 2017, only 5 candidate's theses and no doctorate in the specialization "Theory and Methods of Education Management." Indeed, a large number of theses do not always indicate the development of science, but reflects the number of scientists who are investigating a certain scientific problem area. The quality of research depends on the methodology of their implementation and the availability of regulatory requirements as for the evidence of the results of the study.

Also, the basis for the development of scientific ground in this specialty was the establishment of a master's degree in the field of "Management of an educational institution" in the 90s years of the 20th century on the basis of national universities. The first university in which such a magistracy was opened is Luhansk Shevchenko National University. Training the leading personnel for the sphere of education management and masters in this specialty started at the Kharkiv National Pedagogical University named after G.S. Skovoroda (KHNPU), the Ukrainian Engineering Pedagogical Academy (UIPA), RVNZ "Crimean Humanitarian University ", Sumy State Pedagogical University named after A. S. Makarenko
(SDPU). These establishments were the first in this sphere.[4]. At present, such training is being conducted in more than 25 pedagogical institutions of higher education in Ukraine and in 6 non-pedagogical universities [3]. The history of training the heads of education in the field of "Management of educational institutions" has been in Ukraine for more than twenty years, and in the vast majority of pedagogical universities it is less than 10 years. We agree with V. Lunyachek, who insists on the need for a normative definition of the compulsory level of education for applicants for management positions in the education system of Ukraine. It should be the qualification of a master's degree in the field of "Management of an educational institution", considering the requirements of the present stage of education development and potential possibility of higher education institutions in Ukraine. The education system should be provided by the relevant specialists [4].

An analysis of the development of communicative processes has shown that there are enough scientific and scientific-practical conferences and seminars of different levels, the topics of which are correlated with managerial issues in the field of education in Ukraine and abroad, but the theory of education management continues to develop within pedagogy. So, the publication of articles by scientists is usually carried out in pedagogical editions, newsletters of universities, as well as in periodicals on public administration and even in economic and psychological periodicals. Nowadays, there are two periodicals on the management of education in Ukraine. This is a scientific and practical journal published by the Academy of Sciences of the Higher School of Ukraine, the Ukrainian-American Humanitarian Institute "Wisconsin. International University (USA) in Ukraine" since 1996, namely:" Education and Management". Since 2008, the 
University of Management Education of the National Academy of Pedagogical Sciences of Ukraine issued an electronic scientific specialty magazine "Theory and Methods of Education Management". So the publication of the first periodical specialized magazine is connected with the period when, after isolation in Soviet times, relations with foreign educational institutions were established, the domestic scientific community got access to the achievements of Western management theory. The launch of the second specialized edition coincides with the time of protection of the first theses in the specialty 13.00.06. Since its publication was based on the University of Management Education of the National Academy of Pedagogical Sciences of Ukraine, where a specialized academic council on the defence of theses on this specialty worked at that time, the publication was triggered by the emergence of a new specialty.

With regard to international donor organizations and foundations supporting research, it can be noted that in Ukraine, this manifestation of institutionalization only develops. This will be facilitated by the introduction of grant funding through the National Research Foundation, whose creation is planned in 2018. It is planned that the fund will support, conducting both fundamental and applied researches, internships of scientists abroad, holding important international conferences. Its regulatory function will be implemented according to world standards of transparent distribution of finance and the quality of conducting scientific expertise and selection of bids. To date, Ukraine has launched the EU grant program on research and innovation "Horizon 2020", which is designed for seven years from 2014 to 2020.

Besides, public mechanisms of education and science management in Ukraine are on their way. In 2013, the State
"Association of Management Problems Researchers " was founded and registered on the basis of the "Lugansk Shevchenko National University". In 2015, the Public Organisation «Ukrainian Educational Research Association» (UERA) was created and registered as a voluntary nonprofit non-governmental organization based on the Ivan Franko Drohobych State Pedagogical University. On March 18, 2017 , UERA gained the status of a full member of the European Association of Educational Researchers (EERA). In Odessa, the "Association of Researchers in Public Administration" has been registered. The development of public native structures of science management, activating their activities and gaining authority among scientists, both domestic and foreign, can become an important factor in the development of scientific theory and research methodology.

Conclusions. Consequently, the analysis showed that the scientific theory of education management has its institutes for the reproduction of scientific staff, specialized councils for the defence of dissertations, communication channels for exchanging scientific information, specialized periodicals. The public education management is at the stage of formation. All these institutions are important factors in the development of research methodology in this branch of science. However, there are no specialized research institutions in the field of research on education management issues in Ukraine; the number of scientists developing this issue has decreased significantly during the last year, and the number of defended dissertations has decreased. These negative trends should be studied in order to develop effective mechanisms for managing the development of education management theories and conducting research in this area.

\title{
REFERENCES
}

1. Vasyniova N.S. Substantiation of criteria for analysis and evaluation of the development of the theory of management of higher educational institutions in Ukraine (the last quarter of the $\mathrm{XX}$ - the beginning of the XXI century) // Creation of a quality management system for administrative, social and educational services: theory and practice: materials of sciences. conf. (April 18, 2013, Luhansk): in 2 v./Ed.board: O.M. Klimochkina, Ye. Khrykov, O.Kravchenko - Lugansk: PH "LNU named after Taras Shevchenko", 2013. - v.2.

2. Gerasymchuk, Andriy Andriyovych Sociology: Textbook /A.A. Gerasymchuk, Yu.I. Paleha, O.M. Shyan; European Univ. - K.: Publishing House of the European Union, 2004. - 246 p. : tabl.

3. Information system "Competition" [E. resource]. - Access mode: http://www.vstup.info/2012/i2012okr2bf939e623-b30f4b43a9be5dbefb8dab5e.html

4. Lunyachek V. Some questions of establishment a specialty "Management of an educational institution"//Problems of modern

pedagogical education. Pedagogy and psychology. - 2013. - Issue 38 (2). - P. 264-271.

5. Methodological foundations of pedagogical research: monograph/Ye. Khrykov, A. Adamenko, V. Kurilo and others; Ed. V. Kurilo, Ye. Khrykov. - Luhansk: PH "LNU named after Taras Shevchenko", 2013. -248 p.

6. Ponomarenko V. Institutionalization of Research and Analysis of Educational Policy as an Interdisciplinary Direction//Ukrainian Scientific Journal "Education of the Region: Political Science, Psychology, Communication" No. 2 - 2010 - [E. resource] Access mode: http://social-science.com.ua/article/254

7. Hrykov Ye. Branch Specialization in Pedagogical Science // Ukrainian Pedagogical Journal. - Kyiv: NAPS of Ukraine. 2018. №1. - p. 38-46.

8. Hrykov Ye. Methodology of pedagogical research: monograph / Ye. Khrykov. - Kharkiv: FOP Panov A.M., 2017. - 237 p.

\begin{abstract}
Анализ институциональной организации науки управления образованием как фактора развития методологии исследования образования

Т. В. Сыч

Аннотация. В статье представлена характеристика институциональной организации науки управления образованием как фактора развития методологии исследования проблем управления образованием. Рассмотрены академические учреждения, занимающиеся исследованием проблем управления образованием; образовательные системы, которые воспроизводят соответствующие научные кадры; государственные и общественные структуры, которые направляют научно-педагогическую деятельность в этой отрасли; средства коммуникации в этой сфере, специализированные профессиональные научные издания; международные донорские организации и фонды, которые поддерживают исследования проблем управления образованием.
\end{abstract}

Ключевые слова: институционализация науки, управление образованием, развитие теории управления образованием, развитие методологии, методология исследования проблем управления образованием. 


\title{
Особенности обучения географии старшеклассников на профильном уровне в современной украинской школе
}

\author{
И. В. Удовиченко
}

Сумской областной институт последипломного педагогического образования, г. Сумы, Украина

Paper received 01.06.18; Accepted for publication 09.06.18.

\section{https://doi.org/10.31174/SEND-PP2018-170VI70-14}

\begin{abstract}
Аннотация. Статья посвящена вопросу рассмотрения современных условий обучения старшеклассников общеобразовательных учебных заведений нового типа, как переходного периода к географическому профильному преподаванию в Украине. Проанализированы тенденции структурных, содержательных, организационных изменений в обучении географии на общеобразовательном уровне в украинских школах, в связи с происходящими современными реформационными процессами. Акцентировано внимание на значимости формирования гражданской компетентности выпускникив старшей школы на уроках географии в контексте реализации идей компетентностно-ориентированного обучения.
\end{abstract}

Ключевые слова: география, ученики стариих классов, средние общеобразовательные учебные заведения, профильное обучение, новая украинская школа, гражданская компетентность.

Постановка проблемы. Направленность ситемы образования Украины на усвоение суммы знаний, которая была традиционной и оправданной ещё несколько десятилетий тому назад, уже не отвечает современному социальному заказу, что, в свою очередь, требует воспитания самостоятельных, инициативных, ответственных членов общества, способных эффективно взаимодействовать в решении социальных, гражданских, производственных задач.

Как свидетельствует теория и практика, в условиях информационного общества, необходимым есть смещение акцентов в школьном обучении с принципа колличественной адаптивности на качественную компетентность выпускников средних общеобразовательных заведений вообще и профильного направления в частности.

Существенные возможности открывает перед учеником профильное среднее общеобразовательное заведение, структура и образовательный процес в котором позволяют реализовать идеи компетентностноориентированного обучения, развивать у выпускника определённые умения и навыки, в частности: быть мобильным и конкуретноспособным, уметь интегрироваться в динамическое общество, презентовать себя на рынке труда; использовать знания как инструмент для решения жизненных задач и проблем; генерировать новые идеи, принимать нестандартные решения и нести за них ответсвтенность; обладать комуникативной культурой, уметь работать в команде; уметь предусматривать и достойно выходить из различных конфликтных ситуаций; целенаправленно использовать свой умственный потенциал как для самореализации в профессиональном и личном плане, так и в интересах общества, государства, коллектива; уметь самостоятельно находить, анализировать информацию, полученную из различных источников, использовать её для индивидуального развития и самоусовершенствования; бережно относится к своей жизни и здоровью, а также других граждан, как к наивысшей ценности; быть способным к выбору многочисленных альтернатив, которые предлагает современная жизнь.

Всё перечисленное выше характерно для компетентной личности, а овладение жизненно важными компетенциями позволяет человеку еффективно ориентироваться в современном динамичном мире, быстро реагировать на запросы времени, в этой связи социальные и педагогические проблемы формирования компетентной личности выходят на уровень преоритетных в современном украинском обществе [5].
Анализ последних исследований и публикаций. Сегодня компетентностный подход - предмет изучения многих учёных и практиков. Этой проблеме посвящены труды украинских и зарубежных исследователей, а именно: Н. Бибик, И. Беха, Л. Боголюбова, В. Болотовой, И. Зимней, О. Бондаревской, Т. Волобуевой, Т. Вороновой, И. Жадана, Н. Калининой, В. Киричук, В. Краевского, А. Крысана, А. Овчарук, А. Пометун, Дж. Равена, Б. Рея, С. Рябова, А. Савченко, В. Серикова, Л. Сохань, А. Сухомлинской и многих других.

Особенности обучения географии в школах Украины рассматривали: В. Корнееев, Н. Мунич, А. Надтока, Т. Назарова, Е. Павлюченков, О. Топузов, П. Шищенко и многие другие.

Пути формирования гражданской компетентности учеников в школе проанализировано в трудах В. Болотова, Н. Лесовой, А. Пометун, И. Сигова, О. Смирновой, Э. Слабуновой, В. Стрельникова и других.

Формулирование цели статьи. Целью статьи есть рассмотрение специфики современного обучения старшеклассников на уроках географии в средних общеобразовательных заведениях Украины профильного направления, в контексте компетентностного подхода к изложению учебного материала и соответственно требований к построению новой украинской школы.

Методы исследования. С целью рассмотрения вопроса особенностей обучения географии старшеклассников на профильном уровне в современной украинской школе, использовано методы: анализа, синтеза, сравнения, умозаключения, обобщения и другие.

Изложение основного материала. Формирование гражданской компетентности в учеников - важная составная становления гражданского общества в Украине, что, в свою очередь, предусматривает трансформацию мировоззренческих ориентаций и самосознания людей, а также структурных изменений общеобразовательного процесса в школе, особенно в современном переходном периоде, когда обучение организовано на уровнях: стандарта, академическом, профильном. Требованием же времени есть - полноформатное функционирование профильных учебных заведений с соответствующим предоставлением образовательных услуг (курсы по выбору, альтернативные программы, учебники и многое другое) в Украине.

По нашему мнению, актуальным есть смещение акцента в обучении географии старшекласников в школе, а особенно профильной, с приобретения суммы знаний, умений на формирование практических навыков действовать, 
используя опыт успешных действий, с помощью использования компетентносно-ориентированного подхода.

Проведённый нами обзор научно-популярной, информационно-методической литературы, позволяет констатировать недостаточную разработку теоретических и практических составных процесса формирования различных компетентностей в учеников на уроках географии, особенно в контексте новых реформационных изменений, которые касаються содержательных, организационных, структурных составных.

Как показывает проведённый нами анализ, содержание современного школьного образования в Украине не в полной мере отвечает требованиям современного общества и рынка труда, а, значит, не всегда направлено на формирование необходимых жизненных компетентностей. Школа сегодня недостаточно обучает школьников принимать самостоятельные решения, использовать информационно-комуникационные технологии, критически мыслить, творчески решать проблемные вопросы и нестандартно моделировать ситуации.

Формирование в среднем общеобразовательном заведении в учеников готовности ко взрослой самостоятельной жизни, способности ориентироваться в современном обществе, адекватно реагировать на все его современные вызовы и требования времени, эффективно и успешно самореализоваться во взрослой жизни - требования к гражданской компетентности школьников [3].

Анализ такого нормативного документа, как Государственный стандарт базового и полного среднего образования (утверждён Постановлением Кабинета Министров Украины от 23.11.2011 № 1392), а также учебных программ современной школы Украины по различным предметам позволил нам сделать вывод, что вопрос формирования гражданской компетентности учеников целесооборазно осуществлять комплексно, с помощью интегрованых курсов, профильного обучения [2].

В частности, в Государственном стандарте базового и полного среднего образования подана трактовка таких понятий, как «компетентность» (приобретённая в процессе обучения интегрированная способность ученика, которая состоит из знаний, умений, опыта, ценностей, отношений, которые могут быть реализованы на практике), «ключевая компетентность» (специально структуриванный комплекс характеристик (качеств) личности, что даёт возможность ей эффективно действовать в различных сферах жизнедеятельности и принадлежит к общеотраслевому содержанию образовательных стандартов), «компетентностный подход» (направленность образовательного подхода на достижение результатов, какими есть иерархично соподчинённые ключевая, общепредметная, предметная компетентности) [2].

Актуальность внедрения в образовательную практику компетентностного подхода обусловлено совокупностью причин: внешних (стремительное социальное, технологическое, политическое развитие мира) и внутренних (кризиса парадигмы знаний в образовании) [1].

На современном этапе развития украинского общества гражданское воспитание есть важной составной общеобразовательного процесса в среднем учебном заведении. Это - сложный и многоаспектный процесс, который требует системного, систематического преобретения общественно-исторических, природно-географических, финансово-экономических, научно-практических умений, навыков, компетенций.

Формирование компетентного выпускника на сегод- няшный день - одна из актуальных проблем образования и рассматривается как выход из проблемной ситуации, что возникла в связи с противоречием между необходимостью обеспечить качественное образование и невозможностью решить эту проблему традиционным путём.

Проведённый нами анализ школьной практики в Украине, позволяет утверждать, что современное образование всего лишь частично направлено на ситемную работу по формированию гражданской компетентности выпускников, а основной акцент в обучении сделано на формирование в учеников общих умений и навыков.

Наше исследование базируется на утверждении, что формирование гражданской компетентности личности ученика в процессе обучения географии будет эффективным в профильном учебном заведении, где: гражданская компетентность рассматривается как один из важных результатов процесса обучения в старшей школе; в содержании учебного географического материала сделан акцент на формирование гражданских ценностей и соответствующих социально-экономических географических знаний, умений, навыков; учебный процесс смоделирован под углом зрения интегрированного, компетентностно-ориентированного обучения.

В сегодняшнем переходном этапе реформирования системы образования в Украине у современного учителя расширены права в пунктах свободы разработки авторских програм, учебных пособий, учебников, дидактических комплексов; построения учебных и календарнотематических планов, а в современной школе идеи гражданского воспитания органически вписываются в содержание и методику урочной и вне урочной работы в профильной школе, организацию жизнедеятельности школьников. Это направление воспитания на уроках географии ставит перед собой цели - формирование в учеников знаний и представлений про современное украинское общество, родной край, экономическое состояние государства.

Географические знания - основа воспитания в учеников любви к родному краю, осознаного гражданства, патриотизма, качеств бережливого и ответственного хозяйственника, так как всё это характеризует наилучшие личностные и гражданские ценности человека, как личности.

Под гражданской компетентностью нами понимается способность человека ответственно, эффективно реализовать свои гражданские права и обязанности, с целью активного участия в развитии гражданского общества, процессов принятия решений, контроля за ними.

Географическая составная играет важную роль в процессе формирования гражданской компетентности выпускника школы. Особенное внимание тут акцентируется на геопространственном мышлении, сущности економических, екологических, социальных проблем общества, умении осознано ориентироваться в социально-экономических, общественно-политических, геоекологических процессах в Украине и этому, в значительной степени способствуют интегрированные уроки в профильной школе, во время которых комплексно рассматримаются все перечисленные выше вопросы [4].

Целенаправленное формирование гражданской компетентности учеников в школе предусматривает реализацию в образовании компетенстно-ориентированного подхода к изложению и воспроизведению учебного материала вообще, а на уроках географии в частности. 
Одним из путей решения этой проблемы есть рассмотрение географических вопросов под углом зрения гражданского восприятия, чему способствуют приведённые ниже примеры тематических заданий:

- укажите, где в хозяйстенной деятельности и с какаой целью воду рек может использовать человек, к каким экологическим последствиям это может привести, доказав безопастность купания в таких реках и то, как общество может решить элогическиепроблемы малых рек;

- назовите, в каких районах земного шара образовываються гейзеры и как в хозяйственной деятельности можна использовать их воду, подумав, как они влияют на экологическое состояние, улучшения благосостояния и здоровья населения, предложив пути эффективного использования гарячей воды гейзеров напользучеловека;

- назовите основные причины образования болот, докажите их пользу (вред) для окружающей среды, екологического состояния, здоровья людей и то, к каким последствиям может привести осушивание болот, предложив пути их использования в хозяйственной деятельности человека вообще и Украине в частности.

По нашему мнению, детальному рассмотрению тематических вопросов на уроках географии способствует именно профильное обучение, когда изучению определённой проблемы отводится значительное учебное время и таким образом смоделированное исследование проходит под углом зрения четырёх содержательных линий: экологическая безопастность и стабильное развитие, предпринимательство и финансовая грамотность, здоровье и безопастность, гражданская ответственность.

Подготовка всесторонне грамотного и осведомлённого гражданина к активному участию в жизни общества, формирование гражданской компетентности подростающего поколения - необходимые составные развития демократического общества в Украине.

Проблема гражданского воспитания школьников находится в центре внимания учителей географии, которые направляют подростающеее поколение на осознаный выбор профессии, гражданских ценностей, мотивируя к самоусовершенствованию, готовности полноценно жить в гражданском обществе, частью которого они есть, самостоятельности принятия решений, которые касаются различных сфер жизнедеятельности (производство, политика, образование, искусство, медицина, досуг, религия и многое другое).

Всё это позволяет утверждать, что компоненты гражданской компетентности могут быть эффективно сформироваными в учеников на уроках географии в старшей школе, особенно профильной, где углублённо рассматривается учебные темы и проблемные вопросы, прежде всего те, что в большей мере связаны с геополитическим, социально-экономическим положением, комплексным рассмотрением географических проблем.

Выводы. Современная молодёж нуждается в приобретении готовности к жини в открытом эвропейском обществе, формировании социальной активности игражданской компетентности, осознании своей роли в жизни общества и убеждённости в том, что они могут положительно влиять на происходящие вокруг них общественные процессы.

Отсюда, - подготовка компетентного выпускника это реализация высокой гуманистической миссии среднего образования, так как школа не только место, где приобретают знания, умения и навыки, а где развивается и преумножается жизненный потенциал личности, формируется компетентность, индивидуально-личностная траектория жизнетворчества.

Компетентный выпускник способен сохранить, раскрыть, развить, конструктивно реализовать свой жизненный и жизнетворческий потенциал в условиях сложных условий, требований, рисков, которые перед ним выдвигает современность [1].

Обеспечить развитие гражданской компетенции, сформировать гражданскую компетентность, привить гражданские ценности и ориентиры личности, а также сформировать соответствующие знания, умения и навыки по гражданскому образованию в профильной школе - призваны сегодня учебные предметы вообще, а география в частности.

[1] Болотов В. А. Компетентностная модель : от идеи к образовательной программе / В. А. Болотов, В. В. Сериков // Педагогика. - 2003. - № 10. - С. 8-14.

[2] Державні стандарти базової і повної середньої освіти // Урядовий кур'єр. - 2012. - № 19. - С. 5.

[3] Забезпечення формування громадянської компетентності у сучасному змісті шкільної освіти. Підсумковий документ робочої групи з розробки планів і програм проекту «Грома-

\section{REFERENCES}

[1] Bolotov V. A. Kompetentnostnay model : ot idei k obrazovatelnou programme / V. A. Bolotov, V. V. Serikov // Pedagogika. 2003. - № 10. - S. 8-14.

[2] Derchavni standartu bazovoi i povnoi serednoi osvitu // Yradovuy kyrer. -2012 . - № 19. - S. 5 .

[3] Zabezpechenna formyvanna gromadanskoi kompetentnosti y suchasnomy zmisti chkilnoi osvitu. Pidsymkovuy dokyment robo-

choi grypu z rozrobku planiv i program proekty «Gromadanska osvita-Ukraina»//Istoria v chkolach Ukrainu.-2006.-№8.-S.3-5.

[4] Korneev V. P. Technologii v navchanni geografii / V. P. Korneev. - Ch. : Osnova, 2004. $-74 \mathrm{~s}$.

[5] Ovcharyk O. V. Kompetentnisnuy pidchid u suchasniy osviti : svitovuy dosvid ta ukrainski perspektuvu / O. V. Ovcharyk. - K. : K.I.S., 2004. - 112 s.

\section{Peculiarities of teaching geography to high school graduates at profile level in modern Ukrainian school}

\section{V. Udovychenko}

Abstract. The article is devoted to the consideration of modern terms of high school graduates teaching in general educational establishments of a new type, as a transition period to geographic profile teaching in Ukraine. The author analyzes the trends of structural, content, organizational changes in geography teaching at general educational level in Ukrainian schools, in connection with modern reform processes. Attention is focused on the importance of forming of civil competence of a graduate of a high school at geography lessons in the context of implementing ideas of competence-oriented learning.

Keywords: geography, graduates, general educational establishments, profile teaching, new Ukrainian school, civil competence. 


\title{
Methodological complexity in the study of consciousness
}

\author{
K. Zobenko \\ Department of Philosophy and Methodology of knowledge Mechnikova I.I. National University (Odessa, Ukraine) \\ Corresponding author. Email: zobenko.kseniya106@gmail.com \\ Paper received 05.05.18; Accepted for publication 13.05.18.
}

\section{https://doi.org/10.31174/SEND-PP2018-170VI70-15}

\begin{abstract}
Why are we conscious? How can it be that information processed in the human brain is accompanied by subjective experience? An integral part of the problem of consciousness is the methodology of its solution. A lot of different methods in the study of consciousness, the author define as a convergence of the basic properties of consciousness in connection with the change in the methodological characteristics of research programs. Methodological pluralism, characteristic for modern philosophy of consciousness, is manifested, first of all, as a set of research strategies for solving the problem of consciousness and their interpretations.
\end{abstract}

Keywords: consciousness, methodology, pluralism, philosophical attitude, reflection, approaches.

Introduction. The study of human cognition has always been one of the main tasks of philosophy. In conditions of the development of experimental and mathematical science in science, a steady practice of applying natural-science research methods to traditional objects of philosophy is fixed; here I single out consciousness as a way of knowing the world by man. In the era of modernity there is an intensive differentiation of sciences, in the conditions of which the specificity of cognition and human consciousness are studied not only in the field of humanities, social sciences, philosophy, but also in the field of technical and computer disciplines: neurophysiology, neuroinformatics, and artificial intelligence. Achievements of the XX-XXI centuries in the conditions of scientific and technological progress had a colossal influence on the present, whereby the modern world is overflowed with artificial objects (artifacts), which have practically replaced natural objects. Technological transformations uniquely provoke social changes in society. Modern man is in the reality of the digital environment.

Paradoxically, and thus the complexity of this reality lies in the questions: 1. the digital environment simply belongs to the present, while being only one of its dimensions? 2. Or does the digital environment determine the life of a modern person? For natural objects it is characteristic that the process of their reproduction and functioning is completely independent of human existence and human activity, but the existence and functioning of artificial objects directly depends on this. And as applied to the problem of consciousness, one can observe tendencies of the convergence of the "natural" and "artificial" in understanding its nature. Modern technologies overcome the binary ontology of "natural" and "artificial". The study of the nature of consciousness in the modern world has become unthinkable without analogies with artifacts, virtualistics, and problems of artificial intelligence. At the present time, there has already been accumulated a sufficient array of experimental data on consciousness that require philosophical comprehension and they, in turn, influence the direction of research into the philosophy of consciousness. At the same time, in the process of philosophical comprehension of natural scientific data on consciousness, a methodological complexity arises that requires reflection. Empirical data obtained in the field of the natural sciences are not a homogeneous array of data, and this is a problem in the methodology of studying consciousness.

A brief overview of publications on the topic. Many philosophers dealt with the study of the specifics of the methodology of studying consciousness. For example, David Chalmers named the problem of understanding subjective experience the "hard problem" (Chalmers 1995, 1996). Us- ing Thomas Nagel's famous example, even if we had a complete knowledge of bat brains, we would never understand what it is like for the bat to have a sonar sense (Nagel 1974). The author also singles out an article P. Feyerabend "Realism. Rationalism and Scientific Method" (Feyerabend, 1999).

Materials and methods. In the course of the research, I used the principles, methods and techniques of the analysis of phenomena developed in modern philosophy and natural sciences. In particular, the epistemological principles of holism and complementarity played an important role in the study of the problem of consciousness, which allowed us to regard consciousness as a specific object of investigation.

Purpose. The purpose of this article is to reveal the essence of the methodological problems of investigating consciousness in connection with the change in the methodological characteristics of research programs.

Results and its discussion. Modern philosophy of consciousness supports the existence of various approaches as an important factor in the development of science. P. Feyerabend said that the existence of a set of equal types of knowledge contributes to the growth of knowledge and the development of the individual, and the most fruitful periods in the development of science are the periods of the struggle of alternatives, the origins of which are contained in the difference of the world outlook and social positions of scientists. [4; 83] Not less value for the development of science is represented by alternative theories, since in the process of their interaction and critical analysis, not only differences of theories are revealed, but also their similarity.

The value of philosophical innovations in the field of philosophy of consciousness is commensurate with that critical assessment of the current state of science. P. Merkulov draws attention to the fact that "at the disposal of researchers was a huge array of information on the functioning of the human cognitive system, which is incomparable in its scope and reliability with the knowledge that has been accumulated by mankind during the past millennia." $[2 ; 36]$ Now there are fundamentally new experimental methods for studying the brain, thanks to the development of the digital environment. For example, neurobiology is working on a brain-computer interface (BCI), which greatly simplifies communication with devices for those who have certain physical characteristics. Also, significant changes have occurred in the philosophical methodology of the study of the human cognitive system. Such a combination of circumstances and causes explains the trend in the development of philosophical thought, in particular, an increased interest in the problem of consciousness. This is evidenced by many research strategies 
for solving the problem of consciousness and their interpretations.

In the conditions of methodological pluralism, the question of which philosophical approach is most effective and expedient is relevant. There are no single-valued criteria for optimality of the chosen strategy. Multiple, but one-sided approaches do not give the desired result. [3; 268-274]

In this situation, alternatives are possible:

1. Consideration of philosophical knowledge about consciousness from the standpoint of the principle of complementarity, then different interpretations is modes of describing consciousness complementing each other;

2. Development of an integrated approach that involves some kind of universal setting, which is a methodological invariant of constructing different approaches and concepts; Also, a language is needed that will correspond to the tasks of a comprehensive study;

3. Inclusion of interdisciplinary research in the interests of philosophy. But any of the alternatives assumes that there is some common (metaphysical, theoretical, methodological) basis for its implementation.

As soon as we raise questions about the effectiveness, adequacy of attitudes and approaches, methodological difficulties, we are faced with the problem of reflection. The main philosophical method of awareness of consciousness is multilevel reflection. [1; 3-18] However, the problem exists in the fact that reflection as a process of studying consciousness is both its property and the level of consciousness. At the same time, the choice of the method of reflection is influenced by its irreflexive (ordinary) consciousness, which is a priori of the researcher. There is a paradoxical situation: on the one hand, in everyday representations one sees one of the reasons for the multitude of philosophical interpretations of consciousness; on the other hand, they are presented as an implicit basis for solving the problem of consciousness.

The philosophical attitude is the orientation of philosophical reflection, which contains the relation to the object of thought and the preliminary, extremely schematized representation of it. The philosophical attitude is an axiomatic proposition, metaphysical parameters, and ontological postulates that explicitly or implicitly express the essential characteristics of consciousness and set the methodological foundations of interpretation in the comprehension of a particular problem of consciousness.

On the basis of one philosophical attitude, several different approaches can co-exist, read as interpretations of attitudes involved in the development of certain aspects of the problem of consciousness. The methodological basis for solving the problem of consciousness is the search for an adequate philosophical attitude to the approach. In this case, it is necessary to take into account the specific nature of the methodological attitude towards consciousness, on the basis of which a research program is being developed.

Cognitive approach. Under the conditions of the cognitive approach, operations are explored that allow us to identify significant connections within the consciousness, if consciousness is represented as a biological system; also to reveal the connections between the physical states of the human body and mental processes. It is possible that the cognitive method presupposes some preservation of the traditional views of philosophers in describing the nature, structure and evolution of consciousness, which consist in a close connection between the physical state of a person and his mental processes. But in the modern world, the philoso- pher cannot limit his studies on the activity of consciousness to the only conclusion about the existence of dualism - physical and mental, material and ideal, bodily and spiritual. This idea of the identity of the physical and the psychic over time is transformed into a physicalist concept of consciousness, for which a conceptual hypothesis based on the method of reduction, including modeling of the human psyche, is characteristic.

When we trying to connect two different worlds - physical and mental, often arise difficult, which generate skepticism about the existence of consciousness as an independent reality. In the framework of natural science research, R. Penrose compares consciousness with fundamentally noncomputable quantities in mathematics or quantum mechanics. R. Penrose is confident that "nothing in our physical theory of the structure of the universe allows us to explain why some objects have consciousness, while others do not." [5; 37-49] Regardless of R. Penrose's convictions, the quantum theory of consciousness is being developed. This theory suggests that consciousness is closely related to physical processes taking place at the quantum level, and perhaps this path will lead to some results of the study of consciousness in natural-science studies.

Coevolutionary approach. The concept of coevolution appeared in the twentieth century, but the notion of codevelopment of man and nature was still encountered in ancient authors. The historical picture of understanding coevolution comes to the fact that until the New Time the term was not required, because co-development was a natural process for philosophers of the ancient period. In the middle Ages the question of co-development was not raised, since there was an anthropomorphic God who was opposed to nature. In the modern era, the process went in the opposite direction, and the interest in individual elements of the whole gradually increased, classical science began to develop, which in the 19th century began to develop has undergone a collapse. And in the beginning of XX century science has acquired a new one that constructed holism in itself. Against this background, of course, there were problems of coevolution of human nature. The modern coevolutionary approach is aimed at developing the problem of the interaction of consciousness as a Biosystems and the environment. In such a spectrum, consciousness and the environment should be understood as complex systems with coordinated relations, based on changes in the parameters of interaction between the Biosystems and the external environment.

In the natural and humanities within the framework of coevolutionism, questions remain about ethical aspects of the process of scientific experiment, the specifics of bioethics. The blurring of boundaries between the humanities and the natural sciences is palpable when it comes to the empirical nature of research. How will the results of research affect the life of the person as a whole: will they harm, or will they benefit? One can only assume that for understanding objective truth, there is not enough knowledge and methods of another sphere. Science originated in a synthetic form and it again needs to move into this state.

Dynamic approach. This approach is based on the idea that consciousness and the unconscious are necessary and interrelated components of the human cognitive system. The individual cognitive system is represented here as a dynamic, hierarchically complex and highly organized whole, whose state is determined by the relations of the conscious and the unconscious. In the process of evolution, new forms of the 
relationship of these fundamental subsystems arise, there is a tendency to expand consciousness and strengthen its management functions in relation to the unconscious.

Most of the natural science studies of consciousness and the unconscious are interdependent with research in the field of neuroscience. Since it is in the structure and functions of the human brain that the main evolutionary acquisitions of a person are fixed. You can identify a set of traditional problems that are considered in connection with the study of subjective reality: 1) the problem of localization of mental functions of consciousness and the unconscious in the human brain; 2) the problem of the cause-effect relationship between the activity of consciousness and the activity of the brain. To these traditional problems, it is quite possible to include the problem of the multiplicity of the substrata of consciousness, it seems, it could arise precisely in connection with the studies of artificial intelligence. But the philosophical and even mythological prehistory of the problem already posed the question: Does the soul (the psyche) have only a person or nature in general, animals, plants, artifacts and other various "substrates" and "substances"?

Before posing the question: What results can scientific research of consciousness and the unconscious give for the development of philosophical ideas about the subject of cognition and the dynamics of consciousness and the unconscious in the structure of the subject of cognition? It must be pointed out that such a question should be preceded by the systematization of the basic conceptual and methodological approaches to the study of consciousness and subjective reality in the natural sciences within which empirical data were obtained.

Conclusion. With the increasing interest of modern man to the problem of consciousness, there is a competitive struggle among scientists, which multiplies approaches to solving the problem of consciousness. So next to the actual philosophical decisions in the philosophy of consciousness, specific scientific and interdisciplinary interpretations are involved. Through this synthesis, the analysis of scientific results in the sphere of cognition of consciousness stimulates the rapid reaction of philosophy to scientific innovation. For example, thanks to cognitive sciences, it is possible to exper- imentally test some philosophical ideas regarding the solution of the problem of consciousness. In addition, the results of experimental studies of cognitive structures and mechanisms within the framework of neuroscience create a basis for empirical substantiation of a number of theoretical positions in philosophy. To describe the mechanisms of the work of consciousness in philosophy, natural science methodologies and models are increasingly being used. These are models of artificial intelligence, synergetic models (the model of dynamic chaos, the model of the process of selforganization), the classical model of physics (for describing everyday consciousness), the quantum model (for solving the problems of the relationship between consciousness and the unconscious, modeling of mental processes). However, there remains a problem of methodological properties concerning the use of natural-science research methods and generalizations based on them in the philosophical explanation of the phenomenon of consciousness. At the present stage of the development of science, the process of dialogue between researchers of consciousness and cognition may have entered a phase of reviewing the dialogue interpretation and coherence of meaning contained in the concept of consciousness of different directions of the philosophy of consciousness, with the meaning of the context created together. This dialogue is so dynamic that it seems almost impossible to trace all aspects of its development. Perhaps, it is worth paying special attention to the methodological invariants of constructing the context of consciousness. Such an approach would allow us to put forward hypothetical theories about the future possible meanings of such an element of this dialogue as consciousness.

Prospects of the philosophical analysis of the results of the study of consciousness, its origin, formation and development are based on conceptual models, relying on concrete scientific material. It rather speaks not so much of the hypothetical possibility of constructing a single unified theory of consciousness (the "science of consciousness"), but rather the direct development of the philosophy of consciousness, which does not reject the value of natural scientific results, preserving the status of philosophical thinking and understanding its meaning for solving the problem of consciousness.

\section{ЛИТЕРАТУРА}

1. Кузнецов В.Ю. Сдвиг от классики к неклассике и наращивание порядков рефлексии в философии // Вестник Московского университета. 7(1), 2008. С. 3-18.

2. Меркулов И. П. Когнитивная модель сознания // Эволюция. Мышление. Сознание. М: Канон+, 2004. С. 36.

3. Шульга Е.Н. Философии сознания: концепции, подходы и теория интерпретации // Философия сознания: классика и современность. М: Издатель Савин С.А., 2007. С. 268-274.

4. Feyerabend P. Realism. Rationalism and Scientific Method. Cambridge: Philosophical Papers. Vol. 3, 1999. C. 83.

5. Penrose R., Gardner M. The Emperor's New Mind: Concerning Computers, Minds, and the Laws of Physics (Popular Science). USA: Oxford University Press, 2002. C. 37-49.

\section{REFERENCES}

1. Kuznecov V. Ju. The shift from the classical to the nonclassic and the building up of the order of reflection in philosophy. M: Bulletin of Moscow University. No. 7(1), 2008. p. 3-18.

2. Merkulov I. P. Cognitive model of consciousness // Evolution. Thinking. Consciousness. M: Kanon+, 2004. p. 36.

3. Shul'ga E.N. Philosophy of Consciousness: Concepts, Approaches and Theory of Interpretation // Philosophy of Consciousness:

Classics and Modernity. M: Publisher Savin S.A., 2007, p. 268274.

4. Feyerabend P. Realism. Rationalism and Scientific Method. Cambridge: Philosophical Papers. Vol. 3. 1999, p. 83.

5. Penrose R., Gardner M. The Emperor's New Mind: Concerning Computers, Minds, and the Laws of Physics (Popular Science). USA: Oxford University Press. 2002, p. 37-49.

\section{Методологическая сложность в изучении сознания}

\section{К. И. Зобенко}

Аннотация. Почему мы сознаем? Как может быть, что информация, обрабатываемая в мозге человека, сопровождается субъективным опытом? Неотъемлемой частью проблемы сознания является методология его решения. Автор рассматривает различные методы исследования сознания как сближение основных свойств сознания в связи с изменением методологических характеристик исследовательских программ. Методологический плюрализм, характерный для современной философии сознания, проявляется, прежде всего, как набор исследовательских стратегий для решения проблемы сознания и их интерпретаций.

Ключевье слова: сознание, методология, плюрализм, философская установка, рефлексия, подходьл. 


\title{
Формування екологічної культури майбутніх учителів природничих спеціальностей
}

\author{
В. В. Гончарук \\ Національний дендрологічний парк «Софіївка» НАН України, м. Умань, Україна \\ Corresponding author. E-mail: goncharuk424@ukr.net
}

Paper received 20.05.18; Accepted for publication 27.05.18.

\section{https://doi.org/10.31174/SEND-PP2018-170VI70-16}

\begin{abstract}
Анотація. Формування екологічної культури майбутніх учителів є складовою їх професійної підготовки. Виникає потреба внесення ефективних змін у зміст і методи підготовки фахівців відповідно до їх майбутньої діяльності. У статті розкрито проблему формування екологічної культури майбутніх учителів природничих дисциплін у закладі вищої освіти. Процес удосконалення екологічної культури студентів педагогічного напрямку підготовки має здійснюватися системно, реалізуючи конструктив трьох провідних факторів: екологічної освіти, екологічного виховання, еколого-практичної діяльності. Досліджено основні умови забезпечення екологічної культури студентів, що створюють об'єктивні можливості розробки певної педагогічної системи. Від якості підготовки майбутніх учителів буде залежати рівень культури й моральності майбутніх поколінь.
\end{abstract}

Ключові слова: екологічна освіта, екологічна культура, екологічне виховання, організація навчально-виховної роботи, педагогічні умови, педагогічна система.

Вступ. У контексті реформування вітчизняної системи освіти, іiі інтеграції у європейський освітній простір зростають вимоги до підготовки педагогів, які навчатимуть і виховуватимуть нові покоління громадян нашої держави, конкурентоспроможних на світовій арені. Учитель майбутнього має не просто бути ретранслятором знань із предмета, а повинен сприяти самореалізації кожного учня в навчальній діяльності, вміти підготувати школярів до життя в сучасних соціально-економічних умовах. Професійну підготовку майбутніх педагогів необхідно спрямувати на їхній особистісний та професійний саморозвиток, формування нестандартного мислення, творчого підходу до роботи, вироблення власного методичного стилю. Вища педагогічна школа покликана стати школою професійного та духовного формування особистості майбутнього вчителя, забезпечити успішне проходження кожним студентом власної траєкторії професійного становлення.

На сучасному етапі розвитку українського суспільства активне впровадження ідей екологічної культури регламентовано Національною доктриною розвитку освіти України у XXI ст., Концепцією екологічної освіти в Україні, Національною стратегією розвитку освіти в Україні на 2012-2021 рр., Педагогічною Конституцією Європи тощо. Питання реалізації зазначених документів пов'язано 3 внесенням коректив у професійну підготовку майбутніх фахівців, у тому числі й майбутніх учителів природничих дисциплін.

Виявлення та оцінювання ціннісних пріоритетів сучасного вчителя природничих дисциплін, розвитку його аксіосфери, дослідження специфіки екологоціннісних орієнтацій у процесі його професійної підготовки показало, що ці аспекти набувають сьогодні стратегічного характеру, а їх вирішення є найважливішим і найактуальнішим завданням вищої педагогічної школи.

Короткий огляд публікацій по темі. У теорії і практиці вищої педагогічної освіти накопичено значний досвід, що є основою формування системи цінностей у майбутніх фахівців природничих спеціальностей загалом та ціннісного ставлення до навколишнього середовища у молоді зокрема. Насамперед, це наукові праці, у яких розкрито теоретико-методичні основи екологічної освіти й виховання у вищій школі (Н. Бібік, О. Біда, Л. Білик, Ю. Бойчук, Н. Демешкант, Н. Лисенко, Л. Лук'янова, В. Онопрієнко, О. Плахотнік, Н. Рідей, Т. Саєнко, С. Совгіра, Г. Сорокіна, Г. Тарасенко та ін.), посилення ролі екологічної домінанти в навчально-виховному процесі загальноосвітніх шкіл (К. Гуз, В. Ільченко, Г. Пустовіт, С. Шмалєй та ін.). Ідеї неперервної екологічної освіти розвиваються у роботах вітчизняних і зарубіжних педагогів і психологів, таких як В. Вербицький, Е. Гірусов, М. Дробноход, І. Зязюн, В. Крисаченко, Б. Лихачов, М. Моісеєв, Н. Ничкало, Г. Пустовіт, Н. Реймерс, В. Рибалко та ін. Ряд наукових робіт, присвячених аналізу проблеми формування екологічної культури, здійснювали такі науковці: І. Грабовська, І. Сафонов, М. Реймерс, Б. Ліхачов, М. Храменко, О. Ожегова, О. Ніконорова, Г. Швебс.

Формування екологічної культури студентів вищих навчальних закладів вивчали Г. Білявський, М. Бойчева, В. Бровдій, М. Грейда, Н. Лисенко, О. Мітрясова, О. Микитюк, Т. Нінова, К. Ситнік, Є. Флешар, О. Чернікова, М. Шаповал, Е. Шапокене, М. Швед. Саме тому, М. Моїсеїв вважає, що формування екологічної культури особистості повинне стати незамінною частиною діяльності всієї системи навчання [4].

Мета. Мета статті полягає в обгрунтуванні теоретико-методичних засад формування екологічної культури майбутніх учителів природничих спеціальностей у процесі професійної підготовки.

Матеріали та методи. На різних етапах дослідження для розв'язання поставлених завдань використовувалися такі методи дослідження: теоретичні аналіз психолого-педагогічної літератури, контентаналіз основних понять, узагальнення, моделювання 3 метою розробки моделі та технології формування екологічної культури вчителів; емпіричні - анкетування, спостереження, письмове та усне опитування, тестування 3 метою визначення критеріїв і рівнів сформованості екологічної культури, педагогічний експеримент (констатувальний та формувальний етапи) для перевірки ефективності авторської технології форму- 
вання екологічної культури; прогностичні - метод незалежних експертних оцінок із метою впровадження та апробації розроблених навчально-методичних матеріалів; статистичні - методи математичної обробки кількісних даних дослідження.

Результати та їх обговорення. Виховання особистості з високим рівнем екологічної культури і свідомості повинне стати одним із головних важелів у вирішенні надзвичайно гострих екологічних проблем сучасної України. Найголовнішою метою екологічної освіти у наш час $є$ формування екологічної культури дітей і молоді, що передбачає виконання таких завдань: відродження кращих традицій українського народу, в основі яких тісний взаємозв'язок людини із довкіллям; відродження духовно-почуттєвого розуміння світу природи; формування вміння приймати відповідальні рішення, спрямовані на збереження природи.

Постановка проблеми. Проблема формування екологічної культури - одна 3 найбільш актуальних проблем на сучасному етапі розвитку нашого суспільства, від вирішення якої залежить оздоровлення нації в цілому. Процес формування екологічної культури студентів є складним, суперечливим і багатоетапним. На основі аналізу психолого-педагогічних досліджень проблеми, власного теоретичного пошуку виявлено такі структурні елементи екологічної культури: екологічні знання - екологічне мислення - екологічна свідомість - екологічний світогляд - екологічна етика - екологічна культура.

Реформування змісту вищої освіти в Україні орієнтоване на гуманізацію, екологізацію, що ставить перед системою освіти принципово нові завдання. Екологічна освіта $\epsilon$ одним із основних засобів реалізації ідей сталого розвитку держави, зміст якої має грунтуватися на українському державотворенні. Суттєвого значення у цьому контексті набуває екологічна освіта, кінцевою метою якої є становлення екологічної культури особистості.

С. Совгіра слушно зазначила, що формування екологічної культури майбутнього викладача, в тому числі й природничих дисциплін, повинне проходити через: набуття екологічних знань, формування екологічного мислення, світогляду, етичних принципів поведінки у природі, забезпечення підтримки фізичного стану для проведення краєзнавчих екскурсій, експедицій, подорожей, вироблення активної природоохоронної позиції, формування необхідних якостей вихователя. Отже, екологічну культуру вчителя можна визначити: як засвоєння особистістю і постійне збільшення певних екологічних знань і навичок, коли вони органічно поєднуються зі знаннями екологічної ситуації і становлять своєрідний екологічний світогляд; вироблення екологічної свідомості, яка передбачає використання набутих знань у житті та практичній діяльності; здатність особистості творчо мислити та постійно самовдосконалюватися [6, с. 67].

Сьогодні вчені (Ю. Давидов, М. Кисельов, В. Межуєв, Я. Мінкявечюс та ін.) стверджують, що культура не стільки відрізняється від природи, скільки пов'язана $з$ нею культура $є$ людським ставленням до природи [8, с. 33]. Екологічна культура виступає регулятором людської діяльності. Вона є за своєю суттю своєрідним «кодексом поведінки», що лежить в основі екологічної діяльності та екологічної поведінки. За змістом її слід розглядати як сукупність знань, норм, стереотипів і правил поведінки людини в оточуючому iї природному світі [1, с.115]. У процесі навчання студенти повинні навчитися не лише обгрунтовувати свої світоглядні позиції, а й користуватися здобутими знаннями у повсякденному житті. Отже, чітко простежується світоглядний та прагматичний аспекти. Це й становить основний зміст екологічної освіти на сучасному етапі.

М. Мойсєєв визначає три істотно різних напрямки екологічної освіти. Перший напрямок - світоглядний, завдяки якому продовжується освітній (виховний) напрямок, який було закладено ще в середній школі. Незалежно від тієї галузі діяльності, до якої буде залучений майбутній фахівець, він повинен мати необхідний світогляд, певним чином сформоване філософське підгрунтя для своєї діяльності та емпірично обгрунтоване раціоналістичне бачення в біосфері. У межах другого напрямку розглядається екологічний професіоналізм майбутнього фахівця. Цей напрям $є$ орієнтованим на майбутню професійну діяльність студента, зокрема знання ним основних екологічних принципів і новітніх технологій, здатність до раціонального й екологічно доцільного вирішення професійних завдань із урахуванням усіх природоохоронних вимог тощо. Ця підготовка визначається специфікою навчальних закладів у процесі професійної підготовки фахівців різних галузей. Згідно із третім напрямком існує необхідність у підготовці фахівців, які здатні вирішувати множинні завдання, що виникають у процесі взаємодії у системі «людина-природа», фахівців, які володіють системними екологічними знаннями, а також всебічною підготовкою в галузі норм права, економіки та готові до вирішення повсякденних екологічних завдань та глобальних екологічних проблем [3]. За нашим баченням, екологічна освіта - це неперервний процес набуття екологічних знань, вмінь і навичок природовідповідної діяльності.

Б. Ліхачов розглядає екологічну культуру як особливе утворення, яке грунтується на екологічних знаннях, включає глибоку зацікавленість у природоохоронній діяльності, грамотне іiі здійснення, багатство етично-естетичних відчуттів і переживань, що породжуються спілкуванням із природою [2]. Відзначаючи складну структуру екологічної культури, автор виділяє такі основні їі аспекти: екологічну культуру результату діяльності людини із перетворення природного середовища в напрямку, що відповідає фізіологічним та соціальним потребам людини; екологічна культуру, яка характеризує рівень розвитку екологічної свідомості у соціальних суб'єктів, починаючи від окремої особистості й закінчуючи людством у цілому, у якому відображено ставлення до природного середовища як життєвонеобхідної екологічної цінності; екологічну культуру - творчу діяльність людей щодо екологічного засвоєння природного середовища, під час якого створюються, зберігаються, розподіляються і споживаються екологічні цінності [2].

I. Суравегіна визначає екологічну культуру як динамічну єдність екологічних знань, позитивного ставлення до них (екологічних настанов, цінностей) та реальної діяльності людини у навколишньому середовищі [7]. На думку дослідниці, необхідним елементом 
екологічної культури є відповідальність у ставленні до природного середовища.

Проводячи аналіз цієї складної дефініції, Г. Пустовіт визначає екологічну культуру як історично обумовлене явище, що постійно зазнає змін і корекції у світоглядному контексті, $\epsilon$ обов'язковою умовою людського буття і виступає як: засіб самоорганізації (матеріальних і духовних) сутніх сил особистості у конкретній екологічній ситуації, який дозволяє на принципах гармонії і доцільності поєднати два світи природний і соціальний; ціннісно-процесуальна категорія ставлення людини до власних потреб і можливих способів їх задоволення; життєвонеобхідних потреб природних об'єктів, як рівноправних партнерів у системі «природа-людина-суспільство»; процесуально-предметне втілення природоперетворюючої діяльності особистості у довкіллі з урахуванням соціальноекологічних обмежень і корекції росту необгрунтованих потреб людини; умова формування людини нового типу, основою поведінки якої в навколишньому середовищі є норми моралі, глибоке розуміння незаперечної цінності всіх без винятку природних об'єктів, неповторності природи та корекція власних життєвих потреб на ії̈ користь. На думку автора, екологічна культура особистості кардинальним чином змінює поведінку людини у довкіллі, чим забезпечується стабільне формування екологічної вихованості особистості, й відповідно іiі діяльність не порушує рівновагу у навколишньому середовищі, що в кінцевому результаті призводить до зростання якості життя як нинішніх, так і майбутніх поколінь [5, с. 64-65].

На думку С. Флешар, екологічна культура - це особливе особистісне утворення, що складається із таких елементів: здатність бачити специфіку та складність природних явищ, знаходити в них взаємообумовлені зв'язки й правила поводження 3 ними; цілісність знань про навколишнє середовище; здатність логічно мислити у межах екологічної безпеки; готовність до застосування законів, що охороняють навколишнє середовище; здатність до створення конструктивних етичних положень, які регулюють відносини людини 3 навколишнім природним середовищем; здатність нести відповідальність за збереження навколишнього середовища [9].

Формування екологічної культури полягає у наданні студентам екологічних знань, формуванні екологічного стилю мислення, вивчення правил доцільної поведінки та здорового способу життя. Виходячи 3 цього, можна виокремити такі критерії оцінювання екологічної культури студента: екологічні знання; екологічні мотиви і цінності; поведінку в природі; посильну участь в екологічній діяльності. Одним із шляхів формування екологічної культури студентів $є$ екологізація змісту навчальних предметів. Разом із тим виховання екологічно культурної особистості передбачає докорінну перебудову мислення і поведінки. Формування екологічної культури не мислиме без усвідомлення єдності людини і природи. Природне довкілля - це не просто природне середовище існування, це - форма, в якій відбувається зростання людини як повноцінної особистості. Тому найважливішим ланцюгом у процесі формування екологічної культури є польові практики із природничих дисциплін, у зміст яких включені завдання комплексного вивчення рослинного і тваринного світу. Важливим показником екологічної культури студента $\epsilon$ його суспільно значущі дії та вчинки. Тому особливої ваги у формуванні екологічної культури набуває виховна діяльність педагогічних закладів вищої освіти, яка зосереджується на конкретних етичних нормах, що має особистісний сенс для студента.

На наш погляд, поняття «екологічна культура» має широкий зміст, бо в нього, разом із природними, включені й соціальні чинники, що відображають матеріальне та духовне виробництво, соціальну діяльність людей i визначають організацію суспільства. Специфіка екологічної культури визначається, насамперед, своєрідністю діяльності, широким спектром функцій, що виконуються, з яких основними є: творче усвідомлення нових наукових ідей; визначення свого ставлення до них та до дійсності, що змінилася; педагогічні, виховні функції.

Висновки. Ми зробили висновок про необхідність включення у зміст екологічної культури таких компонентів: еколого-ціннісних орієнтацій, екологозначущих знань, еколого-орієнтованих відносин, еколого-виправданої практичної діяльності. Структура екологічної культури відображає аксіологічноінформаційно-емоційно-діяльнісну сутність загальної культури; співвідноситься 3 цілісним освітньовиховним процесом, у якому вона може бути сформована. Екологічна культура майбутнього вчителя природничих спеціальностей - це інтегральне утворення, що формується у процесі професійної освіти у закладі вищої освіти й грунтується на екологічних знаннях і вміннях, екологічній свідомості, екологічному стилі мислення та діяльності, які проектуються на його професійну діяльність. Стиль розкривається у поєднанні таких фізичних, психологічних та соціокультурних якостей, які дозволяють на всіх рівнях життєдіяльності зберігати органічний зв'язок із природою. Екологічна культура особистості вчителя виявляється у свідомості, мисленні, поведінці. На основі узагальнення теоретичних підходів визначено особливості формування екологічної культури майбутніх учителів природничих спеціальностей: на рівні особистості формування навичок повсякденної екологічно виправданої поведінки у побуті та професійній діяльності; уміння передбачати соціальні й екологічні наслідки економічних рішень; переконання необхідності використання у професійній діяльності новітніх екобезпечних технологій; на рівні групи - урахування у змісті робочих програм професійно орієнтованих дисциплін складових сталого розвитку; використання інноваційних педагогічних технологій освітнього процесу для інтеграції економічної, соціальної та екологічної складових сталого розвитку; проведення практик (навчальної, виробничої) на підприємствах, що застосовують безвідходні технології виробництва; залучення до навчального процесу фахівців екологічної сфери, що працюють на підприємствах із найвищим рівнем екологічної безпеки; на рівні соціуму врахування морально-екологічного імперативу у процесі реалізації економічних інтересів підприємства, регіону, держави; розвиток людини у природі як мета й критерій соціально-економічного прогресу; формування системи уявлень про цінність природних ресур- 
сів, стратегію сталого розвитку, проблеми збереження здоров'я та навколишнього середовища.

Результати аналізу, консультацій із викладачами, вивчення досвіду інших навчальних закладів, дали змогу зробити висновок, що у межах будь-якої однієі дисципліни формування екологічної культури не може відбуватися сповна; екологічна освіта має міжпре- дметний характер, тому під час вивчення дисциплін циклу загальноприродничої та професійної підготовки є досить значні можливості для формування екологічної свідомості та культури, а також загальнолюдських цінностей, якими повинні керуватися студенти природничого факультету.

\section{ЛІТЕРАТУРА}

1. Крисаченко В. С. Екологічна культура: теорія та практика: навч. посібник / В. С. Крисаченко. - К. : Заповіт, 1996 $-352 \mathrm{c}$.

2. Лихачев Б. Т. Экология личности / Б. Т. Лихачев // Педагогика. - 1993. - № 2. - С. 19-24.

3. Моисеев Н.Н. Современный антропогенез и цивилизованные разломы. Эколого-политический анализ. - М. МНЭПУ, 1994. - 47 c.

4. Моисеев Н. Н. Историческое развитие и экологическое образование / Н. Н. Моисеев. - М. : МНЭПУ, 1995. - 52 с.

5. Пустовіт Г. П. Теоретико-методичні основи екологічної освіти і виховання учнів 1-9 класів у позашкільних навчальних закладах: монографія / Г. П. Пустовіт. - К. - Луганськ : Альма-Матер, 2004. - 540 с.

6. Совгіра С.В. Підготовка майбутнього вчителя до екологічного виховання старшокласників (на краєзнавчому матеріалі): дис. канд. наук : 13.00.04 / Совгіра Світлана Василівна. - Умань, 2000. - 160 с.

7. Суравегина И. Т. Методические системы экологического образования / Суравегина И. Т. // Советская педагогика. 1988. - № 9. - C. 31-35.

8. Тарасенко Г. С. Взаємозв'язок естетичної та екологічної підготовки вчителя в системі професійної освіти: монографія / Г. С. Тарасенко. - Черкаси, 2006. - 308 с.

9. Флешар Є. Дидактичні основи підготовки студентів майбутніх вчителів-біологів до реалізації екологічної освіти: автореф. дис. ... д-ра пед. наук: 13.00 .02 / Є. Флешар. - К., 2000. - 30 c.

\section{REFERENCES}

1. Krischenko V. S. Ecological Culture: Theory and Practice: Teach. manual / VS Krisachenko. - K.: Testament, 1996. 352 pp.

2. Likhachev B. T. Ecology of personality / B. T. Likhachev // Pedagogics. 1993. № 2. P. 19-24.

3. Moiseev N. N. Modern anthropogenesis and civilized faults. Ecological-political analysis. - M.: MNEPU, 1994. 47 p.

4. Moiseyev N. N. Historical development and ecological education / N. N. Moiseev. - Moscow: MNPEU, 1995. 52 p.

5. Pustovit G. P. Theoretical and methodological foundations of ecological education and education of pupils of grades 1-9 in extracurricular educational institutions: monograph / G.P. Pustovit. - K. - Lugansk : Alma-Mather, 2004. 540 p.

6. Sovhira S.V. Preparation of the future teacher for environmental education of senior pupils (on the local lore material): diss. Cand. Sciences: 13.00.04 / Sovhira Svetlana. - Uman, 2000. $160 \mathrm{p}$.

7. Suravegina I. T. Methodical systems of ecological education / Suravegina I. T. // Soviet pedagogy. - 1988. № 9. P. 31-35.

8. Tarasenko G. S. Interconnection of aesthetic and ecological teacher training in the system of vocational education: monograph / G.S. Tarasenko. - Cherkasy, 2006. 308 p.

9. Fleshar Ye., Didactic Fundamentals of Preparing StudentsFuture Teachers-Biologists for the Implementation of Ecological Education: Author's abstract. dis ... Dr. Ped. Sciences: 13.00.02 / Ye. Fleshar. - K., 2000. 30 p.

\section{Formation of ecological culture of future teachers of natural specialties}

\section{V. Goncharuk}

Abstract. Formation of ecological culture of future teachers is the part of their training. There is an objective need for making effective changes to the content and methods of training specialists according to their future performance. The article discusses the need to improve the formation and development of ecological culture of future teachers of natural sciences in the institution of higher education. The formation of ecological culture of students of pedagogical direction of training should be carried out systematically, realizing constructive three major factors: environmental education, environmental upbringing, ecological practice. We study the basic conditions for the formation of ecological culture of students, creating objective possibilities of the development of educational system of signification the process. The quality of training of future teachers will depend on the level of culture and morality of future generations.

Keywords: ecological education, ecological culture, ecological upbringing, organization of educational work, pedagogical terms, pedagogical system.

\section{Формирование экологической культуры будущих учителей естественных специальностей}

\section{В. В. Гончарук}

Аннотация. Формирование экологической культуры будущих учителей является частью их профессиональной подготовки. Возникает необходимость внесения эффективных изменений в содержание и методы подготовки специалистов в соответствии с их будущей деятельностью. В статье раскрыта проблема формирования экологической культуры будущих учителей естественных дисциплин в учреждении высшего образования. Процесс усовершенствования экологической культуры в студентов педагогического направления подготовки должно осуществляться системно, реализуя конструктив трех ведущих факторов: экологического образования, экологического воспитания, эколого-практической деятельности. Исследованы основные условия обеспечения экологической культуры студентов, какие создают объективные возможности разработки определенной педагогической системы. От качества подготовки будущих учителей будет зависеть уровень культуры и нравственности будущих поколений.

Ключевые слова: экологическое образование, экологическая культура, экологическое воспитание, организачия учебновоспитательной работы, педагогические условия, педагогическая система. 


\title{
Дослідження психологічних детермінант альтруїзму волонтерів-медиків
}

\author{
К. О. Талалаєв ${ }^{1}$, Н. В. Кривцова ${ }^{1}$, І. В. Бринза ${ }^{2}$, \\ ${ }^{1}$ Одеський національний медичний університет, Одеса, Україна \\ Corresponding author. E-mail: kryvtsova.natalya@gmail.com \\ ${ }^{2}$ Державний заклад «Південноукраїнський національний педагогічний університет імені К.Д. Ушинського», Одеса, Україна \\ Corresponding author. E-mail: brynza3691@gmail,com
}

Paper received 15.05.18; Accepted for publication 24.05.18.

\section{https://doi.org/10.31174/SEND-PP2018-170VI70-17}

\begin{abstract}
Анотація. У статті представлено результати теоретико-емпіричного дослідження психологічних детермінант альтруїзму волонтерів-медиків. В дослідженні запропоноване метод моделювання. Аналіз отриманих моделей дозволив виявити провідні психологічні детермінанти природного альтруїзму, серед яких: почуття власної гідності та дослідницький інстинкт, не провідними психологічними детермінантами виявилися: інтенсивне-перетворювальний тип поведінки в інноваційної ситуації, осмислене-інтенсивний тип реалізації різних інноваційних можливостей та лабільний тип поведінки особистості.

Ключові слова: волонтерська діяльність, альтруїстичний інстинкт, почуття гідності, дослідницький інстинкт, самореалізація інноваційно-дослідного потенціалу особистості.
\end{abstract}

Вступ. В основі докорінних соціальних змін на всіх рівнях знаходяться людино центрична модель і нооетика, бо йде переоцінка ролі особистості, розширення простору свободи, вибору себе та власного життя. Усталення особистісно-орієнтованої парадигми освіти, усвідомлення специфічної ролі професійного навчання у житті людини обумовлюють велике значення його гуманізації і гуманітаризації. При цьому питання забезпечення високої якості сучасної освіти безпосередньо пов'язане 3 такими категоріями, як розвиток, самореалізація, самоповага і альтруїзм, що посилює роль психологічної складової освітнього процесу. Актуальним стає визначення не стільки основних механізмів і психологічних умов перебігу навчальновиховного процесу та розробка практичних рекомендацій стосовно його оптимізації і інтенсифікації, скільки визначення головних тенденцій трансформації всього освітнього простору щодо самовдосконалення і творчої адаптивної самореалізації освіченої людини. Проте принциповим моментом є те, що гуманітарна освіта не вичерпується викладанням гуманітарних дисциплін, а й реалізується в напрямку забезпечення альтруїстичної спрямованості людини в цілому.

Як визначає законодавство України, «за своєю природою, метою, формами реалізації та принципами, волонтерство безпосередньо пов'язане із самореалізацією особистості, адже це форма активної, добровільної участі громадянина у житті спільноти, що сприяє як його особистісному росту, так і суспільному благу [3]. В умовах реформування системи вищої освіти України волонтерська діяльність стає ознакою народження нової культури нового суспільства, зокрема змістом світогляду українців. Саме тому в Одеському національному університеті розроблено «Положення про організацію волонтерського руху» (ухвалено на засіданні Вченої ради ОНМедУ від 01.09.2016 р. у протоколі №1), згідно з яким майже чверть студентівмедиків ОНМедУ вже багато років є волонтерами, а саме: беруть участь у благодійних акціях, стають донорами тощо. Серед напрямків реалізації волонтерського руху в університету обрано: догляд за хвори- ми, допомога інвалідам, самотнім, реабілітація постраждалим в надзвичайних ситуаціях, сиротам, а також усім, хто потребує підтримки у важкий для країни час, участь у збереженні навколишнього середовища та культурної спадщини тощо.

Таким чином, можна зазначити, що волонтерська діяльність реалізується у спільній соціокультурній діяльності особистості, сприяє реалізації нею основних людських потреб, більш збалансованому економічному та соціальному розвитку, створенню нових робочих місць тощо. При цьому дослідження сучасних психологів довели, що беручи участь у волонтерській праці, студентська молодь набуває нових знань, досвіду, практичних навичок і цінностей, що сприяють їх становленню як активних і відповідальних громадян [1 та ін.]. Аналіз процесу розвитку волонтерства, здійснений Е.М. Балашовим, доводить, що включення особистості у широке поле волонтерської діяльності приводить до позитивних змін її світоглядних позицій, комунікативної свідомості особистості, що спричиняє таким особистісним новоутворенням, як соціальна та інтелектуальна активність, соціальна компетентність, уміння діяти у нестандартних життевих ситуаціях [див 1, с. 62]. Проте теоретикоемпіричне дослідження питання психологопедагогічних аспектів волонтерства в Україні, а також законодавчо-правових основ його функціонування у нашій державі, дозволяють зробити висновку про те, що ще не створено чіткої та зрозумілої теоретичної і практичної бази діяльності волонтерів, а також відсутні грунтовні фундаментальні наукові дослідження досвіду провідних держав світу у цій галузі, зокрема не визначено пріоритетних напрямів розвитку волонтерського руху в умовах сучасних українських економічних та соціокультурних реалій, що могло б забезпечити розвиток такої важливої складової ланки самореалізації особистості в умовах сучасного соціокультурного середовища, як волонтерство, а також допомогти волонтерам зайняти важливу нішу у соціальному, економічному та духовному розвитку держави. 
Наш інтерес продиктовано пошуком психологічних детермінант, що впливають на формування та розвиток природного, інстинктивного альтруїзму особистості.

Метою даної статті $є$ виявлення та вивчення психологічних детермінант природного альтруїзму волонтерів-медиків.

Організація та методики дослідження. У діагностичний комплекс війшли класичні, широко відомі та психометрично ефективні психологічні методики. Опитувальник В.I. Гарбузова [5]. щодо визначення домінуючого інстинкту дозволив визначити рівень соціалізації і можливості фізичного виживання, рівень первинної спеціалізації і самоствердження, виділити сім типів індивідуальності (егофільний, генофільний, альтруїстичний, дослідницький, домінантний, лібертофільний, дігнітофільний). Використання даної методики дозволило також визначити «природність» прагнення особистості до альтруїзму. Індивідуально-типологічного опитувальника (ITO), автор Л.М. Собчик [7] надав можливості виявити провідні тенденції особистості, серед яких: індивідуально-окреслений тип сприйняття, переробки і відтворення інформації, суб'єктивної чутливості до явищ навколишнього життя; ознаки інтроверсивно- екстраверсивного типу, тривожно-агресивного типу, ригідне-лабільного і сенситивне-спонтанного типу. Для вивчення можливостей самореалізації інноваційного потенціалу особистості використовувано методика Ю.А. Власенко [2], для оцінки показників потреб у самоактуализації - тест САТ, автори Ю.Е. Алёшина, Л.Я. Гозман, М.В. Загика i М.Н. Крос в модифікації В.А. Соніна [6] і для вимірювання спрямованості особистості на дослідницьку діяльність використовуван опитувальник професійних переваг (ОПП), автор Дж. Холланд [4]. Зібрані первинні результати математично оброблені за допомогою комп'ютерного варіанта статистичної програми SPSS 21 v.64. В дослідженні прийняли участь студенти i аспіранти ОНМедУ, які приймають участь у волонтерському руху університету (269 осіб).

Результати дослідження та їх інтерпретація. Досліджуючи психологічні детермінанти, що впливають на природний альтруїзм волонтерів-медиків, нами було застосоване метод моделювання. Статистично значущу двох рівневу модель дерев класифікації за алгоритмом CHAID (100:50) представлено на рисунку 1.

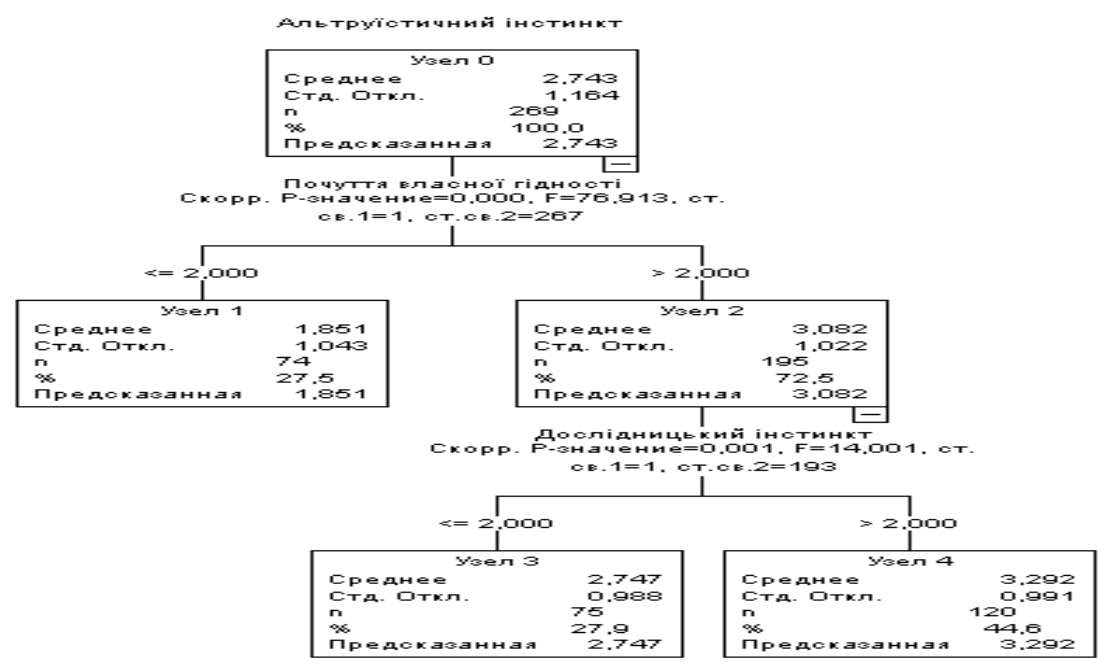

Рис.1. Модель класифікації психологічних детермінант природного альтруїзму волонтерів-медиків за алгоритмом CHAID (100:50)

Аналіз даної моделі показує, що серед всіх показників досліджуваних властивостей особистості в групі студентів і аспірантів ОНМедУ, які приймали участь в волонтерському руху, провідною детермінантною першого рівня, що визначає домінування природного альтруїзму (альтруїстичного інстинкту) є рівень «почуття власної гідності», другого рівня - «адаптація особистості за допомогою дослідницького інстинкту» 3 критичними значеннями 2,000 бали. Проте в даної моделі, як ми бачимо, якості особистості, які забезпечують їі самоактуалізацію та типи професійних переваг не мають статистично значущих величин, а значить не впливають на досліджуваний феномен.

3 метою уточнення ймовірнісної детермінації природного альтруїзму в групі волонтерів-медиків було знижено рівень строгості відбору показників властивостей особистості, що утворюють вплив на домінування альтруїстичного інстинкту було використано алгоритм CHAID (50:25). Отримано трьох рівневу модель древ класифікації, результати представлено на рисунку 2 і двох рівневу модель древ класифікації, результати представлено на рисунку 3.

Згідно трьох рівневої моделі серед досліджуваних властивостей особистості в групі волонтерів-медиків встановлено, що провідними детермінантами першого рівня природного альтруїзму також є показники «почуття власної гідності», на другому рівні - «дослідницький інстинкт». При цьому критичними величинами для цих характеристик виступає значення у 2,000 бали. Детермінацію третього рівня складає показник «інтенсивне-перетворювального типу поведінки в інноваційної ситуації» 3 критичним значенням у 18,000 балів. Показники самоактуалізації та типів професіональних переваг, як і в першої моделі не мають статистично значущих величин і також не 
впливають на рівень природного альтруїзму. У двох рівневої моделі на рисунку 3.

На наступному етапі моделювання психологічних детермінант природного альтруїзму в групі волонтерів -медиків за алгоритмом CHAID (50:25) вилучили iз аналізу детермінанти першого та другого рівнів (показники «почуття власної гідності» та «дослідницький інстинкт»), що були отримані на попередніх етапах аналізу (див. рис.2.). В результаті побудовано двох рівневу модель класифікації психологічних де- термінант природного альтруїзму, що представлена на рисунку 3. Згідно цієї моделі провідною детермінантою першого рівня, що визначає рівень домінування альтруїстичного інстинкту є показник «осмисленеінтенсивного типу реалізації різних інноваційних можливостей» із критичним значенням у 22,00 балів Детермінантою другого рівня природного альтруїзму виступає показник лабільного типу особистості із критичним значенням у 6,00 балів.

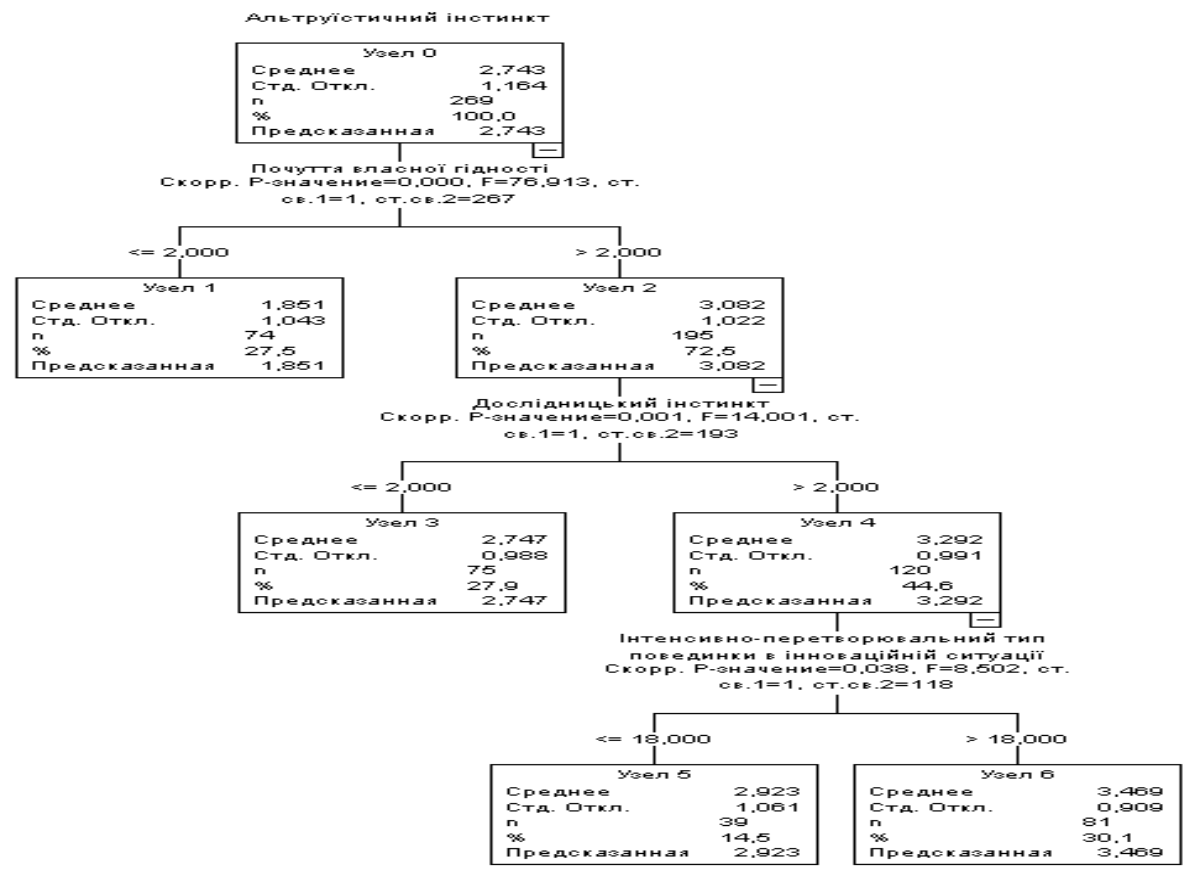

Рис. 2. Модель класифікації психологічних детермінант природного альтруїзму волонтерів-медиків за алгоритмом CHAID $(50: 25)$

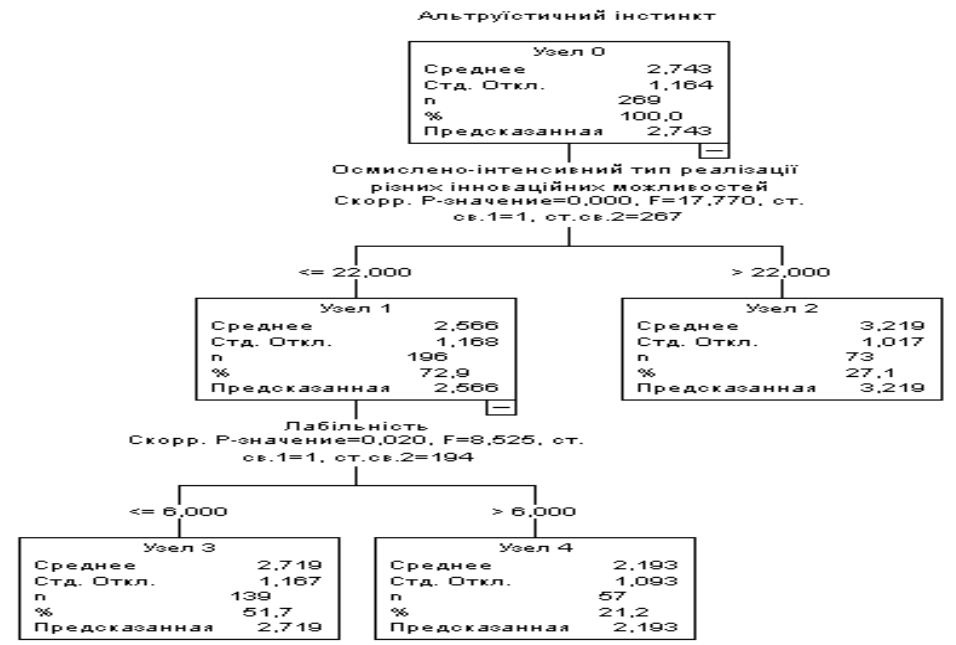

Рис. 3. Модель класифікації психологічних детермінант природного альтруїзму волонтерів-медиків за алгоритмом CHAID (50:25) за виключенням двох детермінант

Отримані результати можна інтерпретувати наступним чином. Розвинене почуття власної гідності та можливості самореалізації інноваційнодослідницького потенціалу особистості волонтерівмедиків детермінують альтруїзм, а в якості ймовірнісної детермінанти цієї природній форми адаптації до складних умов освітньої діяльності в осіб з низьким рівнем можливостей осмислене-інтенсивної самореалізації інноваційного потенціалу особистості може виступати лабільність нервової системи, що в певних умовах стає джерелом особистісної тенденції, яка сприяє дружелюбності та встановленню альтруїстичних міжособистісних стосунків. Отримані результати за методом модулювання знаходять своє підтвердження також і в інших дослідженнях $[1,7]$. Авторами цих робіт констатується, що респондентів з яскраво вираженим прагненням до волонтерства характеризує альтруїзм, високий рівень почуття власної гід- 
ності, їх зацікавленість, емоційне залучення в цю діяльність тощо.

Таким чином, результати теоретико-емпіричного дослідження психологічних детермінант природного альтруїзму волонтерів-медиків дозволяють зробити такі висновки:

1. В сучасних умовах реформування системи вищої освіти України актуальним стає питання створення умов для студентів, магістрантів і аспірантів медиків щодо залучення їх до волонтерської діяльності.

2. За результатами моделювання за алгоритмом CHAID (100:50) встановлено, що провідними психологічними детермінантами природного альтруїзму $є$ почуття власної гідності та дослідницький інстинкт. За алгоритмом CHAID (50:25) до зазначених провід- них психологічних детермінант додається інтенсивнеперетворювальний тип поведінки в інноваційної ситуації. За алгоритмом CHAID (50:25) з виключенням детермінант «почуття власної гідності» та «дослідницький інстинкт» першою детермінантою стає осмислене-інтенсивний тип реалізації різних інноваційних можливостей, а другою лабільний тип поведінки особистості. Показники самоактуалізації та типів професіональних переваг у всіх моделях не мають статистично значущих величин і не впливають на рівень розвитку природного альтруїзму.

3. Розвиток природного альтруїзму волонтерівмедиків стає можливим в умовах самореалізації інноваційно-дослідного потенціалу особистості, розвитку почуття власної гідності, емоційної чутливості.

\section{ЛІТЕРАТУРА}

1. Балашов С.М. Особливості самореалізації студентів у міжнародних волонтерських програмах : диссертация ... кандидата психологических наук: 19.00 .01 /С.М. Балашов. - Острог, 2013. - 228 с.

2. Власенко Ю.А. Психологическая феноменология инновационного потенциала личности /Ю.А. Власенко // Наука і освіта. - 1998. - № 4-5. - С. 41-45.

3. Закон України „Про волонтерську діяльність” від 19 квітня 2011 року № 5073 - VI [Електронний ресурс]. - Режим доступу: http://zakon4.rada.gov.ua/laws/show/3236-175073.

4. Ильин Е.П. Дифференциальная психология профессиональной деятельности / Е.П. Ильин. - СПб: Питер, 2008. $432 \mathrm{c}$.

5. Основы психодиагностики: Практикум / ред. Л.Д. Столяренко. - Ростов Н/д: «Феникс», 2003. - 704 с.

6. Психодиагностическое познание профессиональной деятельности: Учебн. пособие / сост. В.А. Сонин. - СПб: Речь, 2004. - 408 c.

7. Собчик Л.Н. Психология индивидуальности. Теория и практика психодиагностики / Л.Н. Собчик. - СПб: Речь, 2003. $-624 \mathrm{c}$.

\section{REFERENCES}

1. Balashov E.M. Osoblyvosti samorealizatsii students at the international Volunteer programs: the dissertation ... The candidate of psychological sciences: 19.00.01 / E.M. Balashov. - Ostrog, 2013. - 228 p. 2. Vlasenko Y.A. Psychological phenomenology of the innovative potential of personality / Y.A. Vlasenko //Science and Society. - 1998. № 4-5.- P. 41-45.

3. Law of Ukraine "About volunteerism" for 19 quarters of 2011 to No. 5073 - VI [Electron resource]. - Access mode: http://zakon4.rada.gov.ua/laws/show/3236-175073.

4. Ilyin E.P. Differential psychology of professional activity /E.P. Ilyin. - St. Petersburg: Peter, 2008. - 432 p.

5. Foundations of psychodiagnostics: Workshop /V.A. Stolyarenko. - Rostov N/A: "Phoenix", 2003. - 704 p.

6. Psychodiagnostic knowledge of professional activity: Teaching. allowance / comp. V.A. Sonin. - SPb: Speech, 2004. - 408 p.

7. Sobchik L.N. Psychology of individuality. Theory and practice of psychodiagnostics / L.N. Sobchik. - SPb: Speech, 2003. - 624 p.

\section{Research of psychological determinants of altruism of volunteers- medic}

\section{K. A. Talalayev, N. V. Krivtsova, I. V. Brynza}

Abstract. The article presents the results of the theoretical and empirical research of psychological determinants of altruism of volunteers-physicians. The study proposes a modeling method. The analysis of the models allowed to reveal the leading psychological determinants of natural altruism, among which: self-esteem and research instinct, non-leading psychological determinants were: an intensive-transformative type of behavior in an innovative situation, meaningful-intensive type of implementation of various innovative capabilities and a labile type of person's behavior.

Keywords: volunteer activity, altruistic instinct, sense of dignity, research instinct, self-realization of innovative research potential of personality.

\section{Исследование психологических детерминант альтруизма волонтеров-медиков}

К. А. Талалаев, Н. В. Кривцова, И. В. Брынза

Аннотация. В статье представлены результаты теоретико-эмпирического исследования психологических детерминант альтруизма волонтеров-медиков. В исследовании предложен метод моделирования. Анализ полученных моделей позволил выявить ведущие психологические детерминанты природного альтруизма, среди которых: чувство собственного достоинства и исследовательский инстинкт, а не ведущими психологическими детерминантами оказались: интенсивноепреобразовательный тип поведения в инновационной ситуации, осмысленно-интенсивный тип реализации различных инновационных возможностей и лабильный тип поведения личности.

Ключевые слова: волонтерская деятельность, альтруистический инстинкт, чувство достоинства, исследовательский инстинкт, самореализация инновационно-исследовательского потенциала личности. 
Editor-in-chief: Dr. Xénia Vámos

The journal is published by the support of Society for Cultural and Scientific Progress in Central and Eastern Europe

Készült a Rózsadomb Contact Kft nyomdájában.

1022 Budapest, Balogvár u. 1.

www.rcontact.hu 